Maurer School of Law: Indiana University

Digital Repository@ Maurer Law

Indiana Law Journal

Volume 88 | Issue 1

Article 4

Winter 2013

\title{
Competition and Crisis in Mortgage Securitization
}

Michael Simkovic

Seton Hall University School of Law, michael.simkovic@shu.edu

Follow this and additional works at: https://www.repository.law.indiana.edu/ilj

Part of the Banking and Finance Law Commons, and the Housing Law Commons

\section{Recommended Citation}

Simkovic, Michael (2013) "Competition and Crisis in Mortgage Securitization," Indiana Law Journal: Vol. 88 : Iss. 1 , Article 4.

Available at: https://www.repository.law.indiana.edu/ilj/vol88/iss1/4

This Article is brought to you for free and open access by the Law School Journals at Digital Repository @ Maurer Law. It has been accepted for inclusion in Indiana Law Journal by an authorized editor of Digital Repository @ Maurer Law. For more information, please contact rvaughan@indiana.edu.

\section{$\Psi$}

JEROME HALL LAW LIBRARY

INDIANA UNIVERSITY

Maurer School of Law
Blooming ton 


\title{
Competition and Crisis in Mortgage Securitization
}

\begin{abstract}
MiCHAEL SiMKOVIC*
U.S. policy makers often treat market competition as a panacea. However, in the case of mortgage securitization, policy makers' faith in competition is misplaced. Competitive mortgage securitization has been tried three times in U.S. historyduring the 1880s, the 1920s, and the 2000s-and every time it has collapsed. Most recently, competition between mortgage securitizers led to a race to the bottom on mortgage underwriting standards that ended in the late 2000s financial crisis. This Article provides original evidence that when competition was less intense and securitizers had more buyer power, securitizers acted to monitor mortgage originators and to maintain prudent underwriting. However, securitizers' ability to monitor originators and maintain high standards was undermined as competition shifted power away from securitizers and toward originators. Although standards declined across the market, the largest and most powerful of the mortgage securitizers, the Government Sponsored Enterprises (GSEs), remained more successful than other mortgage securitizers at maintaining prudent underwriting. This Article proposes reforms based on lessons from the recent financial crisis: merge the GSEs with various government agencies' mortgage operations to create a single dedicated mortgage securitization agency that would seek to maintain market stability, improve underwriting, and provide a long-term investment return for the benefit of taxpayers.
\end{abstract}

INTRODUCTION 214

I. A HiSTORY OF MARKET FAILURES AND GOVERNMENT RESCUES .........................216

II. COMPETITION, SuPPLIER POWER, AND THE RACE TO THE BOTTOM ......................222

A. MORTGAgE UNDERWRITING DETERIORATED FROM 2004 TO 2007 ..........225

B. GSES HiSTORICALLY MONITORED AND DiSCIPLINED ORIGINATORS .......232

C. ORIGINATORS CONSOLIDATED AND DIVERSIFIED AWAY FROM

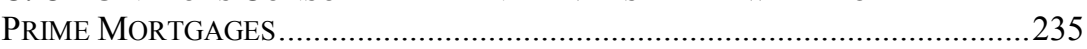

D. SECURITIZERS COMPETED FOR MARKET SHARE BY RELAXING

STANDARDS...

$\dagger$ Copyright (C) Michael Simkovic 2013.

* Associate Professor, Seton Hall University School of Law. Msimkovic@gmail.com. This Article won the 2012 American College of Consumer Financial Services Lawyers writing competition. Thanks go to Cynthia Furmanek, Timothy Malacrida, Jason Mushnick, and William Pugh for outstanding research support. Thanks also go to Professors Vicki Been, Susan Block-Lieb, Ryan Bubb, David G. Carlson, Amedeo DeCesari, Kathleen Engel, Linda Fisher, Timothy Glynn, Dwight M. Jaffee, Edward Janger, Kristin Johnson, Edward J. Kane, Robert Lawless, Adam Levitin, Stephen J. Lubben, Ronald J. Mann, Robert J. Martin, Saule Omarova, Chrystin Ondersma, Frank Pasquale, Jon Romberg, David Reiss, Michael Risinger, Adam Steinman, Charles Sullivan, Susan Wachter, Arthur Wilmarth, Yesha Yadav, to the Seton Hall Faculty Colloquium and participants in the Canadian Law and Economics Association conference and American Association of Law Schools conference for helpful comments and suggestions, to the American College of Consumer Financial Services Lawyers, and to IMF researchers Narayan Suryakumar and Rebecca McCaughrin for sharing data and related assistance. 
E. POWER SHIFTED FROM GSES TO ORIGINATORS …....................................239

F. GSE UNDERWRITING REMAINED MORE CONSERVATIVE THAN

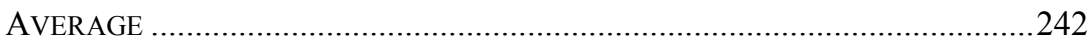

G. EXPERTS BELIEVE THAT COMPETITION CONTRIBUTED TO LOOSE

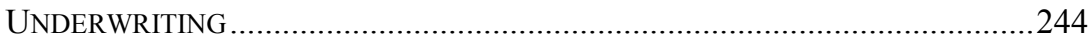

III. CONCENTRATED MARKET StRUCTURES WORK WELL IN OTHER COUNTRIES ....246

IV. MORTGAGE MARKET PRIVATIZATION INCREASES RISKS TO TAXPAYERS............249

A. Private Competition Leads to More FaIlures and “Bailouts" ....250

B. LENDER-OF-LAST-RESORT PROGRAMS TRANSFER CYCLICAL

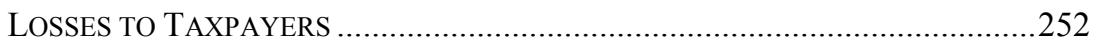

C. REINSURANCE ADDS AGENCY COST AND COMPLEXITY …......................256

V. GOVERNMENT PRESSURE PROBABLY DID Not DRIVE LOOSE UNDERWRITING ...257

A. INDUSTRY HAS SOUGHT TO DEFEND ITSELF BY BLAMING

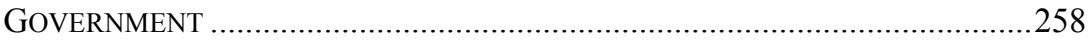

B. THERE Is NO EVIDENCE THAT THE COMMUNITY REINVESTMENT ACT

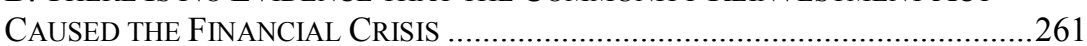

C. "SYNTHETIC" COLlateralized DEBT OBLIGATIONS (CDOS)

SUGGEST THAT RISK TAKING WAS MARKET DRIVEN ………………............262

D. Mortgage Lenders LobBIED AgAInSt SAFE-LENDING

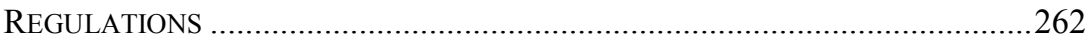

E. HUD AFFordable Housing GoAls Played AT Most A LIMITED

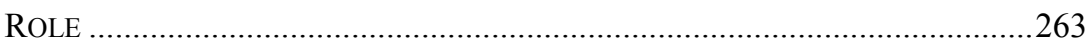

VI. DodD-Frank Regulation MAy Not Be ENOUgh to Prevent ANOther

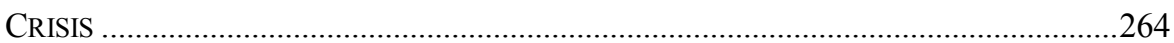

A. HIGH-RISK LOANS CAN STILL BE ORIGINATED ......................................2264

B. Compensation CAN STILl CREATE PERVERSE InCENTIVES ......................265

C. REGULATORS REMAIN VULNERABLE AND UNDERFUNDED ........................266

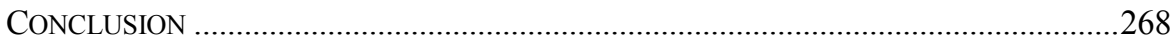

\section{INTRODUCTION}

U.S. policy makers often assume that market competition is a panacea. This faith in competition motivates proposals by the U.S. Department of Treasury (the "Treasury") to radically transform the U.S. residential mortgage market. However, in the case of mortgage securitization, policy makers' faith in competition ${ }^{1}$ is misplaced. Competitive mortgage securitization has been tried three times in U.S. history - during the $1880 \mathrm{~s}$, the $1920 \mathrm{~s}$, and the $2000 \mathrm{~s}$ - and every time it has collapsed in a destructive financial and economic crisis. ${ }^{2}$

Securitization is a method of financing whereby loan receivables or other cash flows are bundled into securities and sold to investors. ${ }^{3}$ Mortgage securitization

1. See infra notes $139-45$ and accompanying text.

2. See infra Figures 1-3; notes 14-30 and accompanying text.

3. See Susan Block-Lieb \& Edward J. Janger, Reforming Regulation in the Markets for Home Loans, 38 FordhAM URB. L.J. 681, 688-90 (2010); Kenneth C. Kettering, Securitization and Its Discontents: The Dynamics of Financial Product Development, 29 CArdozo L. Rev. 1553, 1569-74 (2008); Stephen J. Lubben, Beyond True Sales: Securitization and Chapter 11, 1 N.Y.U. J.L. \& Bus. 89, 92-96 (2004); Steven L. Schwarcz, 
divides lending into four functions generally handled by four different types of specialized financial institutions: origination, the initial step of making loans to individual borrowers; servicing, managing the ongoing relationship with individual borrowers and collecting payments; securitization, buying large numbers of loans from originators and packaging those loans into investments that can be sold to investors; and funding, buying mortgage backed securities (MBS) from securitizers and holding them in portfolio as an investment.

Securitization can provide a long-term source of funding and thereby reduce financial institutions' exposure to fluctuations in prevailing interest rates. Traditional depository institutions fund long-term fixed rate mortgages with shortterm deposits. Because of the duration mismatch, if interest rates increase, depository institutions face rising funding costs and declining loan portfolio values. Securitization can transfer interest rate risk from financial institutions to professional fixed income investors. Indeed, securitization reemerged in the United States shortly after the devastation caused by the rising interest rate environment of the late 1970 s and early 1980 s.

Securitization can also be used to transfer the loan-specific risk that borrowers will default or fail to repay their loans. After securitization, institutions that originate or service mortgages will generally have the best information about mortgage default risk because originators may have collected private information about borrowers during their initial intake and because servicers are the first to know about delinquent payments. However, investors with less information about default risk and less expertise in the mortgage market will bear much of that default risk. ${ }^{4}$ That is, unless an extremely well-capitalized financial institution or the government fully guarantees the underlying mortgages.

In the mid-2000s, competition between mortgage securitizers for loans led to deteriorating mortgage underwriting standards and a race to the bottom that ended in the late 2000s financial crisis. ${ }^{5}$ Underwriting prevents losses at the front end by basing loan approval decisions and lending terms on data-driven predictions of the likelihood of default, or failure to repay, and the severity of losses to lenders in the event of default. Loose underwriting involves making loans that are likely to default.

This Article provides evidence that when competition was less intense and securitizers had more buyer power, securitizers acted to monitor mortgage originators and to maintain prudent underwriting. ${ }^{6}$ However, securitizers' ability to monitor originators and maintain high standards was undermined as competition shifted buyer power away from securitizers and consolidation increased originators' supplier power. ${ }^{7}$ These changes in market structure and market power match the specific timing of the dramatic deterioration in underwriting standards

The Alchemy of Asset Securitization, 1 Stanford J.L. Bus. \& Fin. 133, 135-36 (1994); Michael Simkovic, Secret Liens and the Financial Crisis of 2008, 83 AM. BANKR. L.J. 253, 284-88 (2009) [hereinafter Simkovic, Secret Liens].

4. See Dan Immergluck, Foreclosed: High-Risk Lending, Deregulation, and the Undermining OF AMERICA's MORTGAge MARKet 99-111 (2009); Kathryn Judge, Fragmentation Nodes: A Study in Financial Innovation, Complexity, and Systemic Risk, 64 STAN. L. REV. 657, 690-93 (2012).

5. See infra Part III.A.

6. See infra Part III.B.

7. See infra Part III.C-E. 
and vintage loan performance in the mid-2000s that contributed to the crisis. ${ }^{8}$ Furthermore, although standards declined across the market, the largest and most powerful of the mortgage securitizers, the Government Sponsored Enterprises (GSEs), remained more successful than other mortgage securitizers at maintaining prudent underwriting. ${ }^{9}$

Competitive pressures exacerbated private financial institutions' strong incentives to take risks. ${ }^{10}$ Whereas private investors and managers capture most of the upside of mortgage lending, taxpayers bear much of the downside risk because of the cyclicality of default risk, limited liability, and public safety nets. ${ }^{11}$ Because financial institution bailouts are routine, private financial institutions rationally prefer to take more risk than is optimal for taxpayers while government agencies rationally prefer to limit risk. ${ }^{12}$

These findings have profound implications for post-crisis reform of U.S. residential mortgage finance. This Article concludes that, notwithstanding recent financial regulation reforms, fragmentation of the mortgage securitization market may still lead to greater risk taking by mortgage originators, future public bailouts of private financial institutions may be inevitable, and a reprivatized, fragmented securitization market could ultimately prove more dangerous to taxpayers than the post-crisis status quo of de facto government monopoly. ${ }^{13}$ Though not definitive, the evidence presented in this Article raises serious concerns that should be addressed before the Treasury proceeds with radical reform of U.S. housing finance.

This Article proposes reforms based on lessons from the recent financial crisis and the United States' successful and stable post-WWII mortgage market. Because securitizer buyer power is an important determinant of stability and prudent underwriting, buyer power should be increased by merging the GSEs with various government agencies' mortgage operations to create a single, dedicated mortgage securitization agency that would seek to maintain market stability, improve underwriting, and provide a long term investment return for the benefit of taxpayers.

\section{A HiSTORY OF MARKET FAILURES AND GOVERNMENT RESCUES}

Private investors have not been very successful at evaluating the complex risks associated with pools of mortgages. Unlike equities, which announce their riskiness to investors by virtue of their first-loss position in corporate capital structures, mortgage securitization promises investors the safety of secured lending against sound collateral. However, each of the three times competitive mortgage securitization by competing private financial institutions has been tried, it delivered much higher risk levels than investors expected, and each time the market ultimately collapsed. An early form of private mortgage securitization was tried in

8. See infra Part III.A.

9. See infra Part III.F.

10. See infra Part V.A.

11. See infra Part V.B.

12. See infra Parts V-VI.

13. See infra Part VII. 
the late $1800 \mathrm{~s}$ and failed in the $1890 \mathrm{~s} .{ }^{14}$ Another variation on private mortgage securitization failed in the late $1920 \mathrm{~s}^{15}$ Whereas equity markets have survived periodic boom and bust cycles and investors tolerate losses and still reinvest in equities, competitive mortgage securitization effectively disappeared from U.S. housing finance for decades after each of its two previous failures. The fragility of mortgage markets has contributed to a perceived need for increased public oversight and support.

Mortgage securitization first emerged in the western United States in the late 1800 s to finance farm mortgages. ${ }^{16}$ Prior to securitization, farm mortgages were financed through a process called "mortgage brokerage," which connected western borrowers with northeastern and European investors. ${ }^{17}$ Mortgage brokers with offices in rural areas originated, serviced, and then sold individual farm mortgages to investors. ${ }^{18}$ Investors reviewed and could accept or reject each individual loan. ${ }^{19}$

Because loans were individually reviewed by investors, mortgage brokerage provided credit to only the most creditworthy borrowers who borrowed under standard terms. However, underwriting standards became more flexible and credit more widely available to higher risk borrowers once mortgage brokers developed an early form of securitization (modeled on structures that had been used in Europe).$^{20}$ These early securitizations were structured as trusts that owned a few hundred mortgages and that issued debentures (or bonds) to investors. ${ }^{21}$ The trusts were simple pass-through entities that allowed for risk pooling and diversification. ${ }^{22}$ Investors generally did not review individual mortgages, relying instead on the good reputations and creditworthiness of the mortgage companies that organized the trusts. ${ }^{23}$ Unlike in Europe, regulation of U.S. securitizations was minimal, and over time, underwriting standards and the quality of the collateral

14. Kenneth A. Snowden, Mortgage Companies and Mortgage Securitization in the Late Nineteenth Century 31-32 (Aug. 2007) (unpublished manuscript) [hereinafter Snowden, Mortgage], available at http://www.uncg.edu/bae/people/snowden/Wat_jmcb_aug07.pdf.

15. William N. Goetzmann \& Frank Newman, Securitization in the 1920's 1 (Nat'l Bureau of Econ. Research, Working Paper No. 15650, 2010), available at http://www.nber.org/papers/w15650; Kenneth A. Snowden, The Anatomy of a Residential Mortgage Crisis: A Look Back to the 1930s 11-12 (Nat'l Bureau of Econ. Research, Working Paper No. 16244, 2010) [hereinafter Snowden, Anatomy], available at http://www.nber.org/papers/w16244.

16. Snowden, Mortgage, supra note 14, at 1.

17. Id. at 3-4.

18. See Snowden, Mortgage, supra note 14, at 4-5.

19. Id. at 5-6.

20. Id. at 1, 3 ("[D]ebentures offered a low-cost mechanism for marketing loans that were too risky, or non-standard in form, to be brokered.").

21. Id. at 9 .

22. Id. at 9-13. By contrast, private securitization in the late twentieth century was more complex because investors could invest in different tranches, which carried different risk levels based on a system of priorities for cash flows from the mortgage pool. Id. at 11; IMMERGLUCK, supra note 4, at 34-41.

23. Snowden, Mortgage, supra note 14, at 14-16. 
deteriorated. ${ }^{24}$ Many abuses were documented, including the use of already defaulted mortgages as collateral. ${ }^{25}$ After a financial crisis devastated many of the western mortgage companies in the 1890s, private mortgage securitization largely disappeared from the United States for several decades. ${ }^{26}$

Private mortgage securitization returned in the 1910s and 1920s, this time in an urban context, as northeastern title insurance companies began to insure against mortgage default, place those insured mortgages into trust accounts, and sell investors participation certificates backed by the pools of insured mortgages. ${ }^{27}$ As with mortgage securitization in the late 1800s, investors focused on the creditworthiness of the financial institutions that organized the mortgage pool-in this case, the title insurance companies - rather than the individual loans. ${ }^{28}$ As in the $1800 \mathrm{~s}$, the quality of the underlying collateral was problematic, fraud was endemic, and the insurance companies proved to be too thinly capitalized to make good on their guarantees amid high defaults. ${ }^{29}$ During the late 1920 s and early 1930 s, the secondary mortgage market again collapsed. ${ }^{30}$

After the second failure of private mortgage securitization and the Great Depression, the U.S. government started to play a more active role in housing finance-bearing credit risk, allocating capital, and-under very limited circumstances - originating loans. The federal government bore credit risk by insuring mortgages through the Federal Housing Administration (FHA), established in $1934 ;^{31}$ the Department of Veterans Affairs (VA) loan guarantee program, established in 1944; ${ }^{32}$ and the Farmers Home Administration (FmHA), established in $1946{ }^{33}$ The government also bore credit risk by buying mortgages through the Federal National Mortgage Association ("Fannie Mae"), originally established as a division of the government in $1938 .{ }^{34}$ A government agency originated a very large

24. Id. at 27-30; Housing Finance Reform: Should There Be a Government Guarantee? Before the S. Comm. on Banking, Hous., and Urban Affairs, 112th Cong. at 5-7 (2011) [hereinafter Housing Finance Reform].

25. Snowden, Mortgage, supra note 14, at 31-32, 48 n.55.

26. Id. at 31-32.

27. Housing Finance Reform, supra note 24, at 54-55 (statement of Adam J. Levitin, Professor of Law, Georgetown University Law Ctr.). Scholars have also identified other structures used in the 1920s as forerunners of modern securitization, but the structure used by title insurance companies probably bears the closest resemblance to modern securitization.

28. Id.

29. Id.

30. Id.; Snowden, Anatomy, supra note 15, at 11-19.

31. Fred Wright, The Effect of New Deal Real Estate Residential Finance and Foreclosure Policies Made in Response to the Real Estate Conditions of the Great Depression, 57 Ala. L. REv. 231, 251 (2005).

32. Bernard P. Ingold, The Department of Veterans' Affairs Home Loan Guaranty Program: Friend or Foe?, 132 MiL. L. REV. 231, 232-33 (1991).

33. Susan A. Schneider, Financing the Agricultural Operation: Recent Developments and Current Trends, 4 DraKe J. AGRIC. L. 215, 230 (1999).

34. Robert Higgs, Cumulating Policy Consequences, Frightened Overreactions, and the Current Surge of Government's Size, Scope, and Power, 33 HaRV. J.L. \& PuB. PoL'y 531, 539 (2010). 
number of mortgage loans during the Great Depression, ${ }^{35}$ but the government rarely originates loans today. ${ }^{36}$

Fannie Mae was privatized in 1968 to shrink the federal government's balance sheet, although it was generally assumed by investors that the federal government would rescue Fannie Mae if it ever became insolvent. ${ }^{37}$ Because of its origins as a government agency, Fannie Mae is referred to as a GSE and its securities are sometimes referred to as "Agency" securities. In 1970, a similar GSE, the Federal Home Loan Mortgage Corporation ("Freddie Mac"), was created to serve a slightly different set of mortgage originators and to compete with Fannie Mae. ${ }^{38}$ After the privatization of Fannie Mae in 1968, the government continued to directly bear credit risk by guaranteeing mortgage-backed securities through another government agency, the Government National Mortgage Association ("Ginnie Mae"). ${ }^{39}$ The government allocates capital through laws, regulations, and policies that limit eligibility for government mortgage programs and set credit standards and pricing. ${ }^{40}$

Large-scale private mortgage securitization by non-GSEs reemerged in the early 1980 s. $^{41}$ In the mid-2000s, competition between mortgage securitizers-large investment banks, commercial banks, and the GSEs-intensified, with non-GSE securitization overtaking GSE securitization in $2005 .{ }^{42}$ After extremely high default rates for securitized subprime mortgages, private non-GSE securitization collapsed in late 2007 and early $2008 .^{43}$ The U.S. government provided low cost capital, guarantees, and other public support to both GSEs and large non-GSE securitizers. The GSEs were effectively renationalized in September of 2008, while other

35. Snowden, Anatomy, supra note 15, at 21-22 ("[The Home Owners' Loan Corporation opened] 400 offices throughout the country and employ[ed] a staff of 20000 to process loans and appraise properties. In only three years the agency received applications from 40 percent of all residential mortgagors and wrote new loans on ten percent of the owner-occupied homes in the U.S.").

36. There is one notable exception. The government lends directly for purchase, construction, or improvement of homes on Native American trust land through the Department of Veterans Affairs. John McGee Ingram, Home Ownership Opportunities in Indian Country, 7 J. AfFordable Housing \& Community Dev. L. 164, 174 (1998).

37. Company Overview, FANNIE MAE, http://www.fanniemae.com/kb/index?page=home\&c=aboutus; see also Krishna Guha, Saskia Scholtes \&James Politi, Saviours of the Suburbs; But Are America's Two Main Home Lenders at Risk?, Fin. TIMES, June 4, 2008, at 9.

38. Freddie Mac was created by the government as a private company. Company Profile, FREDDIE MAC, http://www.freddiemac.com/corporate/company_profile/; Guha et. al, supra note 37.

39. About

Ginnie

Mae,

GINNIE

MAE, http://www.ginniemae.gov/about/history.asp?subTitle=About. Ginnie Mae is backed by the full faith and credit of the U.S. government. Id. Technically, Ginnie Mae does not actually securitize mortgages; it guarantees MBS comprised of loans insured by the FHA or guaranteed by the VA. Id.

40. See Peter P. Swire, The Persistent Problem of Lending Discrimination: A Law and Economics Analysis, 73 TEX. L. REV. 787, 845 (1995).

41. See infra Figure 2.

42. See infra Figure 2.

43. See infra Figures 2, 6. 
[Vol. 88:213

financial institutions remained privately owned. ${ }^{44}$ The recent mortgage crisis is at least the third failure of private mortgage securitization in U.S. history. Figures 1, 2 , and 3 below document the almost complete collapse of private mortgage securitization.

Figure 1 shows that mortgage lending fell sharply during the crisis and that the few mortgages that were being originated increasingly depended on securitization as a source of funding. The columns are scaled to the left axis and show mortgage origination volume plummeting in 2007 and 2008. Origination volume remained at low levels through 2010. The line, scaled to the right axis, shows the percent of originated mortgages that were funded through securitization skyrocketing starting in 2007 , reaching roughly $85 \%$ by 2009 .

Figure 1: While home mortgage origination volume has fallen to below 2001 levels, securitization rates have climbed to record highs since 2008

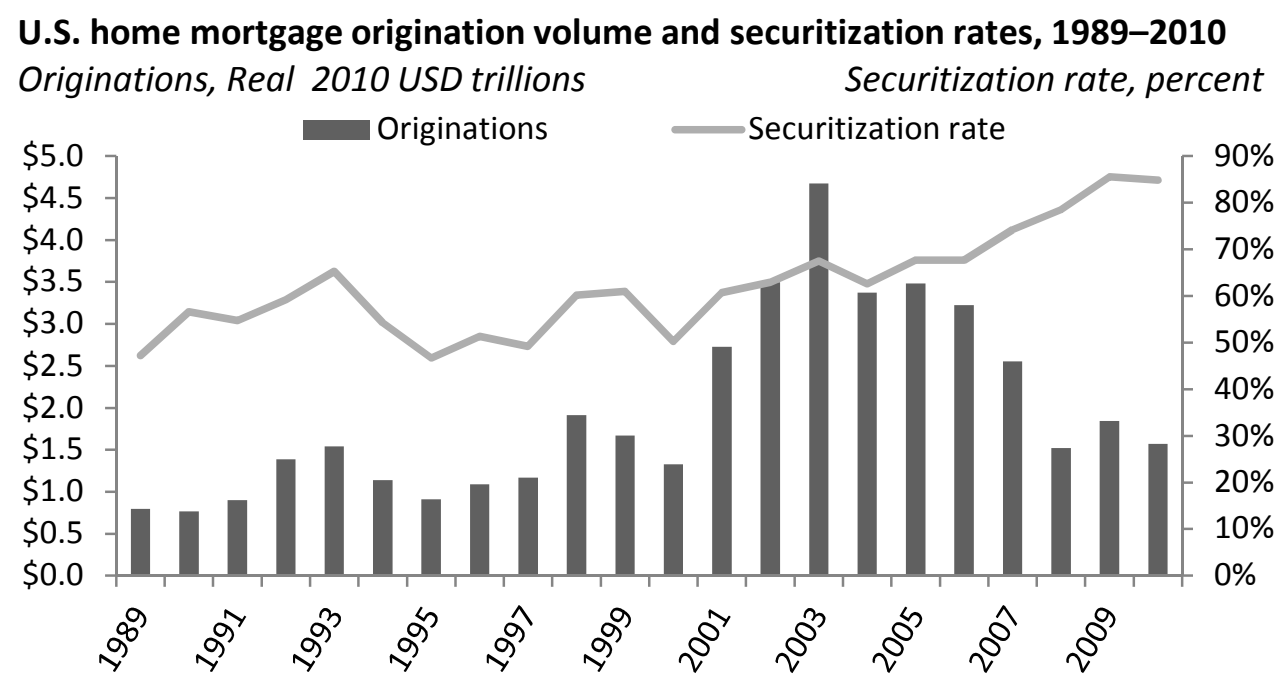

Note: Total MBS figures used to calculate securitization rates excludes re-securitizations, scratch-anddent MBS and deals backed by seasoned loans.

Source: 2011 Mortgage Market Statistical Annual, Vol. 2, p. 3-6; Inside MBS \& ABS; Bureau of Labor

44. In September 2008, the Federal Housing Finance Agency (FHFA) became the conservator of the GSEs. In connection with the conservatorship, the Treasury committed to fund any shortfalls in their net worth. Edward J. DeMarco, FHFA, A Strategic Plan for Enterprise Conservatorships: The NeXt Chapter in a Story that Needs an Ending 5 (2012). 
Figure 2 shows that private securitization almost completely disappeared after the crisis and the secondary market came to depend on government support. The line, scaled to the left axis, shows the volume of mortgage backed securities issuance - the total secondary market size. The area chart, scaled to the right axis, shows the relative market share of the GSEs and federal government agencies ("Agency") versus private label securitizers ("Nonagency"). The percent of securitized mortgages that were securitized or guaranteed by Agencies is represented by the lighter shade at the bottom, and the percent of securitized mortgages that were securitized by private label securitizers is represented by the darker shade at the top. The chart shows Agency market share declining slowly through 2003, then plummeting in the mid-2000s, and then shooting up after the crisis in 2008 and beyond. By 2008, Agency share exceeded 95\% of the market. In other words, in the post-crisis environment, almost all secondary market issuance was conducted through agencies affiliated with the federal government.

Figure 2: After the financial crisis, GSE/Agency market share of mortgage securitization shot up to $\mathbf{9 5 \%}$, the highest government share in twenty years

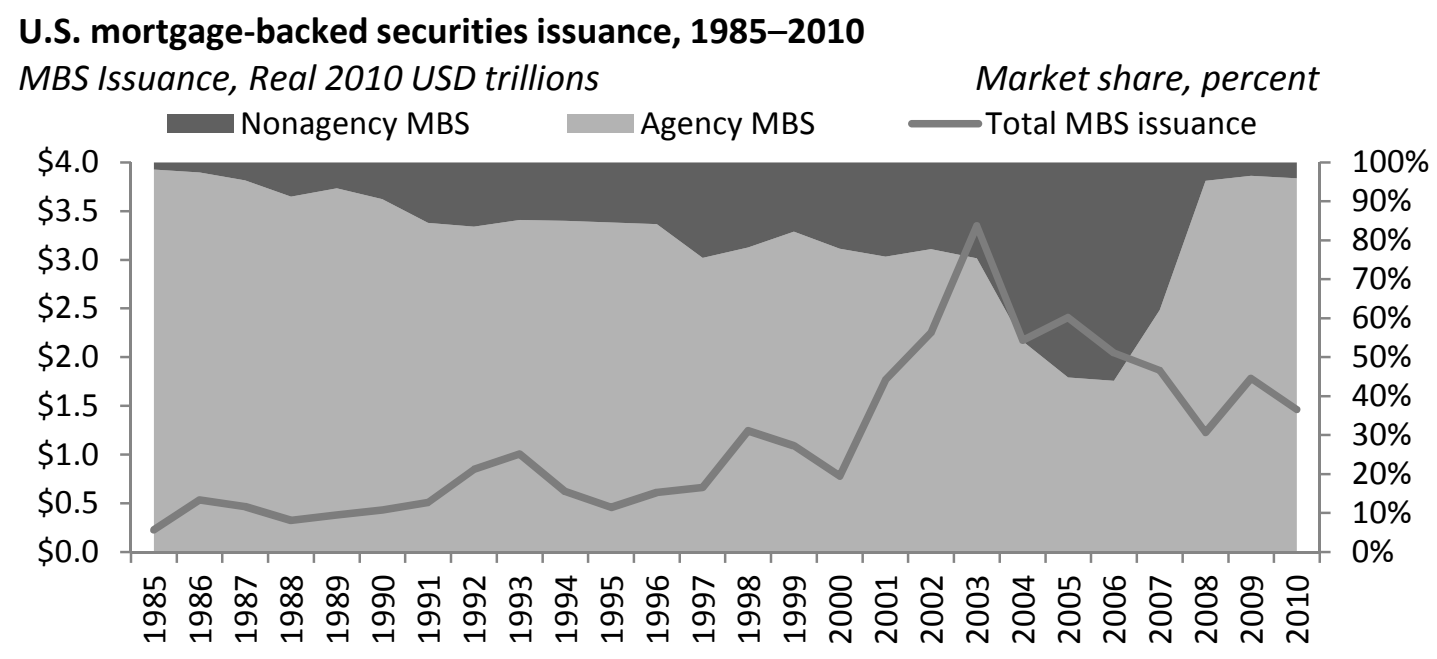

Note: Agency MBS issuance includes GNMA, FHLMC, and FNMA.

Source: FDIC, A New Plateau for the U.S. Securitization Market, Chart 2; Inside MBS \& ABS; GNMA, FHLMC, FNMA.; 2011 Mortgage Market Statistical Annnual, Vol. 2, p. 9.; Bureau of Labor Statistics. 
Figure 3 shows who ultimately purchased mortgage backed securities during and after the crisis. Whereas most investors were shedding mortgage backed securities from 2007 on, the Treasury and Federal Reserve dramatically increased their holdings. Government-affiliated agencies were not only securitizing mortgages and selling MBS - they were also buying MBS to prop up the market.

Figure 3: The Federal Reserve and Treasury have dramatically increased MBS purchases while most private investors stopped buying MBS

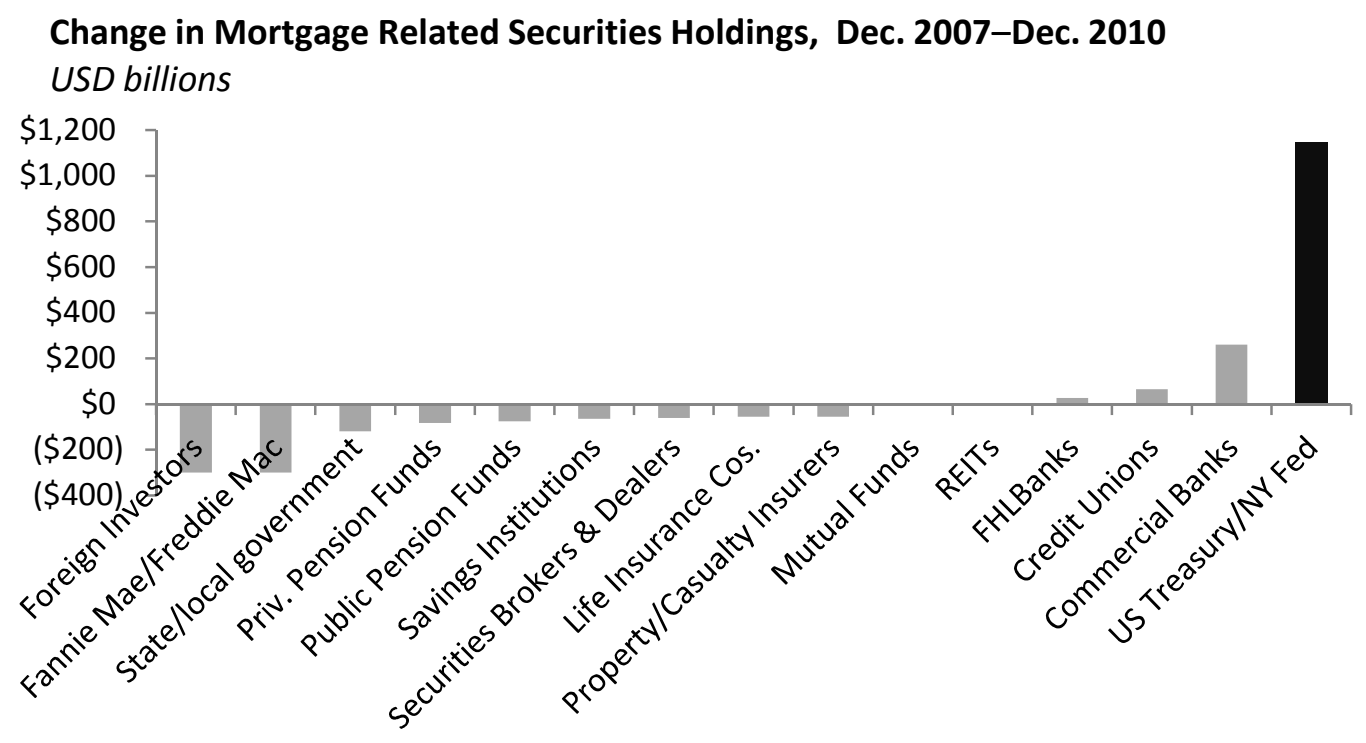

Note: NY Fed and Treasury MBS holdings consist of Agency MBS.

Source: 2011 Mortgage Market Statistical Annual, Vol. 2, p. 293; Inside MBS \& ABS.

\section{COMPetition, Supplier Power, AND THE RACE TO THE BOTTOM}

As discussed in greater detail below, the Treasury and a number of experts have expressed concern about the extent of government involvement in mortgage finance and would like to restore a competitive, private market. However, the role of competition as a contributing cause of the mortgage crisis suggests that privatization could lead to instability and future losses for taxpayers.

Traditional economic theory generally suggests that greater competition between financial institutions leads to more risk taking and more frequent financial crises. ${ }^{45}$ To explain this inverse relation between stability and competition, scholars

45. See Thorsten Beck, Asli Demirgüç-Kunt \& Ross Levine, Bank Concentration and Fragility: Impact and Mechanics, in The Risks of FinANCIAL InSTITUTIONS 193, 193-94 (Mark S. Carey \& René M. Stulz eds., 2006); Elena Carletti, Competition and Regulation in Banking, in HANDBOOK OF FINANCIAL INTERMEDIATION AND BANKING 449, 450-51 (Anjan 
have proposed several possible mechanisms of action. According to the "franchise value" hypothesis, increased competition reduces the profitability and value of financial institutions and encourages their managers to take greater risks to try to increase returns. ${ }^{46}$ According to the screening hypothesis, increased competition undermines financial institutions' ability to screen borrowers, because the institution may not wish to invest as much in screening borrowers who may ultimately take their business elsewhere and because the institution will have less information about borrowers who deal with multiple institutions. ${ }^{47}$ At least one theoretical paper has suggested that in a fragmented, competitive mortgage market, the underpricing of mortgage risk may be inevitable. ${ }^{48}$ The traditional view that competition reduces stability is supported by empirical studies of the United States and a handful of other countries. ${ }^{49}$

V. Thakor \& Arnoud W. A. Boot eds., 2008) (arguing that an increase in the number of competitors undermines bank screening tests for borrower creditworthiness); Thomas F. Hellmann, Kevin C. Murdock \& Joseph E. Stiglitz, Liberalization, Moral Hazard in Banking, and Prudential Regulation: Are Capital Requirements Enough?, 90 AM. ECoN. REV. 147, 147-49 (2000) (arguing that reduced competition and greater profits create "franchise value" that reduces banks' incentives to take risks and thereby reduces financial system fragility); Michael C. Keeley, Deposit Insurance, Risk, and Market Power in Banking, 80 AM. ECON. REv. 1183, 1183-85 (1990) (finding that the surge of bank failures in the United States during the 1980s was caused by deregulation and market pressures that reduced banks' monopoly rents and incentivized greater risk taking); Carmen Matutes \& Xavier Vives, Imperfect Competition, Risk Taking, and Regulation in Banking, 44 EuR. ECon. Rev. 1, 2-4 (2000); Allen N. Berger, Leora F. Klapper \& Rima Turk-Ariss, Bank Competition and Financial Stability 1 (World Bank, Working Paper No. 4696, 2008), available at $\mathrm{http}: / / \mathrm{ssrn}$.com/abstract=1243102 ("Under the traditional 'competition-fragility' view, more bank competition erodes market power... This encourages banking organizations to take on more risk to increase returns.").

46. Hellmann et al., supra note 45 , at 148 .

47. Carletti, supra note 45, at 461-63.

48. Andrey Pavlov \& Susan M. Wachter, The Inevitability of Marketwide Underpricing of Mortgage Default Risk, 34 REAL Est. ECON. 479, 479-80 (2006).

49. ORg. FOR ECON. Co-Operation \& Dev., COMPETITION, CONCENTRATION AND STABILITY IN THE BANKING SECTOR 17-32 (2010), available at http://www.oecd.org/dataoecd/52/46/46040053.pdf; Franklin Allen \& Douglas Gale, Competition and Financial Stability, 36 J. Money, CRediT \& BANKING 453, 453-80 (2004) (finding that concentration increases stability); Carletti, supra note 45, at 450-51; Hellmann et al., supra note 45, at 147-65; Keeley, supra note 45, at 1183-98; Michael D. Bordo, Hugh Rockoff \& Angela Redish, A Comparison of the United States and Canadian Banking Systems in the Twentieth Century: Stability vs. Efficiency? (Nat'l Bureau of Econ. Research, Working Paper No. 4546, 1993), available at http://ssrn.com/abstract=288470 (arguing that from 1920 to 1980 , the more concentrated Canadian banking system was more profitable, more efficient, and more stable than the less concentrated U.S. banking system); Zuzana Fungacova \& Laurent Weill, How Market Power Influences Bank Failures: Evidence from Russia (Bank of Fin. \& Université de Strasbourg, Discussion Paper, 2009), available at http://ssrn.com/abstract=1343173 (finding that for Russian banks from 2001 to 2007, competition as measured by the Lerner Index reduced financial system stability); Gabriel Jiménez, Jose A. Lopez \& Jesús Saurina, How Does Competition Impact Bank Risk-Taking? (Fed. Reserve Bank of S.F., Working Paper No. 2007-23, 2007), available at $\mathrm{http} / /$ www.frbsf.org/publications/economics/papers/2007/wp07-23bk.pdf (finding that less competition as measured by the Lerner Index is associated with better loan performance for Spanish banks). 
The traditional view, though still dominant, has been challenged by some studies of select non-U.S. markets and by studies that measure competition using alternate measures such as barriers to entry, pricing, and profit margins. ${ }^{50}$ These varied results suggest that it may be risky to generalize about the impact of competition and that specific financial markets should be studied individually in depth. Because of the importance of definitional and contextual issues, ${ }^{51}$ this Article will limit its analysis to the impact of competition, defined with respect to market concentration, in the specific institutional context of the U.S. residential mortgage securitization market.

Although many of the traditional studies of competition and underwriting have focused on competition between vertically integrated financial institutions, similar dynamics may be at work in the context of mortgage securitization. In a vertically disintegrated mortgage securitization market, prudent mortgage underwriting can be promoted or undermined by any entity that has the knowledge and power to influence originators' loan approval decisions. These entities may include originators themselves, securitizers such as GSEs and private banks that purchased individual loans from originators and packaged them for sale to investors, credit rating agencies, investors, or regulators. ${ }^{52}$

Underwriting shifted toward riskier loans in the years leading up to the financial crisis, especially from 2004 to $2007 .{ }^{53}$ As will be shown below, these were the years in which the securitization market became far less concentrated, origination became more concentrated, and buyer power of GSEs declined relative to supplier power of originators. ${ }^{54}$

50. Beck et al., supra note 45, at 223-24 (arguing that competition may not increase fragility); John H. Boyd \& Gianni De Nicoló, The Theory of Bank Risk Taking and Competition Revisited, 60 J. Fin. 1329, 1329-43 (2005); Ramon Caminal \& Carmen Matutes, Market Power and Banking Failures, 20 INT'L J. INDUS. ORG. 1341, 1341-61 (2002), available at http://www.iae.csic.es/investigatorsMaterial/a9167113500archivoPdf20526.pdf; Klaus Schaeck, Martin Cihak \& Simon Wolfe, Are Competitive Banking Systems More Stable?, 41 J. MONEY, CREDIT \& BANKING 711, 711-34 (2009) (finding that concentration and competition are both associated with greater financial system stability); Berger et al., supra note 45 , at 16 (arguing that information collected in twenty-three industrial nations supports a link between competition and fragility, but other dynamics may be at work).

51. See Beck et al., supra note 45, at 223-24 (finding that higher banking industry concentration relates to lower risk of financial crisis, but arguing that this relation may be mediated by some factor other than competition); Stijn Claessens \& Luc Laeven, What Drives Bank Competition?: Some International Evidence, 36 J. MONEY, CREDIT \& BANKING 563, 563-83 (2004); Schaeck et al., supra note 50, at 730.

52. See IMMERGLUCK, supra note 4, at 99-112.

53. ERic S. Belsky \& Nela Richardson, Understanding the BoOm and Bust in NONPRIME MORTGAGE LENDING 5-8 (2010), available at http://www.jchs.harvard.edu/sites/jchs.harvard.edu/files/ubb10-1.pdf; PRESIDENT's WORKING Grp. on Fin. Mkts., Policy Statement on Financial Market Developments 1 (2008) ("The turmoil in financial markets clearly was triggered by a dramatic weakening of underwriting standards for U.S. subprime mortgages, beginning in late 2004 and extending into early 2007.”) (emphasis omitted); Yuliya Demyanyk \& Otto Van Hemert, Understanding the Subprime Mortgage Crisis, 24 ReV. Fin. STUD. 1848, 1875-76 (2011).

54. See European Cent. Bank, Housing Finance in the Euro Area 74 (2009) ("Interestingly, the lending boom in the United States has coincided with the imposition of limits on the activity of GSEs, which triggered increased competition from new entrants."). 
Scholars, government commissions, and others have identified many possible causes of the financial crisis of the late 2000s. ${ }^{55}$ This Article focuses primarily on competitive dynamics and also discusses a limited subset of other possible contributing causes. The focused analysis in this Article is not meant to deny the importance of other contributing causes but rather to highlight factors that have not been adequately discussed in the literature and whose implications have been overlooked by leading proposals for market reform.

\section{A. Mortgage Underwriting Deteriorated from 2004 to 2007}

Both ex ante information about changes in loan characteristics over time and ex post loan performance suggest that loan quality was relatively stable or improving from 2000 to 2003 and then deteriorated sharply from 2004 to 2007.

Evidence of deteriorating underwriting standards in 2004 to 2007 includes a dramatic shift away from relatively safe loan categories to relatively risky loan categories. The origination market product mix shifted from relatively safe mortgages - including conventional conforming mortgages typically sold to the GSEs, FHA and VA loans, and private Jumbo loans which were generally high quality but were above the GSEs maximum loan limits - toward riskier mortgages, including subprime loans, Alt-A (low-documentation) loans, and second lien home equity loans.

Figure 4 below shows this dramatic shift. The bottom three shades are relatively safe loans while the top three shades are relatively riskier loans.

55. See, e.g., John C. Coffee, Jr., Ratings Reform: The Good, the Bad, and the Ugly, 1 Harv. Bus. L. Rev. 231 (2011); Claire A. Hill, Why Did Rating Agencies Do Such a Bad Job Rating Subprime Securities?, 71 U. PITT. L. ReV. 585 (2010); Benjamin J. Keys, Tanmoy Mukherjee, Amit Seru \& Vikrant Vig, Did Securitization Lead to Lax Screening? Evidence from Subprime Loans, 125 Q.J. ECON. 307 (2010); Atif Mian \& Amir Sufi, The Consequences of Mortgage Credit Expansion: Evidence from the U.S. Mortgage Default Crisis, 124 Q.J. ECON. 1449 (2009); Steven L. Schwarcz, Protecting Financial Markets: Lessons from the Subprime Mortgage Meltdown, 93 MinN. L. REV. 373 (2008). These include, but are not limited to, conflicts of interest at credit rating agencies and overly optimistic credit ratings for MBS; ample liquidity, low interest rates, and investors reaching for higher yields; moral hazard and information inefficiencies related to securitization; conflicts of interest and information inefficiencies related to financial innovations such as collateralized debt obligations; limited liability, high leverage, and financial executives' incentivized to take big risks; fragmented and light-touch regulation; and possibly affordable housing policies. 
Figure 4: From 2004 to 2007, origination shifted dramatically away from safe prime mortgages toward risky, subprime and Alt-A mortgages and home equity loans

U.S. residential mortgage origination, by product, 1990-2010 Market share, percent

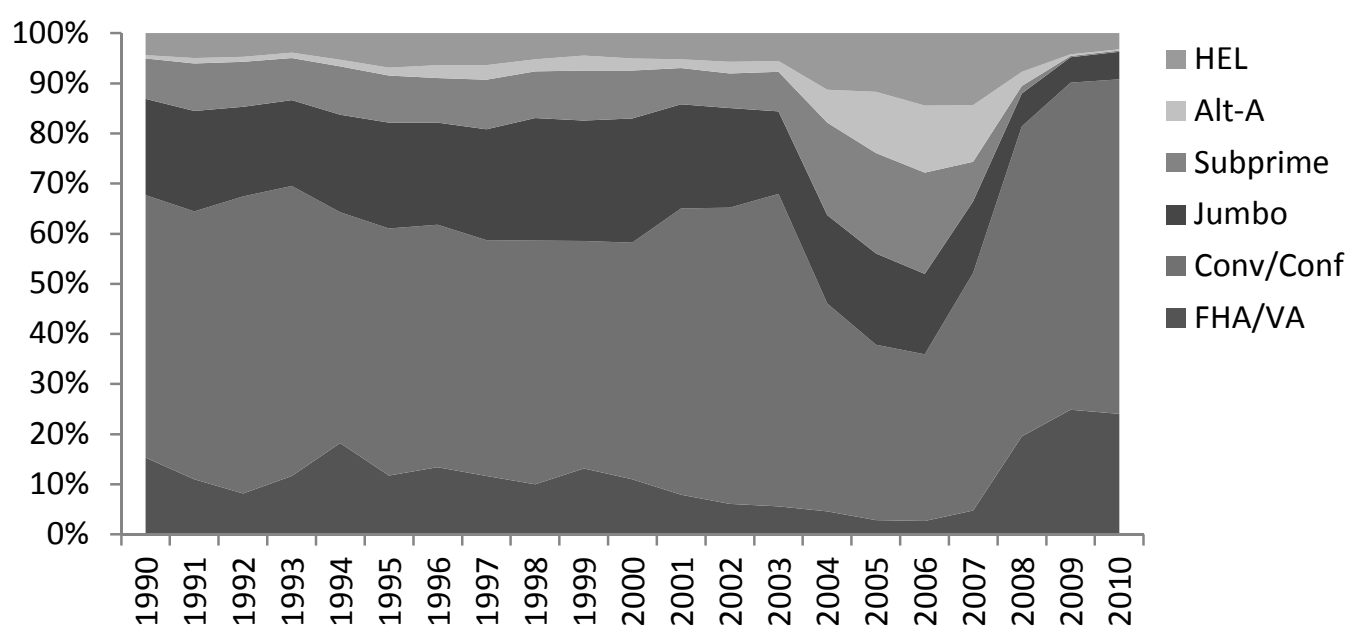

Source: 2011 Mortgage Market Statistical Annnual, Vol. 1, p. 20.

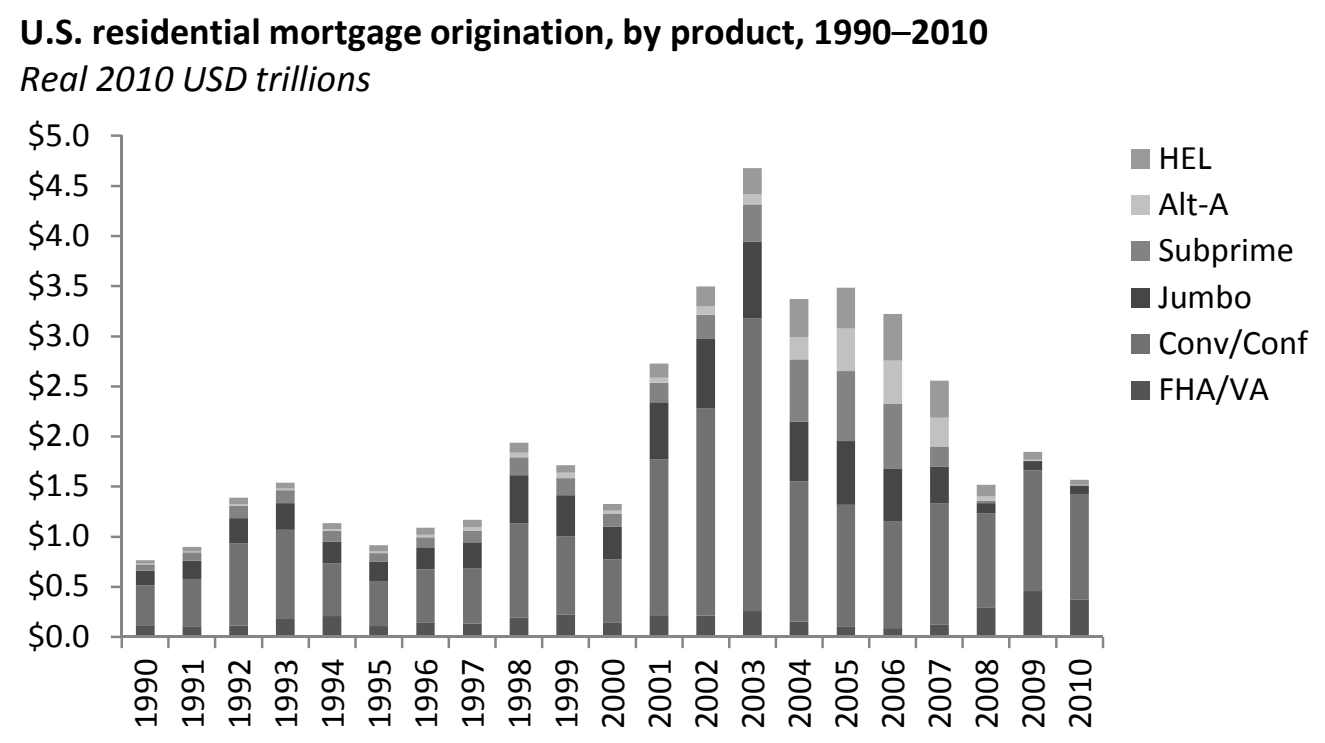

Source: 2011 Mortgage Market Statistical Annnual, Vol. 1, p. 20; Bureau of Labor Statistics. 
Conventional conforming mortgages experienced the most sudden and dramatic declines, losing almost half of their market share in two years. ${ }^{56}$ Subprime mortgages increased dramatically, from approximately $7-8 \%$ of the market in 2000 to 2003 , to approximately $18-20 \%$ in 2004 to $2006 .^{57}$

Deteriorating underwriting standards were also manifest in the proliferation of nontraditional mortgage loan features, such as adjustable rate mortgages (ARMs), ${ }^{58}$ interest only mortgages, pay option mortgages, and mortgages with large final payments known as balloon payments. ${ }^{59}$ The market share of loans with these features increased dramatically from 2004 to $2007 .{ }^{60}$ Simultaneous second mortgages (also called "piggyback" loans) proliferated, and combined-loan-tovalue ratios climbed. ${ }^{61}$ The percent of loans with full documentation fell from the first quarter of 2005, bottoming out in the subprime market in late 2006 and in the prime and Alt-A markets in early $2007 .^{62}$

Further evidence of deteriorating underwriting from 2004 to 2007 comes from assessments by national bank examiners that underwriting standards tightened from 2000 to 2003, then loosened from 2004 to 2007. Figure 5 below shows the net percent of national bank examiners who reported tightening residential mortgage

56. Conventional conforming mortgages increased their market share from 2000 to 2003 , increasing from $47 \%$ to $62 \%$, then plummeted from 2004 to 2006 , reaching a low of $33 \%$ in 2006, and began to recover thereafter. FHA and VA loans experienced steady declines, falling from $11 \%$ in 2000 to $3 \%$ in 2006. Private Jumbo loans experienced a gradual decline, peaking at $25 \%$ in 1999 and declining thereafter.

57. Alt-A loans also increased from $1-3 \%$ in 1990 to 2003 to $7-11 \%$ in 2004 , with a peak of $13 \%$ in 2006 . Home equity loans' market share doubled, from about $5-6 \%$ in 2003 to $11-14 \%$ in 2004 to 2007.

58. BELSKY \& RiCHARDSON, supra note 53, at 38, 159 (using First American CoreLogic, LoanPerformance data to show that subprime loans shifted from primarily fixed rate mortgages (FRMs) to ARMs). ARMs are far more likely to default than FRMs, as shown in Figure 12. ARMs are default prone because the required monthly payments can dramatically increase as short-term interest rates increase, whereas borrowers' capacity to pay (i.e, monthly income) typically does not increase as short-term interest rates increase. ARMs also often feature low initial teaser rates which reset to higher floating rates after a few years. See id. at 39, 160 fig.2-6. The choice between ARMs and FRMs is essentially a question of who should forecast and hedge interest rate risk-individual retail borrowers or sophisticated financial professionals working at large institutions.

59. Interest only, pay option, and balloon payment mortgages are risky because they amortize more slowly than traditional mortgages and therefore loan-to-value ratios remain higher for a longer period of time. Underwriting often relies on optimistic projections of rising borrower income, rising home prices, and ample opportunities to refinance. These mortgages may have low short-term default rates because required payments are initially low, but they will typically have either higher long-term default rates or higher loss rates in the event of default.

60. Belsky \& Richardson, supra note 53, at 159 fig.2-5; see also 1 InSIDE Mortg. Fin., The 2011 Mortgage Market Statistical ANNUAL 23 (2011).

61. Belsky \& Richardson, supra note 53, at 36; Ivy L. Zelman, DenNis McGill, Justin Speer \& Alan Ratner, Mortgage Liquidity du Jour: Underestimated No More 34 (2007) (Credit Suisse equity research), available at http://seattlebubble.com/blog/wpcontent/uploads/2007/10/2007-03-credit-suisse-mortgage-liquidity-du-jour.pdf.

62. BELSKY \& RichARDSON, supra note 53, at 39, 161 fig.2-7. 
underwriting standards in the Office of the Comptroller of the Currency's (OCC) annual survey of bank examiners.

Figure 5: Underwriting standards tightened from 2000 to 2003 , eased from 2004 to 2007, then tightened sharply after the mortgage crisis

\section{Changes in underwriting standards for residential real estate loans, 1996-2011 Net percentage of national banks tightening underwriting standards*}

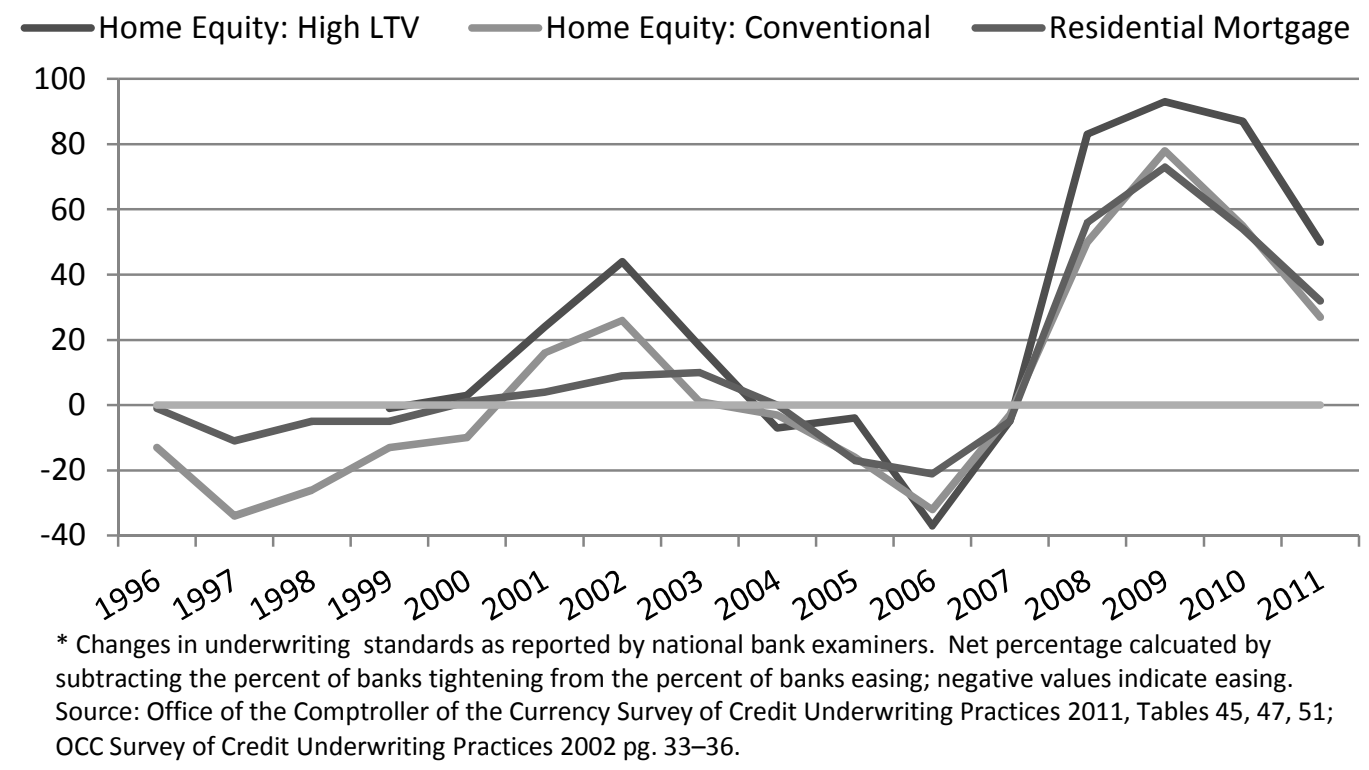

The OCC's annual survey reported that for both commercial and retail lending, banks that eased underwriting standards did so primarily because of competition. ${ }^{63}$

These changes in underlying loan quality are largely consistent with the subsequent pattern of loan performance. Figure 6 below shows the percent of loans that were more than sixty days delinquent, by months since origination. ${ }^{64}$ Each line

63. Office of the Comptroller of the Currency, Survey of Credit Underwriting Standards 4-5 (2005); Office of the Comptroller of the CurRency, Survey of Credit UnderWriting Standards 6 (2006); OfFice of THE COMPTROLler of THE CuRRENCY, SURVEY OF CREDIT UNDERWRITING STANDARDS 3, 5 (2007).

64. A similar analysis appeared in an October 2008 publication by the International Monetary Fund (IMF). InT'L Monetary Fund, Global Financial Stability Report: Financial Stress and Deleveraging: Macrofinancial Implications and Policy 12 fig.1.8 (2008). The IMF's analysis showed essentially the same pattern of improving performance from 2000 to 2003, followed by deteriorating performance from 2004 to 2007, but delinquencies were scaled by original loan balance instead of by current balance. Id. Two researchers at the IMF who prepared the original analysis, Narayan Suryakumar and Rebecca McCaughrin, graciously shared updated data and provided guidance. The advantage 
represents a different vintage year; the time scale on the $\mathrm{x}$-axis is relative to the date of origination. A more steeply upward sloping line for a given vintage year suggests a higher percentage of delinquent loans within a shorter period of time since origination, and therefore poorer performance.

Three charts are presented, one for subprime loans, one for Alt-A (lowdocumentation) loans, and one for prime loans.

Figure 6: Loan performance by vintage improved from 2000 to 2003 and then deteriorated from 2004 to 2007

\section{U.S. Subprime mortgage delinquencies by vintage year}

Percentage of current balance 60+ days delinquent, by months since origination

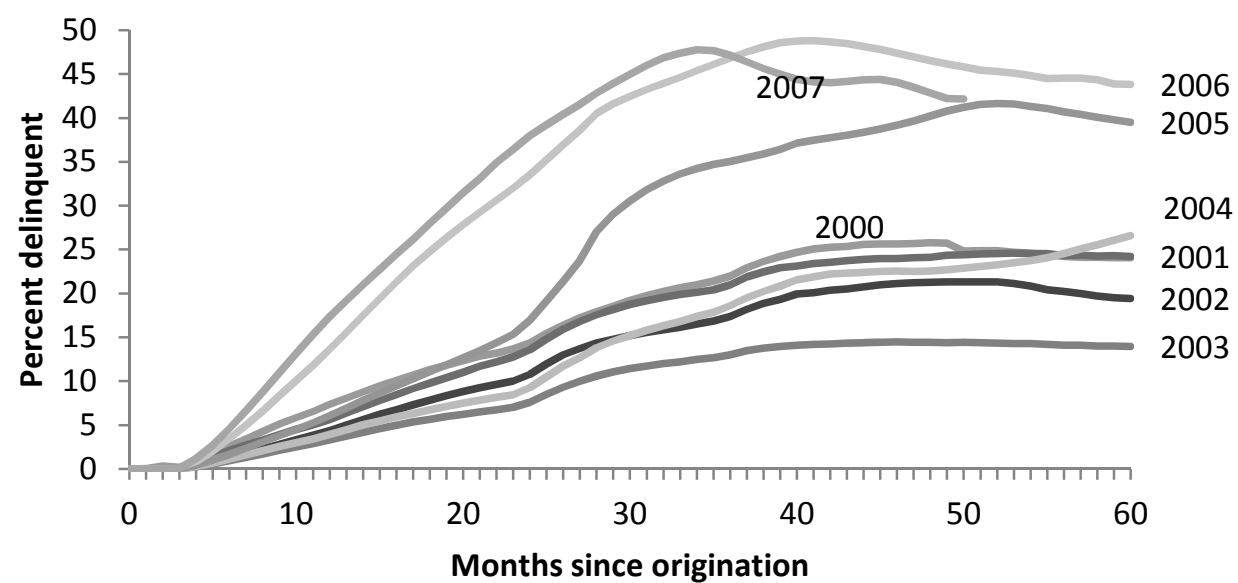

Note: Delinquencies include foreclosures and bank-owned real estate. Current loan balance is current as of April 2011.

Source: International Monetary Fund, Corelogic Loan Performance

of scaling the data by the current balance is that the resulting performance figures are less likely to be skewed by differences across vintages in refinancing and loan modification rates. Reported delinquency rates are generally higher than they would be if scaled by original loan balance. 


\section{U.S. Alt-A mortgage delinquencies by vintage year}

Percentage of current balance $60+$ days delinquent, by months since origination

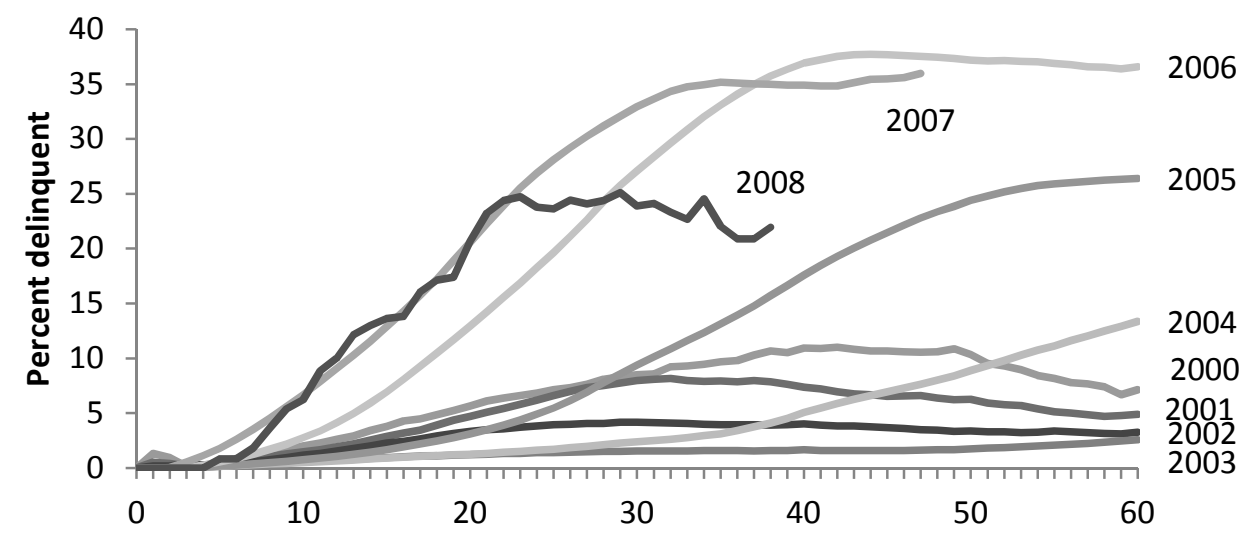

Months since origination

Note: Delinquencies include foreclosures and bank-owned real estate.

Current loan balance is current as of April 2011.

Source: International Monetary Fund, Corelogic Loan Performance database

\section{U.S. Prime mortgage delinquencies by vintage year}

Percentage of current balance $60+$ days delinquent, by months since origination

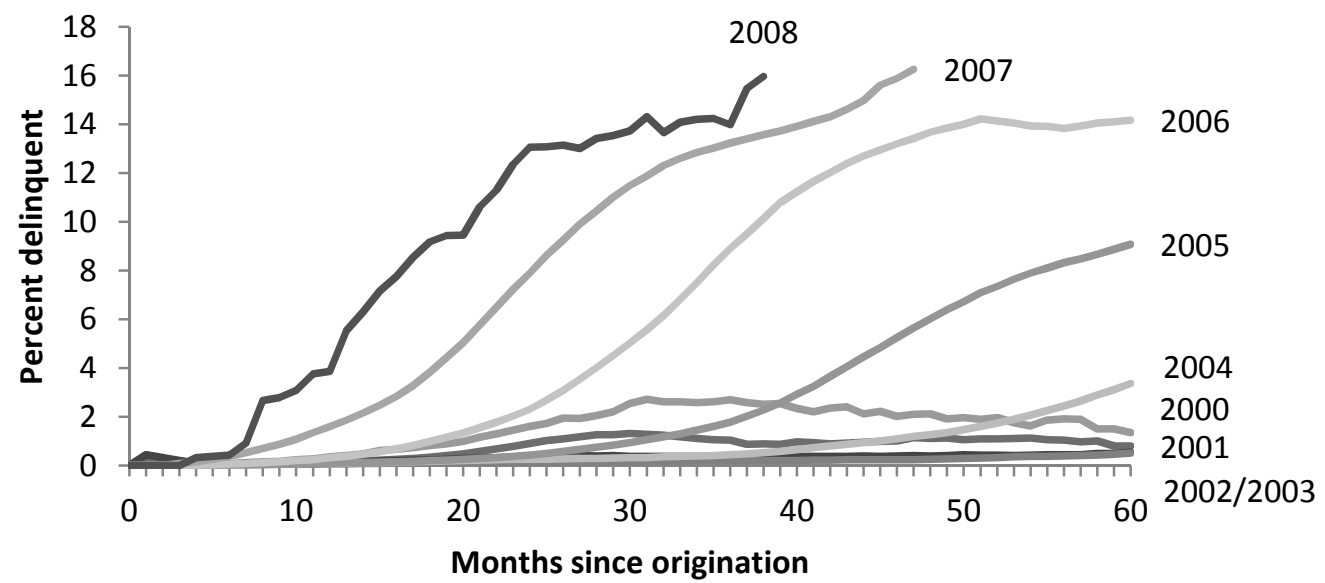

Note: Delinquencies include foreclosures and bank-owned real estate.

Current loan balance is current as of April 2011.

Source: International Monetary Fund, Corelogic Loan Performance database

Loan quality at origination may not fully explain the pattern of subsequent loan performance; economic shocks after origination such as changes in housing values, 
unemployment, and liquidity also play a role. ${ }^{65}$ The overall pattern of changes in unemployment should make 2000 to 2003 vintage loans perform worse relative to 2004 to 2006 vintage loans, and therefore bolsters support for the claim that underwriting loosened from 2004 to $2006 .{ }^{66}$

The impact of housing price changes is somewhat more challenging to interpret. The pattern of changes in housing prices could make later loans perform worse, even with consistent underwriting standards. ${ }^{67}$ However, declines in housing prices may have been foreseeable. In the early to mid-2000s, a number of scholars and regulators argued that housing was overpriced. ${ }^{68}$ They noted deviations from historic relationships between housing prices and rental prices, as well as between housing prices and economic fundamentals such as wages, employment, and population levels. Nevertheless, mortgage lenders continued to make loans that

65. The existing literature suggests that changes in unemployment levels and housing prices are particularly good predictors of default. See generally Karl E. Case, Robert J. Shiller \& Allan N. Weiss, Mortgage Default Risk and Real Estate Prices: The Use of IndexBased Futures and Options in Real Estate (Nat'l Bureau of Econ. Research, Working Paper No. 5078, 1995); Ronel Elul, Nicholas S. Souleles, Souphala Chomsisengphet, Dennis Glennon \& Robert Hunt, What "Triggers" Mortgage Default? (Research Dep't, Fed. Reserve Bank of Phila., Working Paper No. 10-13, 2010), available at http://ssrn.com/abstract=1596707.

66. National unemployment rates generally increased from around $4 \%$ in mid-2000 to around $6.3 \%$ in mid-2003 then generally decreased through mid-2007, when unemployment reached $4.6 \%$. Unemployment rates increased through year-end 2009 , then started to decrease. Unemployment reached $5 \%$ by the end of $2007,7.4 \%$ by the end of $2008,10 \%$ by the end of 2009 , and then declined to $9.4 \%$ by the end of 2010 . Timing varies somewhat by locality. See Civilian Unemployment Rate, FED. RESERVE BANK OF ST. LouIS, http://research.stlouisfed.org/fred2/data/UNRATE.txt.

67. See, e.g., Geetesh Bhardwaj \& Rajdeep Sengupta, Where's the Smoking Gun? A Study of Underwriting Standards for U.S. Subprime Mortgages 10-14 (Fed. Reserve Bank of St. Louis, Working Paper No. 2008-036E, 2011), available at http://ssrn.com/abstract=1286106 (arguing that within the category of subprime mortgages, underwriting actually strengthened from 2004 to 2006 based on FICO scores, and that high defaults in 2004 and later vintages may be due to declining housing prices). Nationwide housing prices generally appreciated through mid-2006, then declined. Press Release, S\&P Indices, Home Prices Continued to Decline in November 2011 According to the S\&P/Case-Shiller Home Price Indices (Jan. 31, 2012), available at http://www.standardandpoors.com/indices/sp-case-shiller-home-priceindices/en/us/?indexId=spusa-cashpidff--p-us. As with unemployment, timing varies somewhat by locality.

68. See Dean Baker, Ctr. for Econ. \& Policy Research, The Housing Bubble Fact SHEET (2005), available at http://www.cepr.net/documents/publications/housing_fact_2005_07.pdf; Dean Baker, The Run-up in Home Prices: A Bubble, Challenge, Nov.-Dec. 2002, at 93; Karl E. Case \& Robert J. Shiller, Is There a Bubble in the Housing Market?, BROOKINGS PAPERS ON ECON. ACTIVITY, Vol. 2: 2003, at 299, available at http://muse.jhu.edu/journals/eca/summary/v2003/2003.2case.html; Nouriel Roubini, Why Central Banks Should Burst Bubbles, 9 INT'L FIN. 87 (2006). Other experts argued there was no bubble. See Jonathan McCarthy \& Richard W. Peach, Are Home Prices the Next "Bubble"?, 10 ECON. POL'Y REV., Dec. 2004, at 1, 10, available at http://papers.ssrn.com/sol3/papers.cfm?abstract id=634265; Suzanne Stewart \& Ike Brannon, A Collapsing Housing Bubble?, REGUlATION, Spring 2006, at 15, 15-16, available at $\mathrm{http}: / /$ papers.ssrn.com/Sol3/papers.cfm?abstract_id=898196; Michael D. Bordo, U.S. Housing Price Boom-Busts in Historical Perspective 7 (Ind. State Univ. Networks Fin. Inst., Policy Brief 2005-PB-02, 2005), http://papers.ssrn.com/sol3/papers.cfm?abstract_id=923865. 
depended on optimistic projections of housing appreciation. ${ }^{69}$ The assumption of continued increases in housing prices in the face of a likely housing bubble was itself a relaxation of underwriting standards. ${ }^{70}$

All three data sources - ex ante loan characteristics, contemporaneous surveys of knowledgeable experts, and ex post loan performance - are consistent with a dramatic deterioration in loan quality at origination for 2004 to 2007 vintages.

This data raises an intriguing question: why did loan quality deteriorate so dramatically during these years? Many of the possible contributing causes that have been identified in the literature existed long before 2004 to 2007. Was some sort of tipping point suddenly reached?

A casual glance at Figure 2 suggests that dramatic changes took place in the market during these years, as private securitizers gained market share while the GSEs and government agencies lost ground. Could this reversal in securitizer market share have led to changes in underwriting by originators?

\section{B. GSEs Historically Monitored and Disciplined Originators}

The GSEs historically controlled originators by establishing national standards for "conforming" loans as well as standardized documents, underwriting practices, loan products, and servicing arrangements. ${ }^{71}$ Centralization not only enhanced GSE control; it also increased efficiency and contributed to MBS market growth and liquidity. ${ }^{72}$ Notable efficiency gains included the use of automated underwriting based on objective, statistically validated criteria for predicting default risk. ${ }^{73}$

69. See Geetesh Bhardwaj \& Rajdeep Sengupta, Subprime Mortgage Design 3 (Fed. Reserve Bank of St. Louis, Working Paper No. 2008-039E, 2010), available at http://ssrn.com/abstract=1290716 (demonstrating that subprime contracts depended on prepayments and that the subprime boom was sustained by high and early prepayments during a period of house price appreciation); Gary Gorton, The Panic of 200767 (Int'l Ctr. for Fin. at Yale Sch. of Mgmt. \& Nat'l Bureau of Econ. Research, Working Paper No. 08-24, 2008), available at http://ssrn.com/abstract $=1255362$ (demonstrating that the design of subprime mortgage contracts depended on continued housing price appreciation).

70. See Bhardwaj \& Sengupta, supra note 69, at 15-16 (acknowledging that the growth of the subprime market itself constitutes deterioration of underwriting standards in the overall U.S. mortgage market); Mian \& Sufi, supra note 55, at 1467-71 (showing zip-code level increases in neighborhood debt-to-income ratios).

71. BELSKY \& RICHARDSON, supra note 53, at 14, 17-19.

72. BELSKY \& RichARDSON, supra note 53, at 14; Richard K. Green \& Ann B. Schnare, The Rise and Fall of Fannie Mae and Freddie Mac: Lessons Learned and Options for Reform (Empiris, LLC, 2009), available at http://ssrn.com/abstract=1509722; INGRID GOULD ELLEN, John NAPIER TyE \& MARK A. WiLlis, NYU FuRMAN CTR. FOR REAL ESTATE \& URBAN Policy, Improving U.S. Housing Finance through Reform of FANNiE MaE and Freddie MaC: ASSESSING THE OPTIONS 4-7 (2010), http://furmancenter.org/files/publications/Improving_US Housing_Finance_Fannie_Mae_Freddie_Mac_9_8_10.pdf.

73. Automated underwriting replaced an expensive, subjective process with one that was faster, cheaper, and did not appear (at least initially) to produce results that were any worse. BELSKY \& RiCHARDSON, supra note 53, at 17-19; BD. OF GOVERNORS OF THE FED. Reserve Sys., Report to the Congress on Credit Scoring and Its EfFects on the AvAilABILITY AND AfFORDABILITY OF CREDIT S-2 (2007), available at http://www.federalreserve.gov/boarddocs/rptcongress/creditscore/creditscore.pdf. See also Ryan Bubb \& Alex Kaufman, Securitization and Moral Hazard: Evidence from a Lender 
The GSEs also exercised control through contractually negotiated rights to sell back to originators loans that did not comply with GSE standards, that breached representations and warranties, and that subsequently became nonperforming. ${ }^{74}$ Compared to private securitizers, the GSEs have been more aggressive in their use of such repurchase agreements, ${ }^{75}$ and more successful in enforcing their rights against originators. ${ }^{76}$ By bringing claims based on these repurchase agreements, the GSEs have already recovered from originators between $10 \%$ and $15 \%$ of their credit losses. $^{77}$

The GSEs' large market share and therefore large buyer power may have helped them maintain tighter control over originators compared to other securitizers. ${ }^{78}$

Cutoff Rule 13-14 (Fed. Reserve Bank of Bos., Paper No. 09-5, 2009), available at http://www.bos.frb.org/economic/ppdp/2009/ppdp0905.pdf; Hollis Fishelson-Holstine, The Role of Credit Scoring in Increasing Homeownership for Underserved Populations 4, 16 (Harvard Joint Ctr. for Hous. Stud., Working Paper No. BABC 04-12, 2004), available at http://www.jchs.harvard.edu/sites/jchs.harvard.edu/files/babc_04-12.pdf. See generally Susan Wharton Gates, Vanessa Gail Perry \& Peter M. Zorn, Automated Underwriting in Mortgage Lending: Good News for the Underserved?, 13 Housing Pol'y Debate 369 (2002).

74. When mortgage insurers rescind coverage, or a loan defaults, GSEs require indemnification against potential losses or that the loan be repurchased. Fannie Mae, Annual Report (Form 10-K) 167-172 (Feb. 26, 2010); see also JPMorgan Chase \& Co., Annual Report (Form 10-K) 98 (Feb. 28, 2011); Fin. Crisis InQuiry COMM'N, The Financial CRISIS INQUIRY REPORT 224 (2011) [hereinafter FCIC REPORT].

75. One of the largest originators, JP Morgan Chase \& Co., reports that its repurchase agreements liability is 'predominantly' with the GSEs and that repurchase demands from "private-label securitizations have been limited." JPMorgan Chase \& Co., Annual Report (Form 10-K) 98, 122 (Feb. 28, 2011). Similarly, Bank of America (which has acquired Countrywide, one of the largest originators), reports that non-GSE repurchase agreements have "less rigorous representations and warranties" and therefore present less risk to originators. BANK OF AM. CORP., 2010 ANNUAL REPORT 59 (2011). Bank of America notes that GSEs can force repurchases of individual loans when those loans default and an investigation reveals that the loans did not meet GSE standards, whereas private securitization investors can generally only trigger a repurchase if misrepresentations are so severe that it "materially and adversely affects the interest of all investors." Id. at 59, 187.

76. Bank of America's 2010 annual report reveals that the GSEs have brought more claims, both in absolute terms and as a percentage of loans purchased, than private securitization investors, and the GSEs have been more successful in resolving those claims. See BANK OF AM. CORP., supra note 75, at 57-59. On \$1.1 trillion in loan sales to the GSEs from 2004 to 2008, the GSEs brought $\$ 21.6$ billion in claims, or approximately 2\%. Of these claims, $\$ 18.2$ billion, or over $80 \%$, have been resolved, with Bank of America claiming net losses of 27\%. On 963 billion in loan sales to private securitizations, investors and private mortgage insurers brought $\$ 13.7$ billion in claims, or less than $1.5 \%$. Of these claims, $\$ 6$ billion, or less than half, have been resolved. Recent news reports suggest that Bank of America may be settling more claims with private investors. See Dan Fitzpatrick, BofA Nears Huge Settlement, WSJ.com (June 29, 2011), http://online.wsj.com/article/SB10001424052702304447804576414222265248768.html.

77. FCIC REPORT, supra note 74, at 224 ("[D]uring the three years and eight months ending August 31, 2010, Freddie and Fannie required sellers to repurchase 167,000 loans totaling \$34.8 billion. So far, Freddie has received \$9.1 billion from sellers, and Fannie has received $\$ 11.8$ billion-a total of $\$ 20.9$ billion. The amount put back is notable in that it represents $21 \%$ of $\$ 163$ billion in credit-related expenses recorded by the GSEs since the beginning of 2008 through September 2010.”) The GSEs' actual recovery of \$20.9 billion is $13 \%$ of $\$ 163$ billion.

78. See, e.g., Ryan Bubb \& Alex Kaufman, Securitization and Moral Hazard: Evidence from 
Enforcing repurchase agreements requires sampling loans to identify those that are defective. In the mid-2000s, private securitizers in need of loans from originators reduced their loan sampling rates ${ }^{79}$ and waived in many noncompliant loans. ${ }^{80}$ Originators also often "gamed" securitizers' quality control systems, resubmitting previously rejected loans in new pools. ${ }^{81}$ Resubmissions would presumably be less likely to succeed if the securitization market was highly concentrated and a single securitizer was reviewing the same loan a second time.

The GSEs' most powerful tool for exercising control over originators may have been their centralized purchasing power. The GSEs can discipline originators by ending their relationship if the originator fails to comply with GSE underwriting standards or if there is an unusual increase in defaults of the originator's loans. ${ }^{82} \mathrm{~A}$ decision by the GSEs to cut off funding for an originator by refusing to purchase that originator's loans could have a devastating and almost immediate impact on the originator's revenues and potential profits. The GSEs have in fact cut off a number of originators over the years, usually putting those originators out of business. ${ }^{83}$ Since the financial crisis caused private securitizers to exit the market and thereby enhanced GSE buyer power, the GSEs have become more aggressive with originators. ${ }^{84}$

Standard setting by the GSEs is most influential if there are no alternatives. To the extent that non-GSE securitizers created alternative, competing channels for originators to sell their loans, they undermined the GSEs' ability to control originators ${ }^{85}$ In a competitive market for loans, any securitizer who attempted to

Credit Score Cutoff Rules, RES. REV., July-Dec. 2011, at 9 ("The ubiquity of . . credit score cutoff rules in the mortgage markets is a testament to the ability of Fannie and Freddie to enforce their underwriting guidelines through software programs, contractual provisions, and monitoring. . . . [L]arge securitizers like Fannie and Freddie were to some extent able to regulate lenders' screening behavior."), available at http://www.bos.frb.org/economic/ResearchReview/issue16/issue16.pdf.

79. See FCIC REPORT, supra note 74, at 165.

80. See id. at 166 .

81. Id. at 168 .

82. Bubb \& Kaufman, supra note 78, at 22; see also FANNIE MAE, SELling Guide: FAmily MAE SingLE FAMILY A2-3 (2011), available at https:/www.efanniemae.com/sf/guides/ssg/sg/pdf/sel072611.pdf; FREDDIE MAC, SinGLE-FAMILY SELLER/SERVICER GuIDE 5.2 (2012), available at http://www.freddiemac.com/sell/guide/.

83. Bubb \& Kaufman, supra note 73 , at 22. Fannie Mae terminated New Century Financial Corporation in March of 2007, effectively putting them out of business. Jonathan Stempel, New Century Cut Off by Fannie Mae, Shut in Calif., ReuTERS.COM (Mar. 20, 2007), http://www.reuters.com/assets/print?aid=USN2037637320070320. Freddie Mac and Ginnie Mae suspended Taylor, Bean \& Whitaker Mortgage Corporation in August of 2009, effectively putting them out of business. Adam Quinones, Taylor, Bean \& Whitaker Shuts Down Lending Operations, MorTg. News DAily (Aug. 5, 2009, 1:47PM), http://www.mortgagenewsdaily.com/08052009_tbw_shuts_down.asp.

84. Freddie Mac has begun to require larger sellers and servicers to agree to repurchase plans as well as financial penalties in the event of noncompliance with those plans. See Fed. Home Loan Mortg. Corp., Quarterly Report (Form 10-Q) 45 (May 4, 2011).

85. Originators were able to survive GSE termination when they could find an alternate source of funding. Although Fannie Mae terminated its relationship with First Beneficial Mortgage Corporiation in the late 1990s after discovering fraud, First Beneficial was able to continue obtaining funding from Ginnie Mae for several years because Fannie Mae did not share its discovery with other secondary market players. Kenneth M. Donohue, Fraud, Mortgage-Backed Securities and Ginnie Mae, Mortgage BAnking, June 2008, at 80. 
discipline originators would likely suffer a loss of market share to more lenient competitors. ${ }^{86}$ And compared to the GSEs, private securitizers were less capable of disciplining originators because each individual private securitizer was much smaller than the GSEs and therefore had less influence over large originators.

\section{Originators Consolidated and Diversified Away from Prime Mortgages}

Two developments in the origination market may have shifted the balance of power away from GSEs and toward originators. First, increasing concentration in the origination market may have enabled originators to counter GSE buyer power. Second, the growth of nonprime securitization gave originators an alternate option for funding and reduced their dependence on the GSEs.

Although specific local markets experienced an increase in the number of originators in the $2000 \mathrm{~s}$, much of the local growth came from the entry of large national chains into local markets. At the national level, a few large originators accounted for an increasing share of originations. Thus, there was both increased competition between originators at the local level, where lenders competed for individual borrowers, and reduced competition between originators at the national level, where large national originators sold mortgages in bulk to securitizers. Figure 7 below shows that mortgage origination has steadily become more concentrated at the national level. By 2004, the top ten players accounted for over $50 \%$ of originations, and climbing.

86. IMMERGLUCK, supra note 4, at 103, 111. 
Figure 7: Mortgage origination became highly concentrated

\section{Market share of top mortgage originators, 1998-2010}

Percent of 1-4 family U.S. residential mortgages originated, by dollar volume

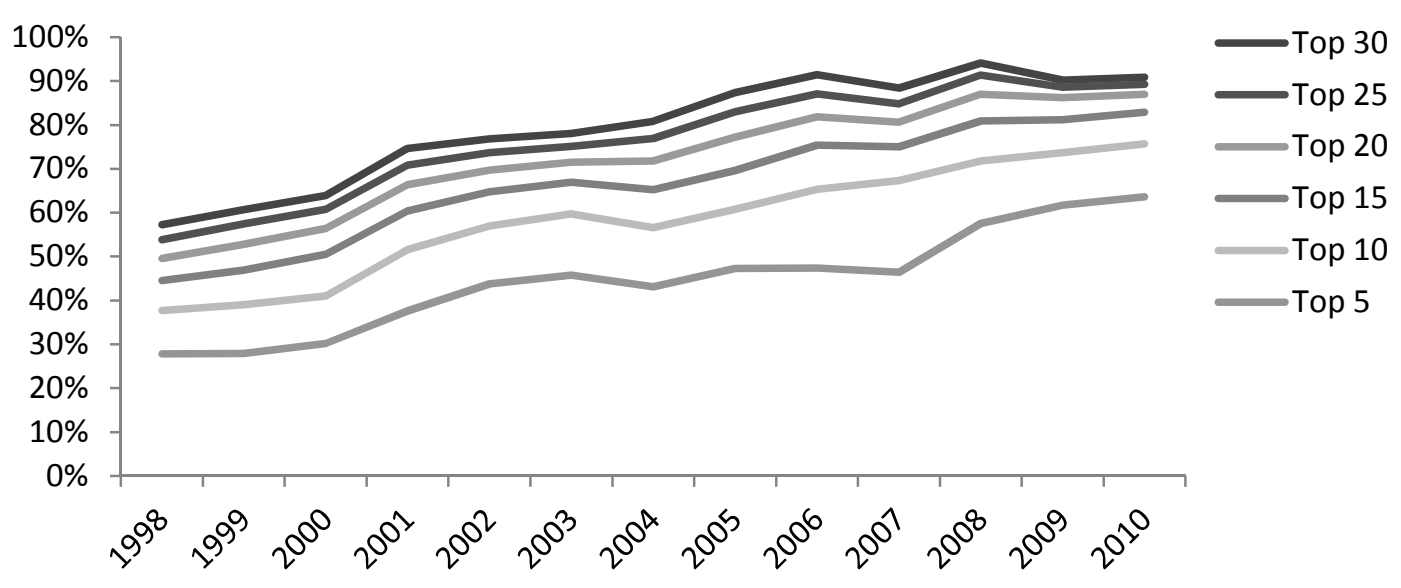

Source: Inside Mortgage Finance, 2011 Mortgage Market Statistical Annual Vol. 1, pg. 59-77.

Market share of top ten mortgage originators by loan type, 2000-2007

Percent of 1-4 family U.S. residential mortgages originated, by dollar volume

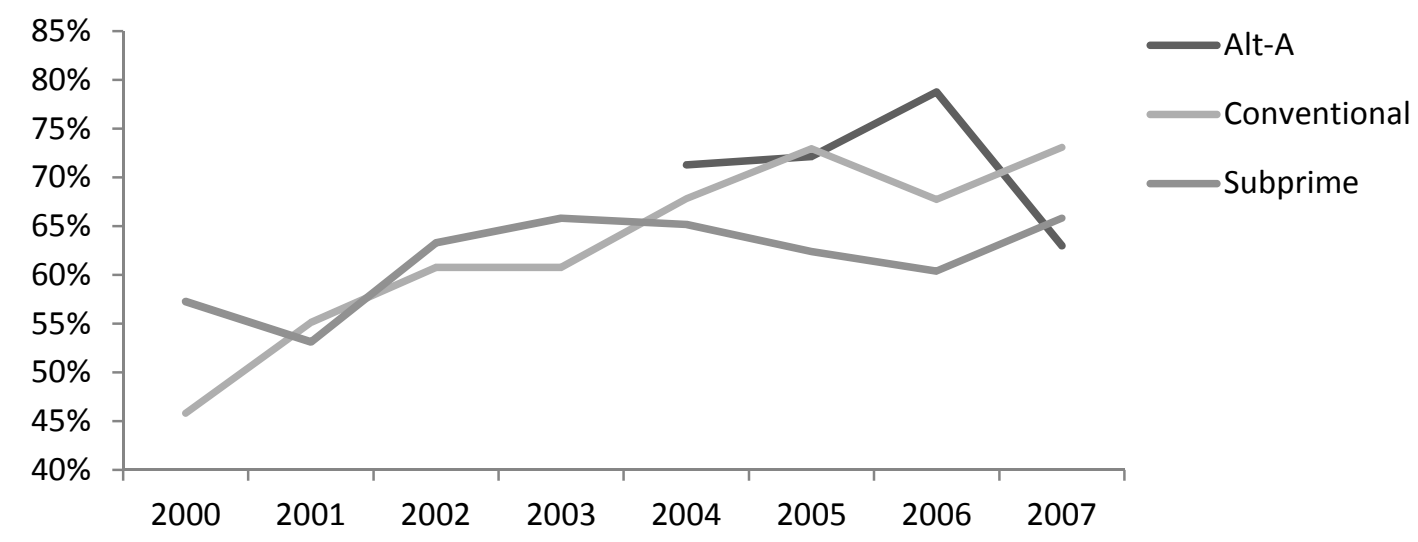

Source: Inside Mortgage Finance, 2011 Mortgage Market Statistical Annual Vol. 1, pg. 59-77, 106-16, 143$57,159-63$. 
Originators also diversified away from conventional/prime origination and toward nonprime origination. Nonprime lending did not simply grow because of growth at specialty nonprime originators; it grew in part because large, established prime originators entered the business of nonprime lending. ${ }^{87}$ As the top conventional/conforming mortgage originators diversified into nonprime mortgage originations, they became less dependent on the GSEs.

\section{Securitizers Competed for Market Share by Relaxing Standards}

Private bank securitizers' willingness to relax their underwriting standards and securitize nonprime loans enabled them to dramatically increase market share and race ahead of the GSEs. ${ }^{88}$ Nonprime mortgages were funded primarily through the private (non-GSE) securitization market. ${ }^{89}$ Because nonprime mortgages were securitized at a very high rate, as shown in Figure 8, and were primarily securitized by private banks, nonprime mortgages constituted a disproportionately large share of private label MBS issuance, as shown in Figure 9.

87. Whereas nonprime mortgage origination had once been a niche specialty, large, mainstream mortgage originators increasingly shifted toward nonprime origination. In 1998, the top six subprime lenders were Household Financial Services, Associates First Capital, ContiMortgage Corporation, IMC Mortgage Company, The Money Store, and Green Tree Financial. 1 InSIDE MoRTg. FIn., supra note 60 , at 157 . By 2007, the top six subprime mortgage originators included divisions of Citi, HSBC, Countrywide, Wells Fargo, Merrill Lynch, and Chase. See id. at 144.

88. See supra Figure 2 (showing a dramatic decline in GSE and FHA market share in 2004 to 2007).

89. 2 InSIDE MORTG. Fin., supra note 60 , at 3-6, 36. As discussed below, the GSEs purchased a significant quantity of the highest rated tranches of subprime and Alt-A private label MBS as portfolio investments. See infra note 197. As purchasers of select tranches of prepackaged MBS, the GSEs would likely have had far less control over individual loan selection than as purchasers and securitizers of individual whole loans. GSE MBS purchases, though substantial, were a minority of private label issuances. 
Figure 8: By 2004 to 2007, nonprime mortgages were securitized at the same rate as conventional conforming mortgages
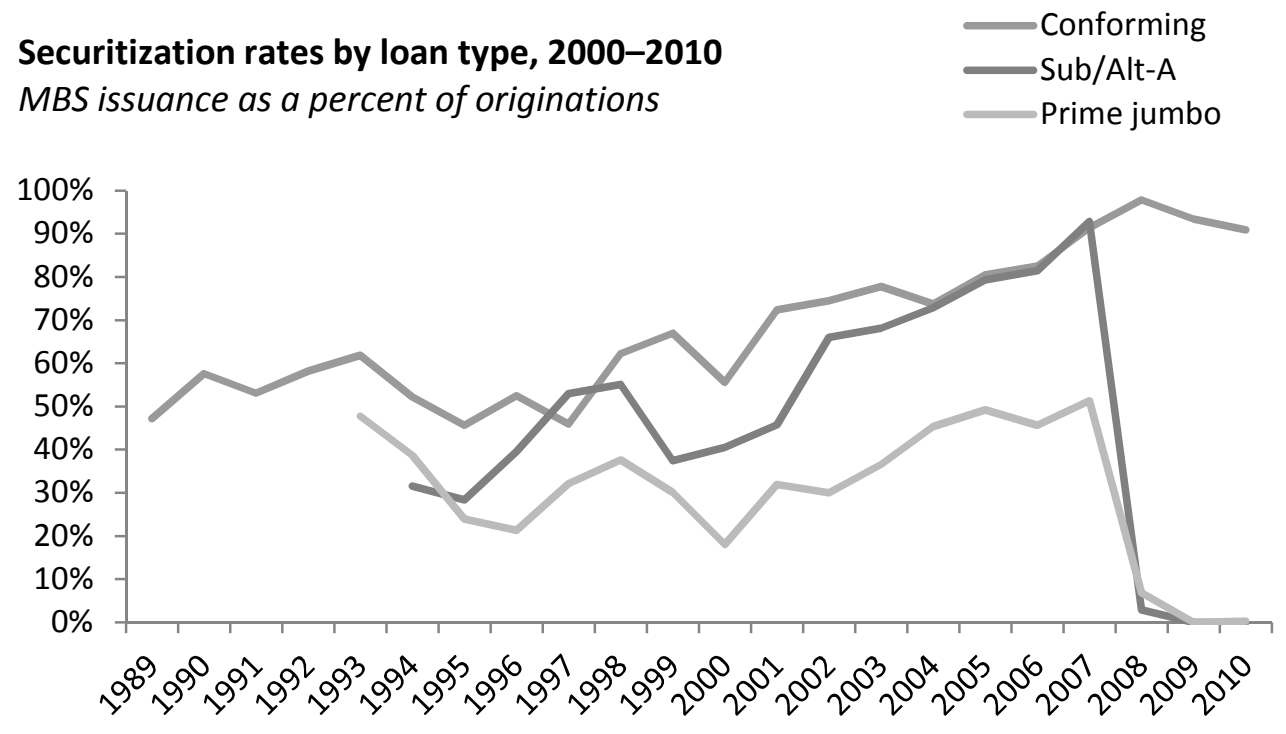

Source: Inside Mortgage Finance, 2011 Mortgage Market Statistical Annual Vol. 2, pg. 3-6.

Figure 9: Subprime and Alt-A loans accounted for most private label (nonGSE) MBS issuance and volume growth from 2004 to 2007

Non-Agency MBS issuance by type, 1995-2010

Real 2010 USD billions

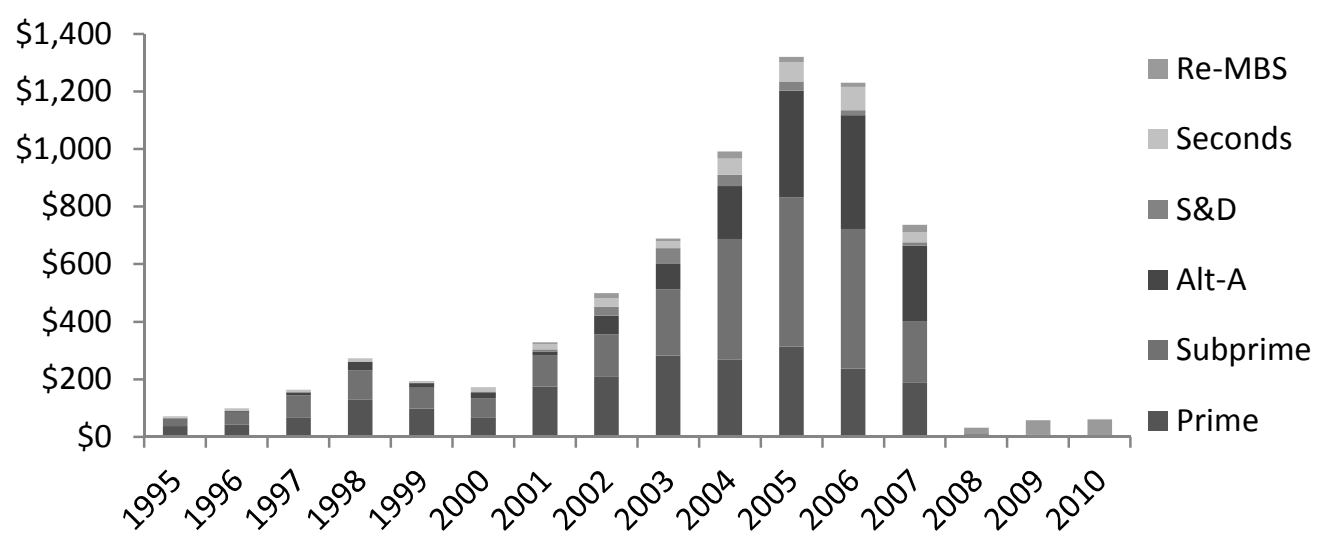

Note: Scratch-and-dent (S\&D) includes reperforming FHA/VA loans, resecuritized loans from exisiting MBS and conduit fallout loans. S\&D and second lien transactions backed by subprime loans are not included in the subprime category.

Source: Inside Mortgage Finance, 2011 Mortgage Market Statistical Annual, Vol. 2, pg. 31; Bureau of Labor Statistics. 


\section{E. Power Shifted from GSEs to Originators}

Figure 10 below shows an index of the relative buyer power of the GSEs and supplier power of the top conventional/conforming mortgage originators. Top conventional/conforming mortgage originators are defined as institutions that originated more than $\$ 400$ billion in conventional/conforming mortgages from 2000 to 2010 .

The fundamental assumption behind the index is that an originator who originates primarily conventional mortgages is more dependent on the GSEs to securitize and guarantee those mortgages than is an originator who has diversified and also originates subprime and Alt-A mortgages. Similarly, the index assumes that the GSEs are more dependent on conventional originators with larger market share because those originators are important suppliers of raw material. ${ }^{90}$

These assumptions are consistent with widely used business strategy frameworks such as Porter's Five Forces, which are based on the StructureConduct-Performance (SCP) paradigm in industrial organization economics. Porter posits that greater concentration and an absence of substitutes at one position in a production value chain confer greater market power on firms in that position, while greater concentration and market power of those firms' suppliers reduces those firms' bargaining power. ${ }^{91}$

As can be seen from Figure 10, the GSEs' power over the top conventional originators declined to relatively low levels in 2004 to 2007 , the years in which the worst quality mortgages were originated. ${ }^{92}$

90. See Patricia A. McCoy, Andrey D. Pavlov \& Susan M. Wachter, Systemic Risk Through Securitization: The Result of Deregulation and Regulatory Failure, 41 ConN. L. REV. 1327, 1366-71 (2009).

91. See Michael E. Porter, The Five Competitive Forces that Shape Strategy, Harv. Bus. Rev., Jan. 2008, at 78-93; see also Joe S. Bain, Industrial Organization (2d ed. 1968); Hans Degryse \& Steven Ongena, Competition and Regulation in the Banking Sector: A Review of the Empirical Evidence on the Sources of Bank Rents, in HANDBOOK OF FinANCIAL INTERMEDIATION AND BANKING 483 (Anjan V. Thakor \& W. A. Boot eds., 2007) (discussing the origins and developments in the SCP approach); Allen N. Berger, Asli Demirgüç-Kunt, Ross Levine \& Joseph G. Haubrich, Bank Concentration and Competition: An Evolution in the Making, 36 J. MONEY CREDIT \& BANKING 433 (2003), available at 2004 WLNR 22247923 (discussing developments in the SCP approach and alternative analyses).

92. For each originator, the index is the originator's dependence on the GSEsmeasured by the originator's annual conventional mortgage originations as a share of the originator's annual overall mortgage originations - divided by the GSEs' dependence on the mortgage originator-measured by the originator's annual conventional mortgage originations as a share of all annual conventional mortgage originations by all originators. 
[Vol. 88:213

Figure 10: The GSEs' buyer power relative to large originators' supplier power reached very low levels in 2004 to 2008

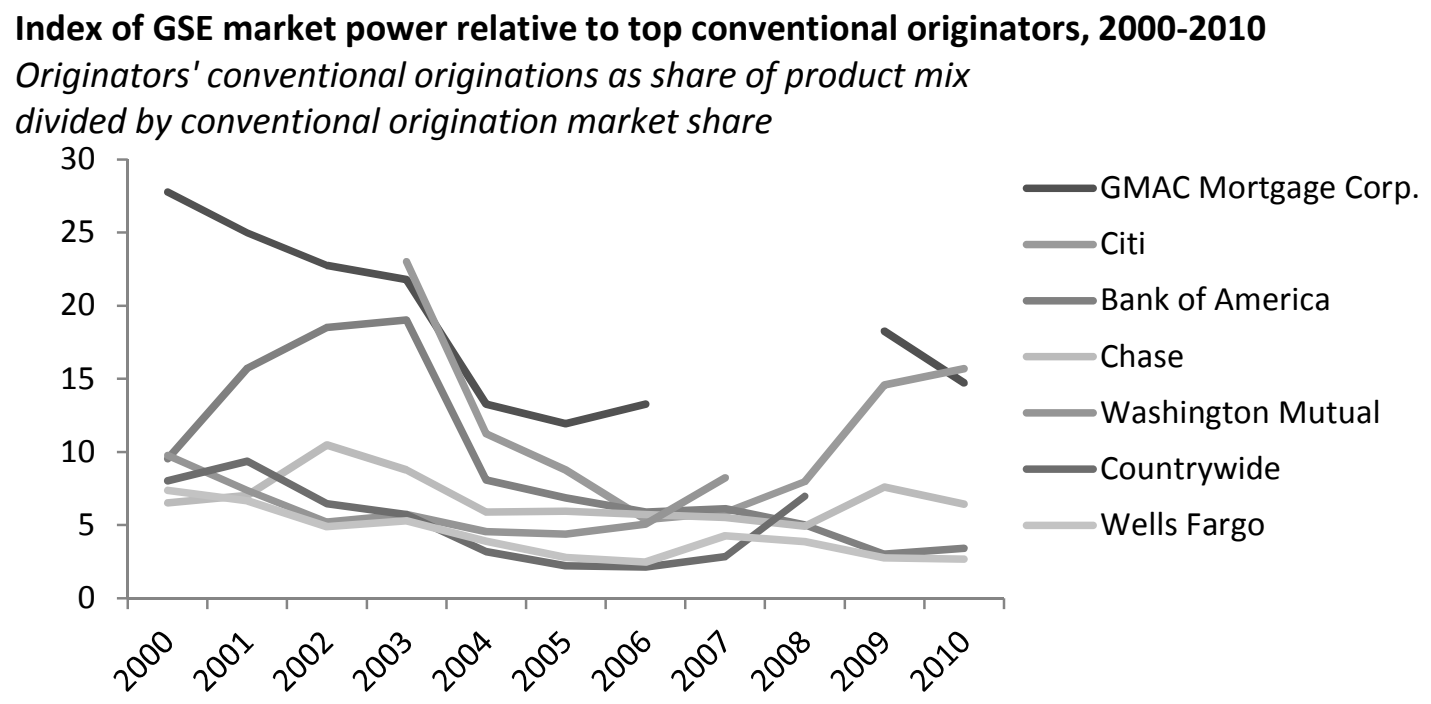

Source: Inside Mortgage Finance, 2011 Mortgage Market Statistical Annual Vol. 1, pg. 59-77, 106-16.

A new private market leader did not emerge to replace the GSEs and discipline originators. Although the private banks collectively captured more market share than the GSEs, no individual institution matched the GSEs' previous level of market dominance. ${ }^{93}$ In other words, as the GSEs lost market share, the secondary market became fragmented. Competitive, fragmented securitizers faced increasingly consolidated originators, ${ }^{94}$ and power shifted from securitizers to originators. Without a clear securitization market leader capable of enforcing standards and penalizing noncompliant originators, discipline broke down. ${ }^{95}$

One of the most impressive studies linking local level competition between originators to deteriorating mortgage underwriting standards in the years leading up to the mortgage crisis was conducted by three economists at the International Monetary Fund (IMF), Giovanni Dell'Ariccia, Deniz Igan, and Luc Laeven. ${ }^{96}$

93. See 2 Inside Mortg. Fin., supra note 60, at 9, 35-50.

94. See supra Figure 7 (showing increasing consolidation among mortgage originators).

95. See, e.g., Edward J. Janger \& Susan Block-Lieb, Consumer Credit and Competition: The Puzzle of Competitive Credit Markets, 6 Eur. CoMPETITION J. 68 (2010) (arguing that competition in the securitization market for loans diminished the standardizing force of Fannie Mae and Freddie Mac). See generally Erik F. Gerding, Deregulation Pas de Deux: Dual Regulatory Classes of Financial Institutions and the Path to Financial Crisis in Sweden and the United States (Univ. of N.M. Sch. of Law Legal Studies, Paper No. 2010-04, 2010), available at http://ssrn.com/abstract=1548753 (linking competition from the private sector to a loosening of underwriting standards).

96. See generally Giovanni Dell'Ariccia, Deniz Igan \& Luc Laeven, Credit Booms and Lending Standards: Evidence from the Subprime Mortgage Market (Eur. Banking Ctr., Working Paper No. 2009-14S, 2009), available at http://ssrn.com/abstract=1100138. 
Using data from 2000 to 2006 including over 50 million individual mortgage applications across 387 Metropolitan Statistical Areas, ${ }^{97}$ and controlling for local and national economic variables, ${ }^{98}$ the authors found that incumbents' lending standards ${ }^{99}$ declined after new competitors entered local markets. ${ }^{100}$ The authors argue that local lenders felt compelled to cut their underwriting standards to compete effectively with the new entrants. ${ }^{101}$

The authors' findings are consistent with the hypothesis that underwriting standards tend to be lower in fragmented markets where competition is more intense than in concentrated markets where competition is generally more restrained. Specifically, the authors found that subprime underwriting standards declined more in areas with a larger number of lenders and more new entrants. ${ }^{102}$

The authors also found substantial differences between the drivers of lending standards in prime and subprime mortgage markets: the effect of competition in driving down underwriting standards was largely limited to subprime mortgage markets. ${ }^{103}$ Whereas subprime lenders became less cautious as the number of applications increased, prime lenders became more cautious. ${ }^{104}$

One possible explanation for differences in the prime and subprime markets is that the GSEs - who remained major loan purchasers in the prime market but played a minor role in the subprime market ${ }^{105}$ - helped maintain higher

97. See id. at 1,9 .

98. Id. at 1 . The authors controlled for variables that might affect mortgage application denials, including average income, income growth, the unemployment rate, the selfemployment rate, and house price appreciation to take into account the role of collateral. Id. at 9-10. They also controlled for securitization rates. Id. at 5 .

99. The authors used two measures of lending standards: denials as a percent of loan applications and loan-to-income ratios. Id. at 1, 9 .

100. Id. at 2,21 .

101. Id. at 2 .

102. Id. at 2 ("Denial rates declined more in areas with a larger number of competitors."); $i d$. at 18 ("A one standard deviation increase in the number of competitors reduces MSAlevel subprime denial rates by 3 percentage points . . ."); $i d$. at 21 ; id. at 25 ("The effect of competition is also confirmed with higher LTI [loan-to-income] ratios in MSAs with larger number of competing lenders.").

103. Id. at 16 ("In the subprime mortgage market, denial rates were lower in more competitive markets as measured by the number of competitors in the MSA. This coefficient was, instead, not statistically significant for the prime market."); id. at 21 ; id. at 27 ("[T]he effects we identify for the subprime market are either much weaker or absent in the prime mortgage market, lending additional support that the deterioration in lending standards was more pronounced in the subprime mortgage market. Our evidence suggests that while in the prime market lending standards were largely determined by underlying fundamentals, for subprime loans lending market conditions and strategic interactions played an important role in lending decisions.").

104. Id. at 1,15 .

105. Dell'Ariccia, Igan, and Laeven define the subprime market as consisting of loans originated by lenders listed as subprime lenders by the U.S. Department of Housing and Urban Development (HUD). Id. at 6. This is the same definition of the subprime market used by the GSEs themselves in classifying the overwhelming majority of their loans as prime. See FCIC REPORT, supra note 74, at 451 n.5 (2011) (dissenting statement of Peter J. Wallison). 
underwriting standards by exercising greater control over the originators who supplied them with loans.

\section{F. GSE Underwriting Remained More Conservative than Average}

High market share and a high degree of centralized control over underwriting appear to be associated with more conservative underwriting. Both underlying loan performance data and financial market prices for packaged securities suggest that the GSEs maintained higher underwriting standards than most other secondary market actors. ${ }^{106}$

Loan performance data compiled by Freddie Mac's Office of the Chief Economist ${ }^{107}$ suggest that the GSEs were in fact more successful than almost any other secondary market actor in maintaining high standards in the individual loans that they purchased. The data also suggest that the FHA and VA-though not as successful as the GSEs - were more successful than the average private label securitizers and also more successful than banks and thrifts that retained loans in their portfolios.

The data are current as of December 31, 2010, and were compiled by Freddie Mac from sources including the Mortgage Bankers Association National Delinquency Survey, Federal Reserve Board Flow of Funds Data, FHA and VA monthly reports, Freddie Mac's most recent annual 10-K report, Fannie Mae's Fourth-Quarter 2010 Credit Supplement, Core Logic LoanPerformance data, the Federal Deposit Insurance Corporation (FDIC), and the NCUA. Data is presented in Figure 11.

106. See, e.g., IMMERGLUCK, supra note 4, at 211.

107. Although Freddie Mac is an interested party, the credibility of its data is bolstered by its consistency with financial market assessments of relative losses and analyses conducted by the Financial Crisis Inquiry Commission. It is also consistent with data compiled by the GSEs' regulator. Fed. Housing Fin. Agency, ForeClosure Prevention \& Refinance Report Third Quarter 2011, at 4 (2011); Fed. Housing Fin. Agency, Data on the Risk Characteristics and Performance of Single Family Mortgages Originated from 2001 through 2008 and Financed in the Secondary Market 27 (2010). 
Figure 11: GSEs loan performance was better than private securitizers and even traditional depository institutions

\section{Seriously Nonperforming Loans, Dec. 31, 2010}

\section{Percent of each entity's loans that are 90+ days deliquent or in foreclosure}

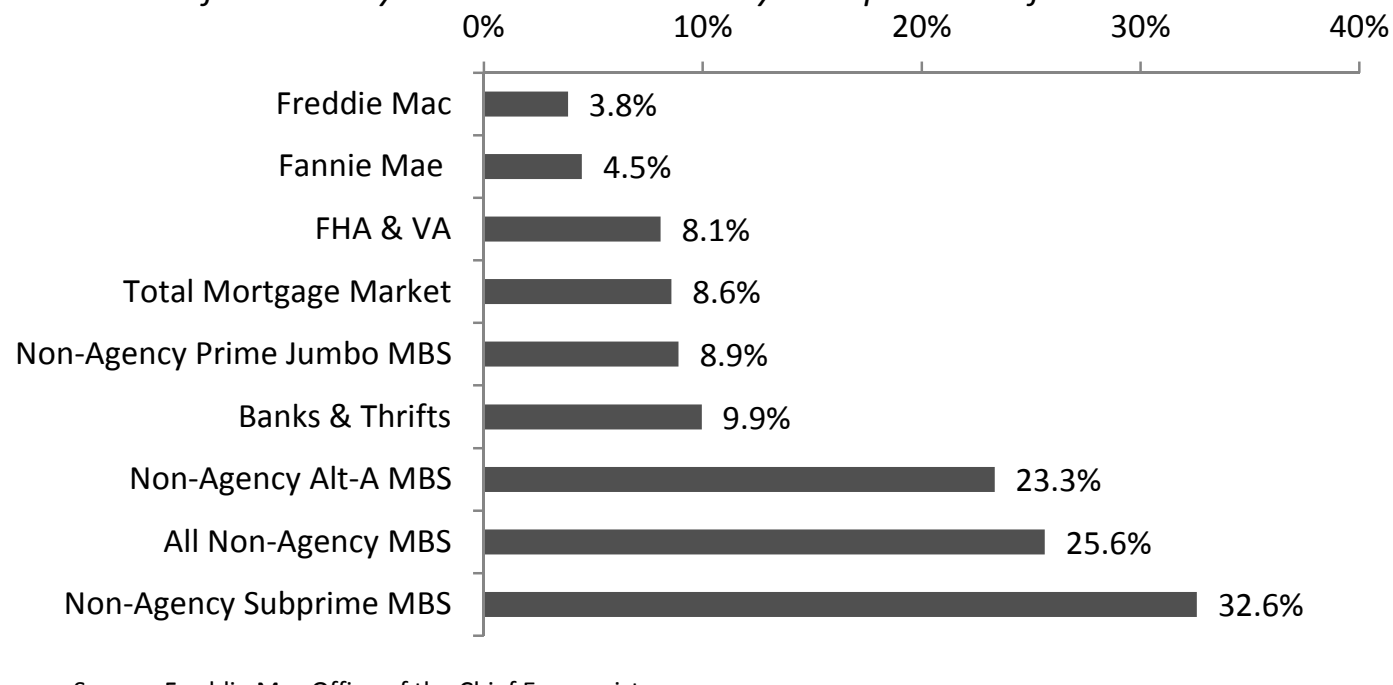

Source: Freddie Mac Office of the Chief Economist

The implication of Freddie Mac's data-that the GSEs were better at quality control than other entities - is broadly consistent with a detailed analysis of loan performance conducted by the Financial Crisis Inquiry Commission (FCIC). In May of 2009, Congress appointed the FCIC to investigate the causes of the financial crisis of $2008 .{ }^{108}$

The FCIC analyzed over twenty-five million mortgages, some of which were purchased or guaranteed by the GSEs, some of which were insured by the FHA or $\mathrm{VA}$, and the remainder of which were Alt-A or subprime mortgages securitized in the private market. ${ }^{109}$

The FCIC found that:

The data illustrate that in 2008 and 2009, GSE loans performed significantly better than privately securitized, or non-GSE, subprime and Alt-A loans. . . . In 2008, the respective average delinquency rates for the non-GSE and GSE loans were $28.3 \%$ and $6.2 \%{ }^{110}$

Like Freddie Mac, the FCIC found that FHA and VA loans performed much better than private label Alt-A and subprime loans, but not as well as GSE loans. ${ }^{111}$

108. FCIC REPORT, supra note 74, at xi.

109. Id. at 216 .

110. Id. at 218-19.

111. Id. at 218 fig.11.3. 
The GSEs' superior performance relative to private label mortgages persists even when controlling for risk factors such as low-borrower FICO scores ${ }^{112}$ or high loan-to-value ratios. ${ }^{113}$ The FCIC attributed the GSEs' performance advantage to "differences in underwriting standards" and to less "risk layering" by the GSEs. ${ }^{114}$ In other words, the GSEs were less likely to combine low FICO scores with high loan-to-value ratios in the same loan.

The FCIC's findings undercut claims by Edward Pinto, a mortgage market consultant who has frequently testified before Congress that the GSEs funded the riskiest mortgages. ${ }^{115}$

The GSEs' superior performance may be due in part to their size and market power, in part to good incentives created by GSE retention of default risk, and perhaps also in part to regulations which limited the GSEs' ability to relax their underwriting standards.

\section{G. Experts Believe that Competition Contributed to Loose Underwriting}

Expert opinions that certain kinds of competition can undermine underwriting standards lend additional support to the quantitative empirical evidence presented above.

One of the major themes of the FCIC's report is that competitive pressures led to greater risk taking and poor mortgage underwriting. The report identifies competition for market share, revenue, and profits between the GSEs ${ }^{116}$ and the private banks ${ }^{117}$ that purchased and securitized mortgages, and similar competition

112. Id. at 218 ("[A]mong loans to borrowers with FICO scores below 660, a privately securitized mortgage was more than four times as likely to be seriously delinquent as a GSE.”).

113. Id. at 219 ("[I]n 2008 among loans with an LTV above $90 \%$, the GSE pools have an average rate of serious delinquency of $5.7 \%$, versus a rate of $15.5 \%$ for loans in private AltA securities.").

114. Id.; see also Fannie Mae and Freddie Mac's Key Role in Subprime Lending: Hearing Before H. Comm. on Oversight and Gov't Reform, 110th Cong. 3-4 (2008) (statement of Edward J. Pinto), available at http:/oversightarchive.waxman.house.gov/documents/20081209145847.pdf (suggesting that many "subprime" loans by loan-to-value ratio or by FICO score were mislabeled as "prime" in many databases).

115. FCIC REPORT, supra note 74, at 218-19 (summarizing Pinto's claims and rejecting his analysis as "misleading"); see also DAVID Min, CTR. For AM. Progress, FAUlty ConClusions BASED ON SHODDY FOUNDATIONS (2011), available at http://www.americanprogress.org/wpcontent/uploads/issues/2011/02/pdf/pinto.pdf; infra Part VI.

116. FCIC REPORT, supra note 74, at xix, 18; id. at 122 ("In 2004, Fannie and Freddie ... were losing market share to Wall Street . . . Struggling to remain dominant, they loosened their underwriting standards, purchasing and guaranteeing riskier loans, and increasing their securities purchases."); see also id. at 178-82 (discussing the debate among managers of the GSEs in 2004 about whether to loosen underwriting standards to preserve market share and profitability, and the ultimate decision to do so); $i d$. at 318 (noting that the GSEs' regulator blamed the GSEs for underpricing risk in order to gain market share and compete with Wall Street banks).

117. Id. at 88 (noting that investment banks began to compete for supplies of subprime loans to feed their securitization machinery); $i d$. at 166 ("Keith Johnson, the president of [a large third-party loan due diligence firm that worked for private securitizers], told the 
between mortgage originators ${ }^{118}$ as causes of risky lending that led to the crisis. The report also describes competition between financial regulators, which reduced those regulators' authority. ${ }^{119}$ The report also describes how competition between credit rating agencies for market share and profits reduced the rating agencies' ability to honestly and diligently evaluate the collateral underlying MBS. ${ }^{120}$ Like the majority

Commission .... that his clients often waived in loans [that did not meet their own underwriting criteria] to preserve their business relationship with the loan originator-a high number of rejections might lead the originator to sell the loans to a competitor. Simply put, it was a sellers' market. 'Probably the seller had more power than the Wall Street issuer,' Johnson told the FCIC."); see also ELLEN ET AL., supra note 72, at 4 ("As a result of this new and aggressive competition from the PLS market, the GSEs saw their market share erode. In response, the GSEs loosened their underwriting guidelines ....").

118. FCIC REPORT, supra note 74, at 20 ("'Poison' was the word famously used by Countrywide's [CEO Angelo] Mozilo to describe one of the loan products his firm was originating. . . . Others at the bank argued in response that they were offering products 'pervasively offered in the marketplace by virtually every relevant competitor of ours."'); id. at 79 (noting that, according to FDIC Chairman Sheila Bair, "'really poorly underwritten loans" originated outside the traditional banking sector, "pulled market share from traditional banks," and "created negative competitive pressure for the banks and thrifts to start following suit"'); $i d$. at 105 ("In 2004, Mozilo announced a very aggressive goal of gaining 'market dominance' . . . . But Countrywide was not unique: Ameriquest, New Century, Washington Mutual, and others all pursued loans as aggressively. They competed by originating types of mortgages created years before as niche products, but now transformed into riskier, mass-market versions."); id. at 108 ("Mentioning . . . competitors, John Stumpf, the CEO, chairman, and president of Wells Fargo, recalled Wells's decision not to write option ARMs . . . . These were 'hard decisions to make at the time,' he said, noting 'we did lose revenue, and we did lose volume."').

119. Id. at xviii ("[T]he government permitted financial firms to pick their preferred regulators in what became a race to the weakest supervisor."); id. at 94-95 ("Greenspan and other [Federal Reserve] officials were concerned that routinely examining the nonbank subsidiaries could create an uneven playing field because the subsidiaries had to compete with the independent mortgage companies, over which the Fed had no supervisory authority .....); id. at 154 ("[According to] Mark Olson, a Fed governor from 2001 to 2006[,] 'There was a lot of competitiveness among the regulators.' In January 2008, Fed staff had prepared an internal study to find out why none of the investment banks had chosen the Fed as its consolidated supervisor. ... [T] he biggest reason firms opted not to be supervised by the Fed was the 'comprehensiveness' of the Fed's supervisory approach, 'particularly when compared to alternatives such as Office of Thrift Supervision (OTS) or Securities \& Exchange Commission (SEC) holding company supervision."); id. at 306 ("In an August 2008 interview, William Isaac, who was chairman of the FDIC from 1981 until 1985, noted that the OTS and FDIC had competing interests. . . . FDIC Chairman Sheila Bair underscored this tension, telling the FCIC that 'our examiners, much earlier, were very concerned about the underwriting quality of WaMu's mortgage portfolio, and we were actively opposed by the OTS in terms of going in and letting our [FDIC] examiners do loanlevel analysis."') (alteration in original).

120. Id. at $\mathrm{xxv}$ ("[T] he forces at work behind the breakdown at Moody's [Investor Service, one of the three major rating agencies, included] . . pressure from financial firms that paid for the ratings, the relentless drive for market share, [and] the lack of resources to do the job despite record profits ...."); id. at 206-12; id. at 210 ("[T] share, combined with complacency, may have deterred Moody's from creating new models or updating its assumptions ...."); id. ("Richard Michalek, a former Moody's vice president and senior credit officer, testified to the FCIC, 'The threat of losing business to a competitor, even if not realized, absolutely tilted the balance away from an independent arbiter of risk towards a captive facilitator of risk transfer.' [Gary] Witt [, a former Managing Director at 
report, the FCIC dissenting report by Peter J. Wallison identifies competition for loans as a cause of poor underwriting, although the dissent claims that the competition for loans was driven by government affordable housing policies rather than the pursuit of revenue, market share, and profit. ${ }^{121}$

\section{CONCENTRATED MARKET STRUCTURES WORK WELl IN OTHER COUNTRIES}

Additional evidence that concentrated mortgage securitization markets tend to be more stable than fragmented, competitive ones can be found in foreign mortgage markets. Advocates of U.S. mortgage market reform have noted mortgage market stability and high home ownership rates in select western European countries that use covered bonds. ${ }^{122}$ The European model shares many features with the U.S. GSE model — both models involve large financial institutions, which select and back mortgages, which have implied guarantees from their respective governments, and whose ability to relax underwriting standards is limited by regulation. ${ }^{123}$ However, unlike the U.S. GSEs, European institutions did not face competition from more lightly regulated private label securitizers. ${ }^{124}$ The covered bond model might not be workable in a competitive, lightly regulated market. In the United States, different variations of this model have been tried but have failed. ${ }^{125}$

European covered bonds are similar to all securitization in that investors have first priority claims on a particular set of loans. European covered bonds are similar to GSE securitizations - and different from most U.S. private label securitizations - in that investors have recourse not only to the loans backing the

Moody's,] agreed. When asked if the investment banks frequently threatened to withdraw their business if they didn't get their desired rating, Witt replied, 'Oh God, are you kidding? All the time. I mean, that's routine. I mean, they would threaten you all of the time. . . It's like, "Well, next time, we're just going to go with Fitch and S\&P." [Moody's President Brian] Clarkson affirmed that 'it wouldn't surprise me to hear people say that' about issuer pressure on Moody's employees.") (alterations in original); id. at 210-11 (quoting an internal memorandum from October 2007, in which Moody's Chief Credit Officer Andrew Kimball warned that investment banks that issued MBS were "penaliz[ing] quality by awarding rating mandates based on the lowest credit enhancement needed for the highest rating. Unchecked, competition on this basis can place the entire financial system at risk.").

121. See FCIC RePort, supra note 74, at 444, 453-55, 464, 481, 487, 490, 506, 509, 511, 519 (dissenting statement of Peter J. Wallison).

122. Dwight M. Jaffee, Reforming the U.S. Mortgage Market Through Private Market Incentives 11-24 (Fisher Ctr. for Real Estate \& Urban Econ., Working Paper, 2011), available at http://escholarship.org/uc/item/4x0357n0.

123. The primary difference is off-balance-sheet accounting treatment for securitizations versus on-balance-sheet accounting treatment for covered bonds. Michael Lea, Paper Prepared for Harvard Joint Center for Housing Studies National Symposium: Alternative Forms of Mortgage Finance: What Can We Learn from Other Countries? (Feb. 18, 2010), available at $\mathrm{http} / / /$ citeseerx.ist.psu.edu/viewdoc/download?doi=10.1.1.172.5652\&rep=rep1\&type=pdf.

On-balance-sheet accounting treatment might improve regulators' and investors' ability to understand and limit financial institution leverage levels. See generally Simkovic, Secret Liens, supra note 3.

124. Lea, supra note 123, at 21 ("By legislation covered bond issuers must be regulated banks ....").

125. Snowden, Mortgage, supra note 14, at 9-12, 30-32. 
covered bonds or MBS but also to a guarantee from the issuing financial institution. $^{126}$

The most stable foreign markets were characterized by high market concentration and strict, uniform regulation. Within the best performing foreign countries, a few large, vertically integrated financial institutions dominated mortgage underwriting ${ }^{127}$ and therefore either had implicit government guarantees, ${ }^{128}$ or the largest mortgage lenders were state owned. ${ }^{129}$ In many of the best performing foreign markets, a single, powerful regulator supervised all financial institutions that originated, underwrote, and guaranteed mortgages. ${ }^{130}$ Within the best performing countries, individual financial institutions had less flexibility than in the United States to "innovate" by relaxing their underwriting standards. $^{131}$

126. Jaffee, supra note 122 , at 18 .

127. Lea, supra note 123, at 7 ("Mortgage lending tends to be dominated by banks and highly concentrated in most countries. The top five lenders have more than a 50 percent market share in Australia, Canada, Denmark, Netherlands and the UK."); id. at 18 ("The [mortgage credit institutions (MCI)] in Denmark specialize in residential, commercial and agricultural mortgage lending. The market is highly concentrated with $4 \mathrm{MCI}$ providing over 80 percent of the market."); $i d$. at 26 ("[M] ortgage lending in most markets is dominated by large commercial banks. There is some evidence . . . that large lenders avoided the excesses of non-conforming lending due to concerns about reputation risk.").

128. Id. at 21 ("Irish, German and Belgian governments had to step in and rescue covered bond issuers ... . The European covered bond markets were stressed during the crisis. Issuance of jumbo covered bonds . . . . was only restarted in the first quarter of 2009 after the European Central Bank (ECB) announced a purchase program of up to $€ 65$ billion. [There were also] widespread government guarantees of bank debt . . . in most countries during the crisis."); InT'L MONetary Fund, DenMark-2010 Article IV Consultation, Concluding Statement of THE Mission (2010) ("The [Danish] banking system was fortified by a wide range of measures, including a blanket government guarantee for depositors and creditors; liquidity support; capital injections; and a temporary bank resolution scheme.").

129. Lea, supra note 123, at 7 ("Banks are the largest lender class in Germany and Spain but the individual institution market shares is much smaller. Savings banks (owned by the state governments) are the largest lenders in these countries ....").

130. Id. at 13 ("The US is unique in its fragmented regulatory structure with numerous specialized regulatory agencies. . . . An advantage to having a single financial sector regulator is the lower likelihood of regulatory capture or regulatory arbitrage ...."); id. at 25 ("The Canadian financial regulatory structure is widely credited with enhancing the stability of the system. The IMF commended the Canadians on their highly effective and nearly unified regulatory and supervisory framework."); $i d$. at 26 ("[T]he decline in underwriting standards inherent in sub-prime lending was responsible for . . . the financial crisis. No other country experienced a similar decline in standards. . . . [N]one created a market with as poor quality loans as the US. . . [ $[\mathrm{N}]$ o other country had as significant a shadow banking system as the US. In all other countries there was greater regulatory oversight of mortgage lending which may have slowed the move to lower standards. Having one financial regulator with responsibility for non-bank as well as bank lenders is an important attribute of regulation.").

131. Id. at 18 ("The underwriting of Danish mortgages is more strict [than] that of the US. The maximum LTV is 80 percent and borrower income is fully documented. . . The Danish system has performed well throughout the crisis. Despite having a larger house price bubble . . . the Danish system has had far fewer defaults . . and foreclosures . . . ."); id. at 24 ("Canada is unique in requiring mortgage insurance on all bank originated mortgages with 
However, it remains unclear how much insight can be gained by comparing foreign mortgage markets to those in the United States because of broad economic, legal, and political differences.

There are large differences between western Europe and the United States that may explain lower default rates in western Europe, including: more extensive social welfare systems, which stabilize household income; ${ }^{132}$ stronger labor protections, which may reduce the risk of sudden unemployment; ${ }^{133}$ much higher household savings rates ${ }^{134}$ and lower household debt levels, ${ }^{135}$ more robust transit networks, which reduce economic vulnerability to oil price shocks; ${ }^{136}$ a more punitive approach to financial institution bailouts, ${ }^{137}$ and more creditor-friendly insolvency and debt collection laws that shift the risk of loose underwriting away from creditors and toward debtors. ${ }^{138}$

LTV $>80$ percent. . . . The maximum LTV is 95 percent . . . .); id. at 27 ("[R]equiring lenders to explicitly consider borrower affordability as is the case in many other countries would have reduced the prevalence of stated income loans and teaser ARMs.").

132. The United States does less than any developed country, except South Korea, to reduce income inequality through its taxation and transfer spending system, and spends relatively little on unemployment and family benefits. ORG. FOR ECON. Co-OPERATION \& Dev., Growing Unequal?: Income Distribution and Poverty in OECD Countries, Country Note: United States (2008), available at http://www.oecd.org/social/socialpoliciesanddata/41528678.pdf; see also INT'L MONETARY FunD, supra note 128 ("Domestic demand was buttressed by large automatic stabilizers ....").

133. Unionization rates in the United States (around 12\%) are much lower than unionization rates in Canada and most of Western Europe. Jelle Visser, Union Membership Statistics in 24 Countries, Monthly LaB. ReV., Jan. 2006. Although the United States has historically had relatively low unemployment, unemployment more than doubled between 2007 and 2009, while western European and Canadian unemployment remained relatively stable. U.S. BUREAU OF LABOR STATISTICS, INTERNATIONAL UNEMPLOYMENT RATES AND EMPloyment IndeXes, SeAsonally ADJUSTED, 2007-2011, at tbl.1, available at http://www.bls.gov/fls/intl_unemployment_rates_monthly.pdf; see also INT'L MONETARY FUND, supra note 128 ("Extended active labor market policies helped contain employment losses, while relatively generous unemployment benefits lessened the social impact.").

134. Ross Harvey, Org. For ECON. Co-OPERATION \& Dev., Comparison of Household SAVing RATios: EuRO AREA/United StATES/JAPAN (2004), available at http://www.oecd.org/dataoecd/53/48/32023442.pdf.

135. EuROPEAN CENT. BANK, supra note 54, at 72-73 ("[H]ouseholds in the euro area display a lower average level of indebtedness. Crucially, the percentage of households with mortgage debt in the lowest quantiles of the income distribution is relatively small ....").

136. Oil Prices and the Economic Downturn: Testimony Prepared for the J. Econ. Comm. of the U.S. Cong., 111th Cong. (2009) (statement of James D. Hamilton) (arguing that an oil price spike in 2007 was an important cause of the recession); ANNE KORIN \& DERON LOVAAS,

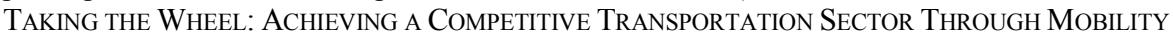
CHOICE (2010), available at http://www.rockefellerfoundation.org/uploads/files/b4960faba604-4e2d-a3a8-96004a067fcc.pdf (discussing the United States' limited transit options and therefore high dependence on oil).

137. Thomas Ferguson \& Robert Johnson, When Wolves Cry "Wolf": Systemic Financial Crises and the Myth of the Danaid Jar, Paper Presented at INET Inaugural Conference at King's College (Apr. 2010), available at http://ineteconomics.org/sites/inet.civicactions.net/files/INET\% 20C@K\%20Paper\%20Session\%208\%20-\%20Ferguson\%20(Rob\%20Johnson)_0.pdf.

138. Jaffee, supra note 122, at 14, 20-21. More creditor-friendly laws are by no means a panacea. See, e.g., Quinn Curtis, Foreclosure Law and Mortgage Risk in the Subprime Era: An Empirical Examination (Jan. 4, 2011) (unpublished manuscript) (reporting looser underwriting in states with more creditor-friendly foreclosure laws). Greater awareness of 


\section{MORTGAGE MARKET PRIVATIZATION INCREASES RISKS TO TAXPAYERS}

The Treasury appears to be concerned about the extent to which the federal government's balance sheet is being used to directly fund the mortgage market. The Treasury recently published a report to Congress, Reforming America's Housing Finance Market ("Treasury Report"), which outlines a plan to "reduce the role of [Fannie Mae and Freddie Mac] in the mortgage market and, ultimately, wind down both institutions."139 The plan calls for restoring market competition by making "private markets . . . the primary source of mortgage credit" and by acting "to eliminate unfair capital, oversight, and accounting advantages and promote a level playing field" for private financial institutions to compete with one another. ${ }^{140}$

The Treasury's motivation appears to be at least partly ideological. The Treasury has decided that its ultimate goal is to reduce the role of government:

There will of course be significant debate ... . But we must be careful not to let that debate keep us from the immediate task at hand: we need to scale back the role of government in the mortgage market, and promote the return of private capital ... The housing finance system must be reformed. ${ }^{141}$

The Treasury has emphasized the importance of the government reducing its market share so that private financial institutions can expand and make greater profits. ${ }^{142}$ According to the Treasury, "[u]nder normal market conditions, the essential components of housing finance-. . . lending money, determining how

the background legal regime among creditors than among borrowers may help explain why creditor-friendly collection laws appear to transfer value from borrowers to creditors without reducing borrowing costs. See Andra C. Ghent \& Marianna Kudlyak, Recourse and Residential Mortgage Default: Evidence from US States, 24 REv. FIN. STUD. 3139 (2011); Michael Simkovic, The Effect BAPCPA on Credit Card Industry Profits and Prices, 83 AM. BANKR. L.J. 1 (2009) (finding that creditor-friendly changes to U.S. bankruptcy laws reduced loan losses to credit-card companies but did not reduce costs for credit-card borrowers). Streamlined foreclosure processes and large numbers of foreclosures can also depress housing prices and trigger more defaults. EUROPEAN CENT. BANK, supra note 54, at 72-73.

139. U.S. Dep'T of the Treasury \& U.S. Dep'T of Hous. \& Urban DeV., Reforming America's Housing FinANCE MARKet: A Report to CONGRess 2 (2011) [hereinafter TREASURY REPORT], available at http://www.treasury.gov/initiatives/Documents/Reforming\%20 America's\%20Housing\%20Finance\%20Market.pdf.

140. Id. at 1 .

141. Id. at 31 (emphasis in original).

142. Id. at 12-13 ("We support ending the unfair capital advantages that Fannie Mae and Freddie Mac previously enjoyed and recommend FHFA require that they price their guarantees as if they were . . . private banks or financial institutions. This will . . help the private market compete on a level playing field, reducing Fannie Mae and Freddie Mac's market share over time."); id. at 13 ("In order to further scale back the [GSEs'] share of the mortgage market, the Administration recommends that Congress allow the temporary increase in limits [on the size of mortgages the GSEs are allowed to purchase and securitize] to expire .... As a result of these reforms, larger loans for more expensive homes will once again be funded only through the private market."); id. at 14 ("As Fannie Mae and Freddie Mac's presence in the market shrinks . . . . we will coordinate reforms . . . to help ensure the private market, not FHA, fills the market opportunities created by reform."). 
best to invest capital, and bearing credit risk — are fundamentally private sector activities." 143

These statements reflect a normative preference that the government play a limited role in mortgage finance. ${ }^{144}$ However, the claim that mortgage finance consists of "fundamentally private sector activities" is hardly an accurate description of how mortgage finance has functioned in the United States for the last seventy years. ${ }^{145}$

The Treasury has suggested that winding down the GSEs and reducing the government's role in the mortgage market would protect taxpayers. ${ }^{146}$ Contrary to the Treasury's claims, the analysis presented here suggests that residential mortgage market privatization along the lines envisioned by the Treasury would put taxpayers at greater risk.

\section{A. Private Competition Leads to More Failures and "Bailouts"}

As discussed above, a fragmented, competitive, privatized mortgage market leads financial institutions to take greater risks and makes financial crises more likely. The government cannot credibly commit in advance to refrain from bailing out financial institutions during the next crisis.

In 2008 the federal government "bailed out" GSEs (which had been private for almost forty years) and many other large private financial institutions ${ }^{147}$ - or to be more precise, those institutions' creditors and shareholders.

Under non-bailout insolvency resolution mechanisms such as bankruptcy, shareholders are wiped out and many creditors incur losses, but the institution itself

143. Id. at 12 .

144. The Treasury's view is not that the government should play no role whatsoever. The Treasury has suggested that the government should remain active as a regulator protecting borrowers and investors, possibly to provide "targeted" subsidies to low-income borrowers and possibly as a lender of last resort in times of crisis. Id. at 1, 27-30. However, in the Treasury's view, government generally should not provide funding in the ordinary course, as the GSEs do now.

145. See supra Part II.

146. TREASURY REPORT, supra note 139 , at 25-26, 31.

147. See Arthur E. Wilmarth, Jr., The Dark Side of Universal Banking: Financial Conglomerates and the Origins of the Subprime Financial Crisis, 41 ConN. L. REv. 963, 1043-46 (2009) (arguing that large banks and finance firms were the epicenter of the financial crisis). The most salient bailouts were of Citigroup, Bear Stearns, AIG, the GSEs, and many investment and commercial banks through the Troubled Asset Relief Program (TARP). However, there were also less transparent mechanisms used to assist many more financial institutions, such as paying AIG's CDS counterparties one hundred cents on the dollar rather than negotiating haircuts, allowing Goldman Sachs and Morgan Stanley to convert to bank holding companies and borrow from the Federal Reserve, extensive purchases of commercial paper and discount lending by the Federal Reserve, debt and asset guarantees, and relaxation of mark-to-market accounting. See Cong. Oversight Panel, MARCH OVERSIGHT REPORT 16-45 (2011) (discussing the many government interventions in response to the financial crisis); Adam J. Levitin, In Defense of Bailouts, 99 GEO. L.J. 435, 437 (2011) (discussing the lack of transparency in the government's response to the financial crisis); Saule T. Omarova, From Gramm-Leach-Bliley to Dodd-Frank: The Unfulfilled Promise of Section 23A of the Federal Reserve Act, 89 N.C. L. REV. 1683, 1729-62 (2011) (discussing the many regulatory exemptions granted in the wake of the financial crisis). 
may be reorganized and continue to function if it can obtain postpetition financing. A number of bankruptcy scholars have argued that bailouts often relate less to the future operation of an institution - liquidation vs. reorganization - than to who will incur losses that have already been realized. ${ }^{148}$ To the extent that this is true, bailouts may be driven by political considerations rather than economic necessity.

Whether bailouts are driven by politics or true economic necessity, they generally function as a mechanism for transferring losses from private investors and other creditors to taxpayers.

The 2008 mortgage crisis was not the first time the U.S. government (or the Federal Reserve) "bailed out" private financial institutions. Other notable bailouts have included: elite financial institutions in the late 1920s and early 1930s after the Great Crash ${ }^{149}$ Franklin National Bank in 1974, Continental Illinois National Bank and Trust Company in 1984, and most of the savings and loan industry and their exhausted insurance fund in $1989 .{ }^{150}$ Furthermore, the United States is not unique in its proclivity for bailouts: since World War II many other governments have bailed out their financial sectors. ${ }^{151}$

Financial markets expect that the U.S. government will continue to bail out large, private financial institutions on favorable terms. Because these institutions enjoy an implied government guarantee, investors are willing to lend them money at lower rates than their smaller competitors. ${ }^{152}$

148. See, e.g., Kenneth Ayotte \& David A. Skeel, Jr., Bankruptcy or Bailouts?, 35 J. CORP. L. 469, 476-83, 498 (2010) (arguing that bankruptcy can be an effective resolution mechanism for financial institutions and is at times preferable to bailouts); Levitin, supra note 147, at 440 (arguing that bailouts are orchestrated to reduce the impact of a firm's failure on its creditors); Stephen J. Lubben, Systemic Risk and Chapter 11, 82 TEMP. L. REV. 433, 442-47 (2009) (arguing that Chapter 11 Bankruptcy could function as an effective resolution mechanism for financial institutions if exceptions for derivatives were scaled back).

149. Simon Johnson \& James KwaK, 13 Bankers: The Wall Street Takeover and the Next Financial Meltdown 30 (2010).

150. See Ayotte \& Skeel, supra note 148, at 497-98 (arguing that regulators "invariably" bail out systemically important banks); Levitin, supra note 147, at 448 (discussing the Federal Home Loan Bank Board's decision to modify requirements for the Savings and Loan industry in 1982); Michael M. Phillips, The Financial Crisis: Government Bailouts - A U.S. Tradition Dating to Hamilton, Wall St. J., Sept. 20, 2008, at A3; Jesse Nankin, Eric Umansky, Krista Kjellman \& Scott Klein, History of U.S. Gov't Bailouts, ProPuBlica (Apr. 15, 2009), http://www.propublica.org/special/government-bailouts; Nelson D. Schwartz, $A$ History of Public Aid During Crises, N.Y. TIMES, Sept. 7, 2008, at A27.

151. See Carmen M. Reinhart \& Kenneth S. Rogoff, This Time Is Different: Eight Centuries of Financial Folly 163-64, 166, 171 (2009).

152. See Johnson \& KwaK, supra note 149, at 12; Edward J. Kane, Extracting Nontransparent Safety Net Subsidies by Strategically Expanding and Contracting a Financial Institution's Accounting Balance Sheet, 36 J. FIN. SERVICES RES. 161 (2009); Arthur E. Wilmarth, Jr., Reforming Financial Regulation to Address the Too-Big-To-Fail Problem, 35 BRooK. J. INT'L L., 707, 742-43 (2010) [hereinafter Wilmarth, Too-Big-ToFail]; Wilmarth, supra note 147, at 1049-50; Deniz Anginer \& A. Joseph Warburton, The End of Market Discipline? Investor Expectations of Implicit State Guarantees (Working Paper, 2011), available at http://ssrn.com/abstract=1961656; Emilios Avgouleas, The Reform of 'Too-Big-To-Fail' Bank: A New Regulatory Model for the Institutional Separation of 'Casino' from 'Utility' Banking 5-6 (Working Paper, 2010), available at 
For these reasons and many others, few scholars believe that the government can credibly forswear bailing out private financial institutions in the event of a future financial crisis. ${ }^{153}$ And most scholars believe that another financial crisis is inevitable, notwithstanding recent financial reforms. ${ }^{154}$

In the event of a crisis, the absence of a government-controlled alternative to private financial institutions would make government bailouts of systemically important financial institutions even more likely, and perhaps inevitable. ${ }^{155}$

While a great deal of attention has been paid to the problem of "Too Big to Fail" institutions, traditional banking regulation and FDIC deposit insurance essentially assumes that every banking institution is too big to fail- that is, important creditors of even small mortgage lending institutions must be shielded from losses to prevent bank runs and contagion. The problem, therefore, may not be one of minimizing institutional size but rather one of maximizing systemic stability.

\section{B. Lender-of-Last-Resort Programs Transfer Cyclical Losses to Taxpayers}

Mortgage default risk is highly cyclical. ${ }^{156}$ During times of general distress, all loans, not just "risky" loans, become much more likely to default. During boom

http://ssrn.com/abstract=1552970; Santiago Carbo-Valverde, Edward J. Kane \& Francisco Rodriguez-Fernandez, Safety-Net Benefits Conferred on Difficult-To-Fail-and-Unwind Banks in the US and EU Before and During the Great Recession (Nat'l Bureau of Econ. Research, Working Paper No. 16787, 2011), available at http://ssrn.com/abstract=1759859; Erik Devos, Srinivasan Krishnamurthy \& Rajesh Narayanan, The Competitive Consequences of Size in Banking: Evidence from Megabank Mergers 7 (Working Paper, 2010), available at http://ssrn.com/abstract=1571617 (arguing that large bank mergers are driven by opportunities to shift losses to government safety nets rather than operational efficiencies).

153. See Jeffrey N. Gordon \& Christopher Muller, Confronting Financial Crisis: DoddFrank's Dangers and the Case for a Systemic Emergency Insurance Fund, 28 YALE J. ON REG. 151, 155 (2011); Edward J. Kane, Missing Elements in US Financial Reform: A Kübler-Ross Interpretation of the Inadequacy of the Dodd-Frank Act, 36 J. BANKING \& FIN. 654 (2012); Levitin, supra note 147, at 483-84; Omarova, supra note 147, at 1760-69; Mark J. Roe, The Derivatives Market's Payment Priorities as Financial Crisis Accelerator, 63 Stan. L. Rev. 539, 585-87 (2011); Michael Simkovic, Paving the Way for the Next Financial Crisis, BANKIng \& Fin. SERVICES POL'y ReP., March 2010, at 1, 5; Arthur E. Wilmarth, Jr., The Dodd-Frank Act: A Flawed and Inadequate Response to the Too-Big-toFail Problem, 89 OR. L. REv. 951, 986-88 (2011) [hereinafter Wilmarth, Dodd-Frank]; Arthur E. Wilmarth, Jr., The Transformation of the U.S. Financial Services Industry, 19752000: Competition, Consolidation, and Increased Risks, 2002 U. ILL. L. REV. 215, 300-312 (2002); David A. Skeel, Jr., The New Financial Deal: Understanding the Dodd-Frank Act and Its (Unintended) Consequences 8-10 (Univ. Pa. Inst. for Law \& Econ., Research Paper No. 10-21, 2010), available at $\mathrm{http}: / / \mathrm{ssrn} . \mathrm{com} / \mathrm{abstract}=1690979$.

154. See, e.g., Levitin, supra note 147, at 477; Omarova, supra note 147, at 1688-91; Gordon \& Muller, supra note 153, at 4; Skeel, supra note 153, at 3.

155. TREASURY REPORT, supra note 139, at 28 ("A related risk would exist if investors believe that the government would inevitably step in to save whatever private financial institutions or banks have become necessary to maintain the flow of mortgage credit.").

156. See Karl E. Case \& Robert J. Shiller, Mortgage Default Risk and Real Estate Prices: The Use of Index-Based Futures and Options in Real Estate, 7 J. OF Housing RES. 243 (1996); W. Miles, Boom-Bust Cycles and the Forecasting Performance of Linear and Non-Linear Models of House Prices, 36 J. ReAl Est. Fin. \& ECON. 249 (2008); Alan G. Ahearne, John Ammer, Brian M. Doyle, Linda S. Kole \& Robert F. Martin, House Prices and Monetary Policy: A Cross-Country Study (Bd. of Governors of the Fed. Reserve Sys., Int'l Fin. Discussion 
periods, all loans, including risky loans, are much less likely to default. The cyclicality of default risk is illustrated well by Figure 12 below.

Figure 12 shows that although prime loans perform better than subprime loans and although fixed rate mortgages (FRMs) generally perform better than adjustable rate mortgages (ARMs), all loans performed much better during the boom period from late 2003 until mid-2006 than they did before or after.

In fact, the cyclicality is so pronounced that risky subprime mortgages performed better during the 2004 to 2006 boom period than "safe" adjustable rate prime mortgages performed during the crisis from late 2008 on.

\section{Figure 12: Default risk is cyclical across loan classes}

\section{Seriously delinquent loans by class, 2002-2011 \\ Percent of loans seriously delinquent, not seasonally adjusted}

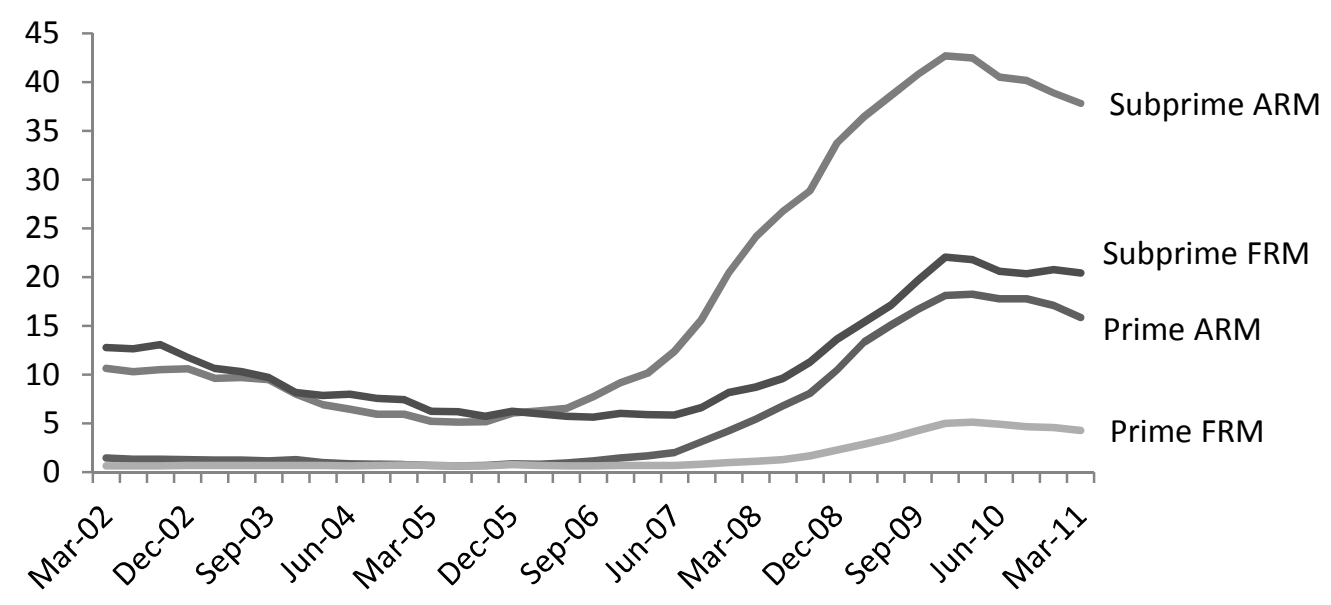

Source: Mortgage Bankers Association, Bloomberg

In light of the cyclicality of default risk, proposals that the government withdraw except as a limited lender of last resort could be rephrased as follows: during prosperous times when unemployment is low, defaults are rare, and mortgage lending is highly profitable, the government will price itself out of the market and allow the profitable business of mortgage funding to be dominated by private financial institutions. During shocks to the economy when unemployment and

Paper No. 841, 2005), available at www.federalreserve.gov/pubs/ifdp/2005/841/ifdp841.pdf; Michael D. Bordo \& Olivier Jeanne, Boom-Busts in Asset Prices, Economic Instability, and Monetary Policy (Nat'l Bureau of Econ. Research, Working Paper No. 8966, 2002); Elul et al., supra note 65, at 7 (arguing that levels of equity and liquidity are "significantly associated with mortgage default"). Similarly, default risks on corporate bonds are known to be cyclical. See Michael Simkovic \& Benjamin S. Kaminetzky, Leveraged Buyout Bankruptcies, the Problem of Hindsight Bias, and the Credit Default Swap Solution, 2011 Colum. Bus. L. Rev. 118, 193-97 (2011). 
default risk are high, the government will rush in to guarantee loans at rates that are below what any private investor would demand.

Private financial institutions have historically proven adept at converting emergency safety nets into ordinary course subsidies. Although the GSEs experienced steep losses from 2007 to $2010,{ }^{157}$ they were highly profitable during the sixteen years from 1990 to 2006 and paid private investors tens of billions of dollars in dividends, as shown in Figure 13. And because the GSEs were highly leveraged, private shareholders captured substantial upside while putting minimal capital at risk, as shown in Figure 14.

A number of studies have suggested that a significant portion of the GSEs' profitability was due to their implied government guarantee. ${ }^{158}$ An implied guarantee enabled the GSEs to borrow cheaply even though they were highly leveraged, because creditors expected taxpayers instead of private capital to absorb any loss. ${ }^{159}$ Had these profits gone to benefit taxpayers - the largest holders of residual risk-instead of private investors-who absorbed limited lossestaxpayers would be in a better position today.

157. According to the companies' financial statements, their aggregate net loss in those years exceeded $\$ 200$ billion, largely due to provisions for loan losses (write downs of nonperforming assets). A number of scholars have suggested that most of these losses were due to write-downs of private label MBS purchased from non-GSE securitizers and held on their balance sheets, but reports from the GSEs' conservator appear to suggest that most of the losses were due to guarantees of poor quality mortgages that originated in 2006 and 2007. Fed. Hous. Fin. Agency, Conservator's Report on the Enterprises' Financial Performance, Second QuARter 20103 (2010); see also Belsky \& Richardson, supra note 53, at 5-8; ELLEN ET AL., supra note 72, at 10; Dwight M. Jaffee, Reforming the U.S. Mortgage Market Through Private Market Incentives 9 (Nov. 15, 2010) (Conference Draft), available at http://research.stlouisfed.org/conferences/gse/Jaffee.pdf; Jason Thomas \& Robert Van Order, A Closer Look at Fannie Mae and Freddie Mac: What We Know, What We Think We Know and What We Don't Know 1 (Mar. 2011) (unpublished manuscript), available at http://business.gwu.edu/creua/research-papers/files/fannie-freddie.pdf.

158. See, e.g., Cong. Budget Office, Federal Subsidies And the Housing GSEs 1 (2001) (noting that the special legal status of Fannie Mae and Freddie Mac as GSEs "enhances the perceived quality of the debt and mortgage-based securities . . that they issue or guarantee and translates into a federal subsidy."); W. Scott Frame \& Lawrence J. White, Fussing and Fuming over Fannie and Freddie: How Much Smoke, How Much Fire?, J. ECON. PERSP., Spring 2005, at 159, 164 ("Evidence suggests that financial markets believe that the federal government would come to the rescue of Fannie Mae and Freddie Mac (and hence their creditors) in the event of financial difficulties. As a result of this perceived implicit guarantee, Fannie Mae and Freddie Mac can typically borrow at interest rates that are more favorable than [their stand-alone rating]."); Wayne Passmore, The GSE Implicit Subsidy and the Value of Government Ambiguity, 33 REAL EsT. ECON. 465, 466 (2005) ("Fannie Mae's and Freddie Mac's ambiguous relationship to the government imparts an implicit subsidy to GSE shareholders and homeowners.").

159. Frame \& White, supra note 158, at 174 ("Because of the implied guarantee, creditors do not monitor the firms' activities as closely as they otherwise would. As a consequence of this reduced monitoring, the managements of Fannie Mae and Freddie Mac can engage in activities that involve greater risk (with greater liability consequences for the government), since the companies' owners will benefit from the 'upside' outcomes while being buffered (because of the limited liability of corporate owners) from the full consequences of large 'downside' outcomes."). 
Figure 13: GSEs were profitable in the decade and a half before the financial crisis and paid substantial dividends

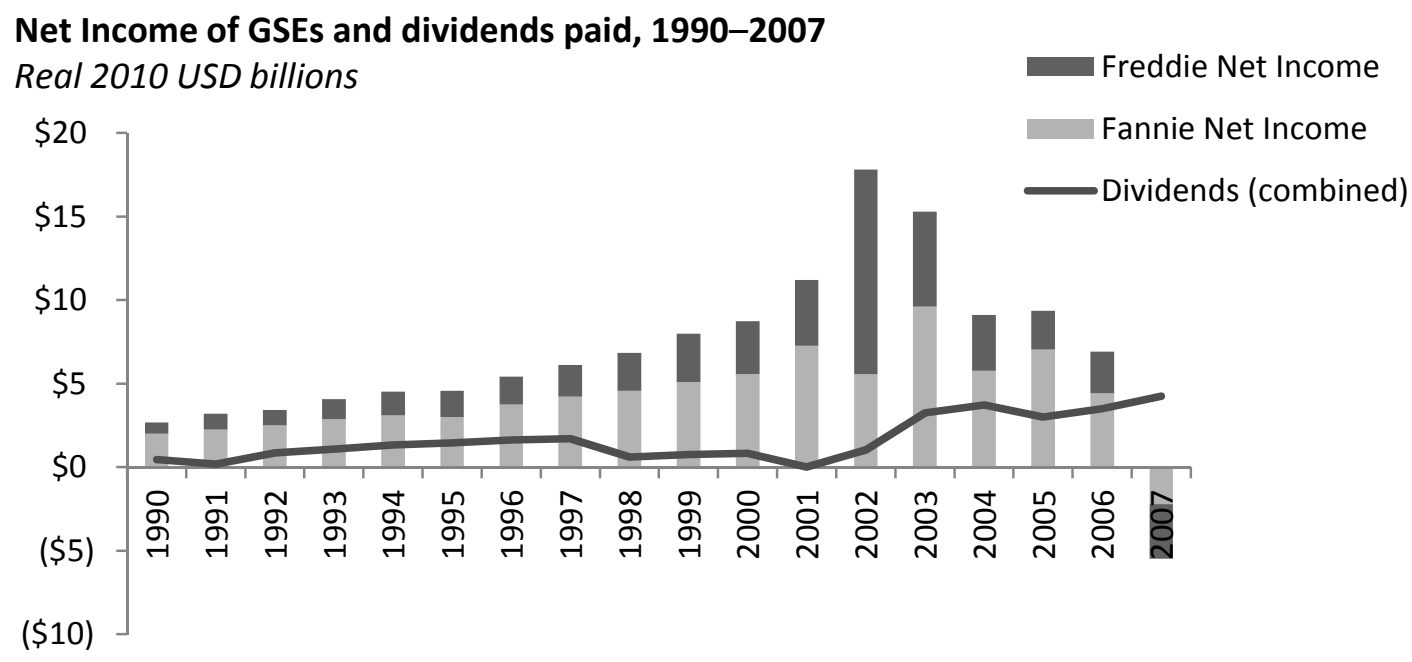

Note: Dividends include dividends paid to both common and preferred equity holders.

Source: Bloomberg Professional Service, Most Recent Company Financial Statements; Bureau of Labor Statistics

Figure 14: GSEs' shareholders captured outsized returns while risking minimal capital

GSE equity capitalization and return on equity, 1990-2007

Common Equity / Total Assets, Percent

Return on Common Equity, Percent

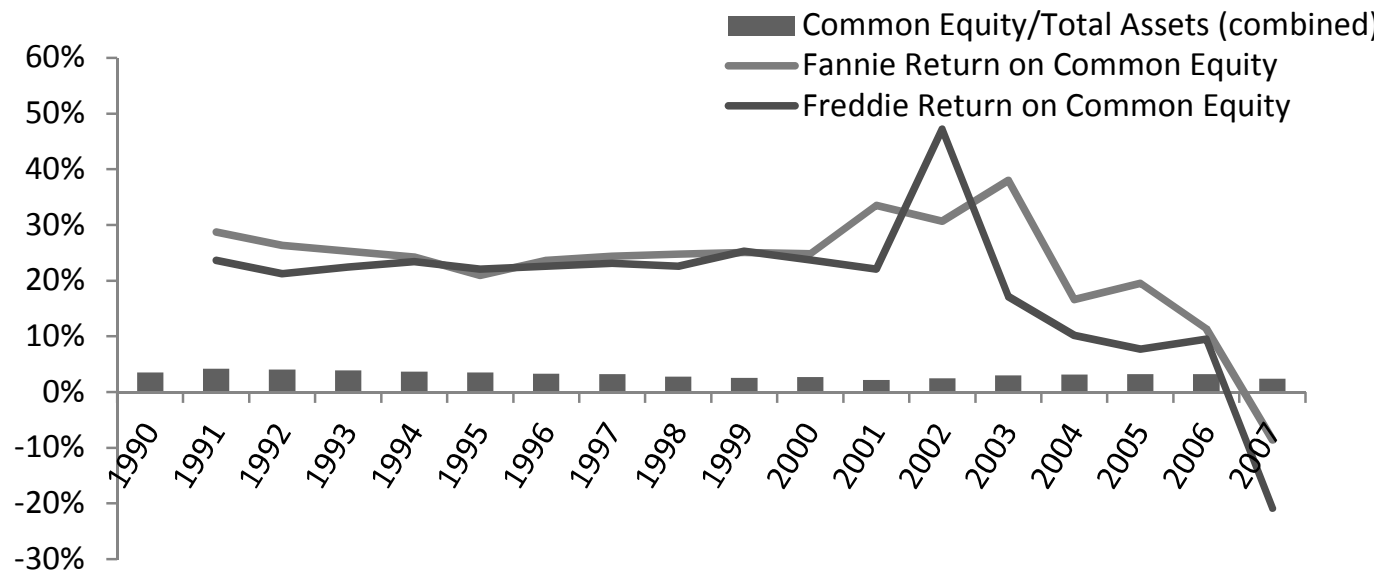

Note: Return on Common Equity is calculated as trailing 12 month Net Income (Losses) minus trailing 12 month Cash Preferred Dividends, divided by the average of the start and end balance of Total Common Equity (share capital and additional paid in capital plus retained earnings.)

Source: Bloomberg Professional Service, Most Recent Company Financial Statements 
GSEs are not the only financial institutions that extracted transfers from taxpayers. Many other financial institutions have also converted safety nets into subsidies.

Professor Saule Omarova has demonstrated that since the passage of the Gramm-Leach-Bliley Act and for a decade before the financial crisis of 2008 , the Federal Reserve Board repeatedly authorized large private financial institutions to subsidize their lightly regulated, high-risk subsidiaries through their governmentbacked, regulated, deposit-taking subsidiaries by suspending the restrictions of section $23 \mathrm{~A}$ of the Federal Reserve Act. ${ }^{160}$

Government guarantees and subsidies earmarked to stabilize a limited set of systemically important financial activities "leaked" through "firewalls" and were used - with the Federal Reserve's authorization - to enhance private financial institutions' profitability. ${ }^{161}$ Rather than being used to stabilize firms through a short-term injection of liquidity, these subsidies were used by private financial institutions to take greater risks at taxpayers' expense. ${ }^{162}$

Implicit or explicit government guarantees to private financial institutions perpetuate a system in which safety net subsidies flow to private financial institutions, while taxpayers continue to take on large downside risk with little upside potential. On the other hand, if the government could participate more actively in the mortgage funding market during normal times, it might recapture the subsidies that now flow to private investors. ${ }^{163}$

\section{Reinsurance Adds Agency Cost and Complexity}

The Treasury's privatization proposals include a hybrid model with the government reinsuring private mortgage insurance companies. Like the GSEs, government-backed private mortgage insurers (GB-PMIs) would have incentives to maximize short-term profits for the benefit of executives and private shareholders. The GB-PMIs could, for example, underprice insurance to chase market share and increase revenue while paying out accounting "profits" as dividends and compensation. In other words, GB-PMIs could easily maximize "profits" by increasing long-term risks to government guarantors.

Positioning the government at the reinsurance level exacerbates information asymmetries and thereby puts the government at a disadvantage. Rather than analyzing and evaluating simple individual mortgage loans prior to guaranteeing them and tracking the performance of particular mortgage originators - as the GSEs do now-the government would be limited to evaluating the aggregated creditworthiness of six huge insurers, each exposed to the risk of millions of mortgages in complex ways governed by the provisions of insurance and reinsurance contracts.

Prior to the financial crisis, many professional investors poorly evaluated mortgage credit risk when it was placed in similarly complicated, aggregated

160. Omarova, supra note 147, at 1700-24.

161. Id. at 1700-56. Professor Omarova documents guarantee leakage both before and during the financial crisis.

162. Id. at $1724-25$.

163. See, e.g., IMMERGLUCK, supra note 4, at 215. 
packages such as private mortgage-backed securities, ${ }^{164}$ collateralized debt obligations, ${ }^{165}$ and credit default swaps on collateralized debt obligations. ${ }^{166}$ Similarly, the GSEs suffered far higher loss rates from the private MBS they purchased and retained on their balance sheet than from individual mortgage loans that they packaged and guaranteed. ${ }^{167}$ There is little reason to believe that the government would fare well today when faced with the complexity and opacity inherent in reinsurance.

Placing the government at the primary insurance level, where the government could analyze individual loan data-the position currently occupied by the FHA, VA, Ginnie Mae, and the GSEs - would substantially simplify credit analysis and risk management. ${ }^{168}$ The institutional ability to analyze loans in granular detail would also reduce the government's dependence on private financial institutions and thereby reduce those institutions' ability to extract bailouts.

\section{Government Pressure Probably Did Not Drive LoOSE UnderWriting}

To the extent that academics have cited government policy as a cause of the financial crisis, they have generally focused on federal preemption of state antipredatory lending laws, failures to strengthen or enforce existing consumer protection laws or adequately inspect mortgage lenders, and other lapses and

164. See Ellen et AL., supra note 72, at 4; Adam J. Levitin \& Susan M. Wachter, Information Failure and the U.S. Mortgage Crisis, in The AMERICAN MORTGage System: CRISIS AND REFORM 243, 243 (Susan M. Wachter \& Marvin M. Smith eds., 2011) (" $[\mathrm{M}]$ arkets failed to price risk correctly because of an informational failure, caused by the complexity and heterogeneity of private-label mortgage-backed securities . . . ."); Joshua Coval, Jakub Jurek \& Erik Stafford, The Economics of Structured Finance, J. Econ. PersP., Winter 2009, at 3; Adam J. Levitin \& Susan M. Wachter, Explaining the Housing Bubble, 100 GEO. L.J. 1177 (2011).

165. See FCIC REPORT, supra note 74, at 18, 190-212; Anna Katherine Barnett-Hart, The Story of the CDO Market Meltdown: An Empirical Analysis 13-15 (March 19, 2009) (unpublished B.A. thesis, Harvard University), available at http://www.hks.harvard.edu/m$\mathrm{rcbg} /$ students/dunlop/2009-CDOmeltdown.pdf.

166. See Robert P. Bartlett, III, Inefficiencies in the Information Thicket: A Case Study of Derivative Disclosures During the Financial Crisis, 36 J. CORP. L. 1 (2010) (finding that investors in monoline insurers failed to react to credit downgrades of collateralized debt obligations (CDOs) to which the monoline insurers were exposed); Kristin N. Johnson, Things Fall Apart: Regulating the Credit Default Swap Commons, 82 U. Colo. L. Rev. 167, 192 (2011); Judge, supra note 4, at 681-86; Simkovic, Secret Liens, supra note 3, at 273-74 (discussing analytic challenges of analyzing CDS on CDOs, even with full disclosure); $i d$. at 283-87 (showing that even highly sophisticated investment banks failed to accurately judge AIG's mortgage risk exposures); Michael Simkovic, Bankruptcy Immunities, Transparency, and Capital Structure, Presentation Before the World Bank Task Force, Bankruptcy Treatment of Financial Contracts (Jan. 11, 2011), http://ssrn.com/abstract=1738539 (same).

167. See FCIC REPORT, supra note 74, at 123, 316; BELSKY \& RiCHARDSON, supra note 53; ELLEN ET AL., supra note 72, at 5 ("It may simply be true that the GSE risk managers were not able to obtain as much information on the quality of the underlying mortgages backing the securities purchased for the portfolio, thereby increasing uncertainty and exacerbating risks.").

168. Figure 11 above suggests that the GSEs and, to a lesser extent, the FHA and VA were better than average underwriters compared to most other financial institutions. 
weaknesses in regulation that permitted industry participants to take greater risks and make greater short-term profits. ${ }^{169}$ In other words, scholars have blamed the government for inaction and excessive deference to the industry.

By contrast, some commentators have argued that lax underwriting was not caused by regulatory weakness and unfettered profit-seeking but was instead caused by government pressure on financial institutions to promote home ownership among low-income individuals. These commentators generally point to two government policies: the Community Reinvestment Act $^{170}$ (CRA) and affordable housing goals for the GSEs that were established by the Department of Housing and Urban Development (HUD). ${ }^{171}$

\section{A. Industry Has Sought to Defend Itself by Blaming Government}

Arguments that government pressure on private financial institutions caused high-risk mortgage underwriting have generally been made in the context of advocacy paid for by the financial industry. Industry-funded research on legal or economic policy issues must be carefully scrutinized. Academic journals require authors to disclose funding sources so that readers are alerted to potential biases affecting authors' analyses. ${ }^{172}$ Industry funding of research is affiliated with

169. See Immergluck, supra note 4, at 41-46, 167-96; Lei Ding, Roberto G. Quercia, Carolina K. Reid \& Alan M. White, The Impact of Federal Preemption of State Antipredatory Lending Laws on the Foreclosure Crisis, 31 J. PoL'y ANALYSIS \& MGMT. 367 (2012); Daniel Immergluck, Private Risk, Public Risk: Public Policy, Market Development, and the Mortgage Crisis, 36 Fordham URB. L.J. 447, 465-85 (2009); David Reiss, The Federal Government's Implied Guarantee of Fannie Mae and Freddie Mac's Obligations: Uncle Sam Will Pick Up the Tab, 42 GA. L. REV. 1019, 1033-35 (2008); see also infra note 214 and accompanying text.

170. FCIC REPORT, supra note 74, at 443-44, 524-32 (dissenting statement of Peter J. Wallison) ("[T] he Community Reinvestment Act of 1977 . . . [was one of the] government social policy mandates responsible for the mortgage meltdown and the financial crisis."). Wallison relies heavily on research by Edward Pinto. Id. at 451 n.4. "The CRA was enacted in 1977 to [prevent banks from] denying credit to individuals and businesses in certain neighborhoods without regard to their creditworthiness. The CRA requires [certain depository institutions] to lend, invest, and provide services to the communities from which they take deposits, consistent with bank safety and soundness." Id. at xxvii. The CRA does not apply to mortgage brokers. Id. at 162 .

171. See FCIC REPORT, supra note 74, at 452-54, 487-519 (dissenting statement of Peter J. Wallison).

172. See, e.g., Stanford Law Review, Ethics Policy (August 2012) (on file with Indiana Law Journal) ("All authors must disclose any conflict of interest. This includes any financial interest that may be affected by the results or conclusions in the submission. This also includes any source of outside funding for the submission that may have affected or biased the assumptions, results or conclusions in the submission-e.g., any payment received by an outside organization to complete the work."); Yale Law Journal, Volume 122 Submission Guidelines (2011) (on file with Indiana Law Journal) ("Authors must identify any organizations that provided funding for the research or writing of the manuscript, as well as any personal or family financial interests that might be pertinent to the piece's conclusions."). 
scientifically questionable proindustry conclusions in pharmaceutical research, ${ }^{173}$ nutritional research, ${ }^{174}$ and environmental research. ${ }^{175}$

Many of the most forceful proponents of government pressure as the cause of poor underwriting - such as mortgage consultant Edward Pinto and FCIC dissenting member Peter J. Wallison ${ }^{176}$ - are employed by "think tanks" such as the American Enterprise Institute (AEI), which fundraise based on their efforts to deflect blame for the financial crisis from private financial institutions and which are committed to advocating free market ideology and limited government. ${ }^{177}$ "AEI is governed by a Board of Trustees, composed of leading business and financial

173. See, e.g., Justin E. Bekelman, Yan Li \& Cary P. Gross, Scope and Impact of Financial Conflicts of Interest in Biomedical Research: A Systematic Review, 289 JAMA 454 (2003); Joel Lexchin, Lisa A. Bero, Benjamin Djulbegovic \& Otavio Clark, Pharmaceutical Industry Sponsorship and Research Outcome and Quality: Systematic Review, 326 BMJ 1167 (2003); Sergio Sismondo, How Pharmaceutical Industry Funding Affects Trial Outcomes: Causal Structures and Responses, 66 Soc. SCI. \& Med. 1909 (2008).

174. See Barrie Margetts, Editorial, Stopping the Rot in Nutrition Science, 9 Pub. Health Nutrition 169 (2006); Tommy Boone, Is Sports Nutrition for Sale?, Professionalization EXERCise Physiology Online (July 2004), http://faculty.css.edu/tboone2/asep/IsSportsNutritionForSale.html.

175. The hydrocarbon/energy industry has funded numerous attacks on the science behind global warming, although virtually none of them have survived peer review and virtually all peer-reviewed scientific research supports the theory of man-made global warming. See Ross Gelbspan, The Heat Is On: The Climate Crisis, the Cover-Up, the Prescription (updated ed. 1998); NaOmi Oreskes \& Erik M. Conway, Merchants of Doubt: How a Handful of Scientists Obscured the Truth on IsSUES From Tobacco Smoke to Global Warming (2010); James Lawrence Powell, The Inquisition of Climate Science (2011); Riley E. Dunlap \& Aaron M. McCright, Climate Change Denial: Sources, Actor, and Strategies, in Routledge Handbook of Climate Change AND SOCIETY 240 (Constance Lever-Tracy ed., 2010); Intergovernmental Panel on Climate Change, Climate Change 2007: Synthesis Report 30-39 ("Warming of the climate system is unequivocal .... There is very high confidence that the global average net effect of human activities since 1750 has been one of warming ... . Most of the observed increase in global average temperatures since the mid- $20^{\text {th }}$ century is very likely due to the observed increase in anthropogenic [Green House Gas] concentrations.") (emphasis in original), available at http://www.ipcc.ch/publications_and_data/ar4/syr/en/contents.html.

176. Peter J. Wallison has been affiliated with the American Enterprise Institute (AEI) since the mid-1990s. AEI Shadow Fin. Regulatory Comm., 1999 Annual Report, available at http://www.aei.org/print/1999-annual-report. AEI's 2009 annual report lists Peter J. Wallison as its Arthur F. Burns Fellow in Financial Policy Studies. AEI, 2009 ANNUAL REPORT 21, available at http://aei.org/files/2009/12/18/2009-Annual-Report.pdf. AEI's 2010 annual report lists Edward Pinto as a member of its research staff and a Resident Fellow. AEI, 2010 ANNUAL REPORT, available at http://aei.org/files/1969/12/31/2010Annual-Report.pdf.

177. Why Should I Invest in AEI?, AEI, http://www.aei.org/support/why-should-i-invest-in-aei (encouraging donors to "invest" in AEI because AEI "is promoting market-driven approaches as the solution to our current woes and not their cause"). AEI describes "strengthening free enterprise" as one of its "unchanging ideals." Id. AEI encourages corporations and wealthy individuals to "support AEI" by assuring them that "[a] donation to AEI is fully tax-deductible and is a sound investment in limited government [and] private enterprise." AEI's Organization and Purposes, AEI, http://web.archive.org/web/20110504235222/http://www.aei.org/about. 
executives." ${ }^{178}$ During the five-year period from 2005 to 2009 , the vast majority of its revenues came from annual donations. ${ }^{179}$

AEI's 2009 report trumpeted Wallison and other AEI-funded writers' efforts to deflect blame for the financial crisis from private financial firms and to place the blame for the financial crisis on government policies. ${ }^{180}$ The report also highlighted AEI's ability to influence "Financial Regulation's Future" because of Wallison's role on the FCIC. ${ }^{181}$ The report suggested that Wallison would likely use the opportunity to blame the GSEs for the financial crisis and to combat more comprehensive financial regulation. ${ }^{182}$

AEI's 2010 annual report points out that Wallison, in his role as a dissenting member of the FCIC, did in fact blame government policy for the financial crisis. ${ }^{183}$ The report reiterates Wallison's opposition to regulation and his ability to influence legislation. ${ }^{184}$ Wallison's unwavering efforts to blame GSEs and government policies for the financial crisis were criticized by other members of the FCIC, including fellow Republicans. ${ }^{185}$

The controversial provenance of the claims that government pressure compelled financial institutions to make risky loans against their better judgment does not render these arguments wrong per se, but it does call for close scrutiny. The claims are prima facie implausible in light of the strong performance of GSE loans (and, to a lesser extent, FHA and VA loans) compared to loans in less-regulated private label securitizations. ${ }^{186}$ The claims also seem dubious in light of the fact that as GSE market share contracted and private label securitization grew, vintage loan performance deteriorated. ${ }^{187}$ Furthermore, as will be discussed below, the evidence of a causal connection between government pressure on financial institutions and risky lending by those institutions is weak.

178. Board of Trustees, AEI, http://www.aei.org/about/board-of-trustees. AEI's "National Council"- presumably large individual donors and fundraisers-is also largely comprised of leading financial executives. See National Council, AEI, http://www.aei.org/about/nationalcouncil/.

179. See AEI, 2006 ANNUAL REPORT, available at http://www.aei.org/files/2002/ 12/07/20061220_2006ARweb.pdf; AEI, 2007 ANNUAL REPORT, available at http://www.aei.org/files/2002/12/07/20071227_45600_AEI_LowRes.pdf; AEI, 2008 ANNUAL REPORT, available at http://www.aei.org/files/2002/12/07/20081205_2008AnnualReportweb.pdf; AEI, 2009 ANNUAL REPORT, supra note 176; AEI, 2010 ANNUAL REPORT, supra note 176.

180. AEI, 2009 ANNUAL REPORT, supra note 176, at 2.

181. Id. at 3 .

182. Id. at 3,4 .

183. AEI, 2010 ANNUAL REPORT, supra note 176, at 2.

184. Id. at 2,3 .

185. Louise Radnofsky \& Alan Zibel, Democrats Pounce as Oversight Panel Calls Off Hearing, WALL ST. J. BLogS (July 13, 2011, 1:39 PM), http://blogs.wsj.com/washwire/2011/07/13/democrats-pounce-as-oversight-panel-calls-offhearing/ ("[E]mails show[] Republican commission member Peter Wallison trying to persuade his colleagues to use their positions to help House Republicans overturn the Dodd-Frank financial regulation legislation. . . . Emails exchanged by the other three Republican commissioners and their staffs shows [sic] they thought Mr. Wallison 'overplays' the argument that government housing policy caused the 2008 financial meltdown and they expressed concerns that $\mathrm{Mr}$. Wallison was 'intractable."').

186. See supra Part III.F.

187. See supra Part III.E. 


\section{B. There Is No Evidence that the Community Reinvestment Act Caused the Financial Crisis}

The claim that the CRA caused the financial crisis is not supported by empirical evidence. In his FCIC dissenting opinion, the only data Wallison provides to support this hypothesis is a table showing annual and cumulative dollar volumes of low-income lending to which financial institutions committed from 1977 to 2007. ${ }^{188}$ This table not only fails to establish causation, but it fails to even establish a connection between commitments under the CRA and actual lending activity. Wallison acknowledged that lenders appear to have frequently failed to fulfill their commitments and that the available data makes it "impossible to determine how many loans were actually made under . . CRA commitments." ${ }^{189}$ Furthermore, according to Wallison, even "[w]here these loans are today must necessarily be a matter of speculation." 190 The handful of academic articles suggesting that the CRA might have caused the financial crisis also do not present empirical evidence to support this claim. ${ }^{191}$

There is, however, substantial empirical evidence that the CRA was not a significant cause of the financial crisis. ${ }^{192}$ Empirical studies by two different teams of Federal Reserve economists both suggest that CRA lending accounted for a

188. FCIC REPORT, supra note 74, at 527 tbl.13 (dissenting statement of Peter J. Wallison). Wallison also lists specific commitments by four large banks. Id. at 529 .

189. Id. at 530. Even if one were to assume that the annual commitments contained in Wallison's Table 13 were proportional to CRA lending, there is no correlation with deterioration in underwriting quality. Whereas underwriting standards generally improved from 2000 to 2003, annual commitments increased during this time period. Whereas underwriting standards generally worsened from 2004 to 2007, CRA commitments decreased. See, e.g., supra Figures 7-9 and accompanying text.

190. FCIC REPORT, supra note 74, at 530 (dissenting statement of Peter J. Wallison). Wallison blames the lack of data on what he claims was "the dilatory nature of the Commission's investigation" although he admits that the banks the FCIC contacted "supplied only limited information. They contended that they did not have the information or that it was too difficult to get, and the information they supplied was sketchy at best." Id. The banks also missed deadlines for submissions of materials to the FCIC. Id. Wallison does not explain why private financial institutions-which would presumably be eager to demonstrate that government policies rather than their own failures led to the financial crisis - would fail to timely provide supporting data.

191. See, e.g., Robert Hardaway, The Great American Housing Bubble: Re-Examining Cause and Effect, 35 U. DAYTON L. REv. 33 (2009).

192. See FCIC REPORT, supra note 74, at 72, 219-21; IMMERGLUCK, supra note 4, at $162-66$. 
minority of subprime lending ${ }^{193}$ and that CRA loans performed better than subprime loans that were driven purely by market considerations. ${ }^{194}$

\section{C. "Synthetic" Collateralized Debt Obligations (CDOs) Suggest that Risk Taking Was Market Driven}

Further evidence that subprime lending was driven by market forces rather than government affordable housing policies comes from the existence of a multibilliondollar "synthetic" CDO market. Traditional CDOs were investment vehicles that purchased securitized bonds and were major investors in subprime MBS. Synthetic CDOs provided investors with similar risk exposures but did not actually fund any new mortgages. Rather than purchase MBS and thereby fund mortgages, synthetic CDOs used credit default swaps to enable investors to make side bets on the performance of existing MBS or CDOs. Even if the government was trying to promote affordable housing, it had no reason to play any role in the synthetic CDO market.

These synthetic instruments existed to a large extent because, at the height of the mortgage boom, investor demand for U.S. mortgage exposure exceeded originators' and securitizers' capacity. ${ }^{195}$ It is far more time consuming and labor intensive to originate and aggregate billions of dollars in mortgages than to simply match investors willing to place opposite bets on the performance of existing MBS.

The existence of the synthetic CDO market suggests that investors' appetites for risk exceeded any floor supposedly set by government affordable housing policies.

\section{Mortgage Lenders Lobbied Against Safe-Lending Regulations}

Additional evidence that market forces pushed toward greater risk taking comes from lobbying activity of mortgage lenders. If government pressure were forcing lenders to lend imprudently against their wishes, one would expect the lenders who lobbied most aggressively on issues related to underwriting regulation to receive dispensation that would enable them to have more conservative underwriting

193. See FCIC RePort, supra note 74, at xxvii, 220; Neil Bhutta \& Glenn B. Canner, Did the CRA Cause the Mortgage Market Meltdown?, COMmunity Dividend (Fed. Reserve Bank Minneapolis), Mar. 2009 (finding that 6\% of subprime loans, defined as high-cost loans under HMDA, had any connection to the CRA); Elizabeth Laderman \& Carolina Reid, Lending in Low- and Moderate-Income Neighborhoods in California: The Performance of CRA Lending During the Subprime Meltdown (Fed. Reserve Bank of S.F., Working Paper 2008-05, 2008) (finding that in California, non-CRA-regulated mortgage brokers devoted a higher proportion of their lending to high priced loans than CRA-regulated institutions).

194. Bhutta \& Canner, supra note 193 (finding that loans made by lenders regulated under the CRA in the neighborhoods in which they were required to lend were half as likely to default as similar loans made in the same neighborhoods by independent mortgage originators not subject to the law); Laderman \& Reid, supra note 193, at 20 (finding that loans by CRA-regulated lenders in CRA assessment areas were half as likely to default as similar loans made by independent mortgage companies not subject to CRA, and concluding that "this suggests that the CRA, and particularly its emphasis on loans made within a lender's assessment area, helped to ensure responsible lending, even during a period of overall declines in underwriting standards").

195. FCIC REPORT, supra note 74, at xxiv, 142-46; Barnett-Hart, supra note 165. 
practices. However, the opposite appears to be true- the lenders who lobbied most aggressively had the riskiest underwriting practices and generally lobbied against substantive limits on their ability to take risk. ${ }^{196}$ This suggests that government regulation was for the most part a restraining force that pushed toward more conservative underwriting.

\section{E. HUD Affordable Housing Goals Played at Most a Limited Role}

The argument that HUD affordable housing goals led to greater risk taking may have some merit. The GSEs' failure was due at least in part to losses they suffered on highly rated tranches of nonprime MBS that the GSEs purchased from private securitizers, and which the GSEs held in portfolio on their balance sheets. ${ }^{197}$

Why the GSEs purchased private label MBS remains open to debate, with some contending that the GSEs were attempting to meet affordable housing goals imposed on them by HUD, and others contending that the GSEs purchased these securities because they offered high yields, were highly rated by the rating agencies, and seemed to be a profitable investment that would benefit GSE shareholders. $^{198}$

It may not be possible to ever conclusively determine the GSEs' motivation. But this much is clear: the GSEs made the same mistake that many other buy-side financial institutions made-trusting underwriting at non-GSE securitizers and private label MBS ratings - and those other investors could not have been driven by HUD's affordable housing goals for the GSEs. ${ }^{199}$

196. See Deniz Igan, Prachi Mishra \& Thierry Tressel, A Fistful of Dollars: Lobbying and the Financial Crisis (IMF, Working Paper WP/09/287, 2009) (finding that lenders who lobbied on issues related to substantive regulation of mortgage underwriting engaged in riskier lending than lenders who did not lobby).

197. See supra note 157 . Fannie Mae and Freddie Mac reportedly securitized a very low percentage of Alt-A securitizations (11\% in 2005 and $12 \%$ in 2006) and $0 \%$ of subprime loans. BELSKY \& RICHARDSON, supra note 53, at 7. However, they purchased the highest rated tranches securitized by the private banks. Id. at 5 .

198. See FCIC REPORT, supra note 74, at xxvii ("Based on the evidence and interviews with dozens of individuals involved in this subject area, we determined these [HUD affordable housing] goals only contributed marginally to Fannie's and Freddie's participation in those mortgages."); id. at 123-125; ELLEN ET AL., supra note 72 at 5 ("While it appears that the primary impetus for [the GSEs'] movement into risky, nonprime investments was the higher interest rates that these investments paid, there is considerable debate about whether the GSEs were also motivated by their need to meet the affordability goals mandated by Congress.") (citation omitted); Thomas \& Van Order, supra note 157, at 1 (finding that the GSEs "did build a large portfolio of AAA-rated PLS, probably in response to affordable housing goals"); Dwight M. Jaffee, Testimony Before the FCIC: The Role of the GSEs and Housing Policy in the Financial Crisis 4-5 (Feb. 27, 2010), available at http://fcic-static.law.stanford.edu/cdn_media/fcic-testimony/2010-0227-Jaffee-ppt.pdf.

199. Private institutions including Citi, insurers AIG, Ambac, MBIA, and several European banks all were sufficiently exposed to subprime MBS that they either became insolvent or would likely have become insolvent but for government intervention. See, e.g., Robert P. Bartlett, III, Inefficiencies in the Information Thicket: A Case Study of Derivatives Disclosure During the Financial Crisis, 36 J. CORP. L. 1 (2010); Simkovic, Secret Liens, supra note 3. 
Although the GSEs were large purchasers of private label securities, GSE purchases never constituted a majority of the private label MBS market, and other investors became increasingly important as the underlying loan quality deteriorated. From 2001 to 2008, the GSEs purchased approximately $30 \%$ of subprime private label MBS and approximately $10 \%$ of Alt-A private label MBS. GSE purchases grew from 2001 to 2004 and then declined from 2004 to $2008 .^{200}$ As previously noted, the worst performing loans were originated in 2004 to 2007. In 2004 to 2006, overall subprime and Alt-A private label MBS volume increased, ${ }^{201}$ meaning that many other investors stepped up their purchase activity at the worst possible time, providing funding as the GSEs withdrew.

Although the GSEs reduced their purchase activity as the quality of the underlying collateral deteriorated, their policy shift may have had less to do with investment acumen than with regulatory pressure following an accounting scandal. ${ }^{202}$ Notwithstanding their portfolio losses, overall GSE loan delinquency rates are still substantially below those of most other market participants. ${ }^{203}$

\section{DodD-Frank Regulation May Not Be Enough to Prevent ANother CRISIS}

Theoretically, the government could protect taxpayers from another race to the bottom in a fragmented, competitive mortgage securitization market by implementing strong, uniform underwriting and compensation regulations and funding a powerful enforcement agency. In practice, recent regulatory changes constitute modest reforms backed by limited resources.

\section{A. High-Risk Loans Can Still Be Originated}

The Dodd-Frank Wall Street Reform and Consumer Protection Act ("DoddFrank") includes reforms that move the U.S. mortgage market toward more standardized minimum underwriting and documentation standards. Under DoddFrank, mortgage lenders must evaluate whether a prospective borrower is likely to be able to repay the mortgage and only originate the mortgage if the borrower is likely to repay. ${ }^{204}$ The bases for this determination must be objective factors such as

200. FCIC REPORT, supra note 74, at 124 fig.7.3. GSE subprime MBS purchases peaked at slightly below $40 \%$ in 2003 to 2004 , and dropped to closer to $25 \%$ by 2006 to 2007 . Id . GSE Alt-A MBS purchases peaked around 25\% in 2004 and declined to around 5\% by 2006 to 2007. Id.

201. Id.

202. According to the FCIC, the GSEs' pullback from private label MBS purchases was related to increased scrutiny and pressure they faced following accounting scandals. According to their regulator, the GSEs manipulated their financial reporting in the late 1990s and early 2000 s to increase payments to senior executives under incentive compensation plans. FCIC REPORT, supra note 74, at 122-23, 180, 310-11. For a summary of the accounting scandals, see Reiss, supra note 169, at 1035-39.

203. See supra Figure 11.

204. 15 U.S.C. $\S 1639$ c(a)(1) (Supp. IV 2011) (“[N]o creditor may make a residential mortgage loan unless the creditor makes a reasonable and good faith determination based on verified and documented information that, at the time the loan is consummated, the 
credit history, current income, expected income, current obligations, debt-toincome ratio, employment status, and other measures of financial resources. ${ }^{205}$ Income must be verified through $\mathrm{W}-2 \mathrm{~s}$, tax returns, payroll receipts, or financial institution records. ${ }^{206}$

These reforms are a step in the right direction, but they may not go far enough: the statute itself includes exceptions which can be exploited; detailed rulemaking is delegated to the Consumer Financial Protection Bureau (CFPB), a regulatory agency with huge responsibilities and limited resources; and enforcement built around consumer protection may not adequately protect the interests of taxpayers.

A major limitation of Dodd-Frank is that it does not standardize underwriting criteria per se, but instead provides a list of factors that originators should consider and documentation that they should collect. Detailed rulemaking is delegated to the CFPB.

Dodd-Frank establishes a two-tiered origination market in which more restrictive, detailed rules are reserved for "qualified residential mortgages" (QRMs). The primary advantage to originators of QRMs is that they are exempt from risk retention requirements of at least $5 \%$. In other words, originators and securitizers need only be concerned about more restrictive QRM rules if they are unwilling to retain a small fraction of the mortgages they originate.

A full discussion of QRM rules is beyond the scope of this Article, but minimal risk retention requirements may not fundamentally alter the economic rationale for issuing and then securitizing risky mortgages. Though more restrictive, "qualified mortgages" can still include risky features such as adjustable interest rates and, under certain circumstances, interest-only or negative amortization loans. ${ }^{207}$

\section{B. Compensation Can Still Create Perverse Incentives}

Many scholars have argued that compensation schemes for financial professionals contributed to the financial crisis because they established asymmetric, equity-like payoffs (high upside for success, limited downside for failure), prioritized short-term financial results over more reliable, long-term measures of value-creation, and thereby incentivized excessive risk taking. ${ }^{208}$ These

consumer has a reasonable ability to repay the loan, according to its terms, and all applicable taxes, insurance ... and assessments.").

205. Id. $\S 1639 \mathrm{c}(\mathrm{a})(3)$.

206. There is an exception to the income verification requirement for loans made, guaranteed, or insured by federal departments or agencies. Id. $\S 1639$ c(a)(4). It is unclear why loans explicitly backed by taxpayers are not subject to the same stringent income verification requirements as other loans.

207. 15 U.S.C. $\S 780-11$ (Supp. IV 2011).

208. See Patrick Bolton, Hamid Mehran \& Joel D. Shapiro, Fed. Reserve Bank of N.Y., EXECUTIVE COMPENSATION AND RISK TAKING (2010) (arguing that executive compensation based in part on debt prices will reduce risk for financial institutions); Lucian A. Bebchuk, Alma Cohen \& Holger Spamann, The Wages of Failure: Executive Compensation at Bear Stearns and Lehman 2000-2008, 27 YALE J. ON REG. 257 (2010) (reporting that the top five executives at two failed U.S. financial firms, Bear Stearns and Lehman Brothers, were able to cash out large amounts of bonus compensation that was not clawed back when the firms failed, were able to sell large amounts of equity prior to their firms' collapse, and became substantially wealthier during the 2000 to 2008 period); Lucian A. Bebchuk \& Jesse M. Fried, Paying for Long-Term Performance, 158 U. PA. L. REV. 1915 
scholars' recommended reforms - compensation tied to long-term performance, less equity, and more debt-like compensation - are not mandated by DoddFrank. ${ }^{209}$ Because financial institutions can still offer their equity holders and managers limited liability, high leverage, and huge upside potential, a high-risk strategy can still benefit shareholders and managers by transferring most of the downside risk to investors and much of the rest to taxpayers.

Dodd-Frank also does not prevent originators from again using their compensation schemes to emphasize quantity of mortgages over quality of mortgages. Dodd-Frank does not prohibit originators from compensating loan officers based on the volume of loans they produce or how readily those loans can be sold. ${ }^{210}$

\section{Regulators Remain Vulnerable and Underfunded}

Dodd-Frank's effectiveness may also be limited by its fragmented enforcement mechanisms. The principal rulemaking agency, the CFPB, cannot enforce its rules against depository institutions with less than $\$ 10$ billion in assets and must instead rely on those institutions' prudential regulators. ${ }^{211}$ Because there are many different prudential regulators, the door remains open for uneven enforcement and regulatory

(2010) (discussing implementation challenges for incentive-based pay in light of hedging opportunities available to executives); Lucian A. Bebchuk \& Holger Spamann, Regulating Bankers' Pay, 98 GeO. L.J. 247 (2010); Rüdiger Fahlenbrach \& René M. Stulz, Bank CEO Incentives and the Credit Crisis, 99 J. FIN. ECON. 11 (2011) (finding some evidence that banks with CEOs whose incentives were better aligned with the interests of shareholders performed worse during the financial crisis and no evidence that they performed better); Kristin N. Johnson, Addressing Gaps in the Dodd-Frank Act: Directors' Risk Management Oversight Obligations, 45 U. Mich. J.L. REFoRM 55, 95 (2011); Rangarajan K. Sundaram \& David L. Yermack, Pay Me Later: Inside Debt and Its Role in Managerial Compensation, 62 J. FIN. 1551 (2007) (reporting that CEOs with high debt incentives manage firms conservatively); Frederick Tung, Pay for Banker Performance: Structuring Executive Compensation for Risk Regulation, 105 Nw. U. L. REV. 1205 (2011) (reviewing the role of equity compensation in encouraging risk taking and arguing that financial managers should be compensated with subordinated debt instead of equity to make them more cautious); Divya Anantharaman, Vivian W. Fang \& Guojin Gong, Inside Debt and the Design of Corporate Debt Contracts, Paper Presented at Fifth Singapore International Conference on Finance (Jan. 19, 2011), available at http://ssrn.com/abstract=1743634 (providing empirical evidence that creditors believe that it is safer to lend to firms in which managers hold a higher ratio of debt-to-equity than the firm as a whole); Sanjai Bhagat \& Roberta Romano, Reforming Executive Compensation: Simplicity, Transparency, and Committing to the LongTerm (Yale Law Sch. John M. Olin Ctr. for Studies in Law, Econ., \& Pub. Policy, Research Paper No. 393, 2009), available at http://ssrn.com/abstract=1506742 (arguing for restricted stock compensation); Frederick Tung \& Xue Wang, Bank CEOs, Inside Debt Compensation, and the Global Financial Crisis (Bos. Univ. Sch. of Law, Working Paper No. 11-49, 2011), available at http://www.bu.edu/law/faculty/scholarship/workingpapers/2011.html (providing empirical evidence that inside debt compensation of CEOs is associated with better performance and less risk taking during the financial crisis).

209. Dodd-Frank's compensation provisions generally rely on greater disclosure to shareholders and greater shareholder influence. 15 U.S.C. $\S 78 n-1$ (2006). Because shareholders should rationally prefer high-risk strategies, Dodd-Frank's approach is unlikely to result in compensation schemes that reduce managers' incentives to take risks.

210. 15 U.S.C. $\S 1639$ c.

211. 12 U.S.C. $\$ 5516(d)$. 
arbitrage. By contrast, to the extent that originators depend on the GSEs for financing, originators will face largely standard, uniform risk management practices and relatively swift penalties for noncompliance.

The effectiveness of the CFPB will also likely be hampered by continued efforts to defund it and reduce its ability to operate independent of politics. ${ }^{212}$ Given the political influence of the financial services industry, ${ }^{213}$ it seems unlikely that the CFPB could effectively regulate underwriting if it were subject to annual appropriations by Congress. ${ }^{214}$

212. The CFPB is currently more insulated from political influence than most regulators. Under Section 1017 of the Dodd-Frank Act, codified at 12 U.S.C. $\S 5947$, the CFPB's annual budget is not determined through congressional appropriation but is capped as a percentage of the Federal Reserve's operating expenses. The cap is $10 \%$ in $2011,11 \%$ in 2012 , and $12 \%$ in 2013 . The funding mechanism also provides for adjustments for inflation. 12 U.S.C. $\S 5947(a)(1)-(2)$.

Some Republican members of Congress have sought to repeal the provisions of DoddFrank that protect the CFPB's independence, to subject it to congressional appropriations, and to block the appointment of a director if the CFPB is not subject to annual appropriations and other measures to reduce its authority. See Phil Mattingly \& Richard Rubin, Budget Cuts for Consumer Bureau, IRS Proposed by Republicans, BloOMBERG.COM (June 15, 2011, 4:31 PM), http://www.bloomberg.com/news/2011-06-15/budget-cuts-for-consumer-bureau-irs-proposedby-republicans.html (reporting that House Republicans proposed to cut the CFPB's budget to $\$ 200$ million per year, down from the $\$ 500$ million envisioned in Dodd-Frank, and to subject the agency to annual appropriations); see also Jessica Holzer, House Panel Targets Consumer Bureau, SEC Budgets, WSJ.cOM (June 23, 2011, 6:01 PM), http://online.wsj.com/article/SB10001424052702303339904576404102094921400.html (reporting that Republican law makers shepherded bills through the House Appropriations Committee that would shave hundreds of millions of dollars from the SEC and CFPB's budgets).

213. According to the Center for Responsive Politics, the finance, insurance, and real estate industries have spent over $\$ 4.8$ billion in lobbying from 1998 to 2011 - more than any sector except healthcare. Lobbying: Ranked Sectors, CENTER fOR ResPonsive Politics, http://www.opensecrets.org/lobby/top.php?indexType=c.

214. Lender lobbying is associated with riskier underwriting practices. See supra note 196 and accompanying text. Consumer protection regulation may help maintain financial system stability. See Kathleen C. Engel \& Patricia A. McCoy, Turning a Blind Eye: Wall Street Finance of Predatory Lending, 75 FordHAM L. REV. 2039, 2041-42 (2007); Erik F. Gerding, The Subprime Crisis and the Link Between Consumer Financial Protection and Systemic Risk, 4 FLA. INT'L U.L. REV. 435 (2009) (arguing that consumer protection would promote stability by reducing the number of defaults, making defaults more predictable, and making defaults less correlated with one another); McCoy et al., supra note 90, at 1348-57 (discussing federal preemption of state anti-predatory lending laws); Alan White, Carolina Reid, Lei Ding \& Roberto G. Quercia, The Impact of State Anti-Predatory Lending Laws on the Foreclosure Crisis, 21 CoRnell J.L. \& PUB. POL'y 247 (2011) (providing empirical evidence that state anti-predatory lending laws reduced the likelihood of serious mortgage delinquency by $13 \%)$.

For the broader intellectual case for a politically independent regulator to ensure the safety of consumer financial services products, see Oren Bar-Gill \& Elizabeth Warren, Making Credit Safer, 157 U. PA. L. REV. 1 (2008); Ann Graham, The Consumer Financial Protection Agency: Love It or Hate It, U.S. Financial Regulation Needs It, 55 VILL. L. ReV. 603 (2011); Adam J. Levitin, The Consumer Financial Protection Agency (Georgetown Law Faculty Working Papers, Research Paper No. 1447082, 2009), available at http://ssrn.com/abstract=1447082; Sharon L. Tennyson, Analyzing the Role of a Consumer Financial Protection Agency (Ind. State 
The rationale claimed by members of Congress who wish to defund the CFPBbudgetary necessity ${ }^{215}$ — would be more difficult to apply to the risk management function of a government-owned enterprise that was profitable and entirely selffunding. The CFPB's budget-likely a few hundred million dollars spread across many consumer product markets - pales in comparison to the resources the GSEs can devote to the residential mortgage finance market. For example, in 2010, the GSEs' administrative expenditures were over four billion dollars, focused entirely on managing the residential mortgage finance market. ${ }^{216}$

\section{CONCLUSION}

Recent experience in the U.S. mortgage securitization market illustrates how competition between financial institutions seeking market share can destabilize financial systems and ultimately result in losses to taxpayers. Mortgage underwriting and loan performance generally improved from 2000 to 2003, during a period of GSE dominance, and dramatically deteriorated from 2004 to 2007 as originators consolidated and intense competition from smaller, private securitizers reduced GSE influence. Although the GSEs appear to have relaxed their underwriting standards somewhat during this latter period, on the whole GSE loans remained far less default prone than those of smaller financial institutions, and the recent period of restored GSE dominance has been one of relatively pristine underwriting. ${ }^{217}$

Competition can undermine originators' and securitizers' ability to effectively screen loans and securitizers' ability to monitor and discipline originators. Profitdriven institutions that do not wish to compete by reducing their revenues and profit margins can instead compete by taking on more risk, ultimately keeping most upside while transferring most downside risk to taxpayers. Competition is most dangerous when financial institutions serve underwriting functions-as mortgage

Univ. Networks Fin. Inst., Policy Brief 2009-PB-13, 2009), available at www.human.cornell.edu/pam/outreach/loader.cfm?csModule=security/getfile\&PageID=50052.

Critics of consumer protection regulation have focused on the possibility that such regulation might increase compliance costs for private financial institutions and that consumer credit might become more expensive or less available. See David S. Evans \& Joshua D. Wright, The Effect of the Consumer Financial Protection Agency Act of 2009 on Consumer Credit, 22 Loy. Consumer L. Rev. 277 (2010). But see Adam J. Levitin, A Critique of Evans and Wright's Study of the Consumer Financial Protection Agency Act (Georgetown Univ. Law Ctr. Bus., Econ. \& Regulatory Policy Working Paper Series, Research Paper No. 1492471, 2009), available at http://ssrn.com/abstract=1492471.

215. See Holzer, supra note 212 ("Rep. Jo Ann Emerson (R., Mo.) acknowledged that some Republicans want to hobble the agency created by the Dodd-Frank financial law by depriving it of funds. But she argued that ... 'With the debt that we've got right now, \$200 million is more than ample, more than fair for an agency that isn't required to report to us ... .'”). If fully funded at $\$ 500$ million, the CFPB's budget would equal less than $0.02 \%$ of the federal government's \$3.8 trillion budget for 2011. See Office of Mgmt. \& Budget, BUdGET OF THE U.S. GOVERNMENT: FisCAL YEAR 2011, at 151 (2010).

216. 1 InSIDE MORTG. FIN., supra note 60, at 317 . While the GSEs do not spend their entire administrative budget monitoring originators and mortgage quality, it is probably a safe bet that they spend more than the CFPB could ever hope to spend.

217. Nick Timiraos \& Maurice Tamman, Tighter Lending Crimps Housing, WSJ.com (June 25, 2011), http://online.wsj.com/article/SB10001424052702304569504576405660006330644.html. 
originators and securitizers do - but may be less of a concern for institutions whose activities are purely administrative or transactional in nature.

Perhaps competition could be channeled toward purely administrative functions that do not critically affect risk management or underwriting decisions. ${ }^{218}$ Perhaps competition on underwriting could be made safer under a different, idealized regulatory regime ${ }^{219}$ or a different, idealized system of compensation for financial professionals. ${ }^{220}$ However, it is an act of great faith to assume that incremental and largely untested financial reforms have established that idealized system and removed the threat of another race to the bottom if full-fledged competition is restored.

While a system of suppressed competition may have its own flaws-perhaps mortgages would become more expensive, perhaps access to credit for marginal borrowers would be reduced - taxpayers would be safer. And to the extent that higher mortgage pricing results in higher profits and higher dividends to the Treasury - that is, if the government can capture the full upside of mortgage funding during profitable years, rather than taking only a minority of the upside through taxation and guarantee fees - profits could be used to repay the debt incurred during the most recent financial sector bailouts and to build reserves for future crises.

The Treasury's proposed approach - a gradual shrinking of the GSEs and FHA - could lead to a more fragmented, competitive, and dangerous securitization market in which for-profit institutions backed by implied government guarantees once again compete for market share and revenue.

The results of this analysis are by no means definitive, but they raise questions about the Treasury's assumptions and doubts about its proposals for reforming housing finance. At a minimum, more study should be undertaken before the Treasury moves forward with a program of radical reform. More traditional alternatives - such as a return to the concentrated, government-led market structure and conservative underwriting standards that prevailed from the mid-1940s to the late 1960s - should be considered in light of empirical evidence linking such structures to greater financial stability in the U.S. residential mortgage market.

218. See FCIC REPORT, supra note 74, at 89 (describing how one large mortgage originator used specialization to cut costs and sell mortgages for $0.55 \%$ less than competing firms). Although this particular firm was engaged in fraudulent practices, efficiency is possible without fraud. Id. at 12-14, 89 ("For decades, a version of the originate-to-distribute model produced safe mortgages. Fannie and Freddie had been buying prime, conforming mortgages since the 1970 s, protected by strict underwriting standards.").

219. See Org. For ECON. Co-OPERATION \& Dev., supra note 49, at 27 (arguing that although recent financial crises in the United States, Scandinavia, and Asia "suggest that liberalisation and competition contribute to financial crises ... the relationship between competition and stability depends on the regulatory framework"); Andrea Beltratti \& René M. Stulz, Why Did Some Banks Perform Better During the Credit Crisis? A Cross-Country Study of the Impact of Governance and Regulation (Nat'l Bureau of Econ. Research Paper Series, Working Paper 15180, 2009) (providing empirical evidence that banks in countries with more independent regulators and higher capital requirements performed better than other banks during the financial crisis); supra note 214 (discussing a possible link between consumer protection and financial system stability).

220. See supra note 208. 
Instead of entertaining radical proposals for privatization, the federal government could focus on improving the operational efficiency of the many mortgage funding agencies that it now controls, reducing risks and boosting profits for taxpayers. There are now at least five government-controlled agencies that play a role in guaranteeing and funding mortgages - the FHA, the VA, Ginnie Mae, Fannie Mae, and Freddie Mac.

Greater efficiency, economies of scale, and increased market power could be realized by merging these entities' mortgage operations into a single state-owned enterprise, streamlining redundant functions and reducing costs, integrating information systems and boosting loan sampling rates to better monitor loan originators, and analyzing the vast collective repository of ex post loan performance data to improve ex ante underwriting capabilities.

Greater size and consolidated funding would enhance the ability to monitor originators, discipline those who originate risky loans, and maintain high, uniform underwritings standards. These improvements could be reinforced by granting the newly dedicated mortgage agency the exclusive right to securitize mortgages.

The government could also use the size and market power of a single stateowned mortgage enterprise to institute changes to mortgage industry compensation that could better align the interests of its employees with those of taxpayers. These changes could include tying a substantial portion of each individual employee's compensation to the long-term performance of mortgage loans that the employee approves.

There is a long-term risk, to be sure, of a state-owned enterprise succumbing to political pressure - just as there are risks of regulatory capture. It may be prudent for the government to commit, through legislation, to prioritize sound underwriting and long-term profitability for the benefit of taxpayers over targeted subsidies for favored political groups.

Perhaps risks could also be mitigated through legislation granting political independence as long as certain benchmarks of operational efficiency are met. There are many examples of successful independent agencies and profitable stateowned enterprises, such as the Government Accountability Office, ${ }^{221}$ the Port Authority of New York and New Jersey, ${ }^{222}$ and the Triborough Bridge and Tunnel

221. The U.S. Government Accountability Office (GAO) was established in 1921 as an independent nonpartisan agency to investigate and improve the performance of federal government programs. According to the GAO, it has saved taxpayers $\$ 45.7$ billion, an $\$ 81$ return for every dollar invested in the GAO. About GAO, U.S. Gov'T ACCOUNTABILITY OFF., http://www.gao.gov/about/; GAO at a Glance, U.S. Gov'T ACCOUNTABILITY OfF., http://www.gao.gov/about/gglance.html.

222. The Port Authority is a self-sustaining agency that builds, operates, and maintains systemically important transportation infrastructure-including airports, seaports, bridges, tunnels, a bus terminal, and a rail line-for one of the largest and most prosperous metropolitan areas in the world. Overview of Facilities and Services, PORT AUTHORITY N.Y. \& NEW JERSEY, http://www.panynj.gov/about/facilities-services.html. It supports itself through use fees, not tax revenue, and can only borrow money against its own revenues and assets, not those of the state. Id. It has survived earthquakes, hurricanes, and terrorist attacks. It has a high credit rating and the data suggests that it is financially sound. Id. From 2002 to 2011 , net assets increased from $\$ 5.9$ to $\$ 11.7$ billion and leverage ratios remained stable. Port Authority of N.Y. \& N.J., Financial Statements AND APPEnded Notes Year 2003, 
Authority, ${ }^{223}$ most of which were founded during the heyday of the progressive era and have lasted nearly a century.

Rather than rely solely on regulators with limited budgets, political vulnerability, and limited control over the financial institutions they regulate, the government could "regulate" the mortgage market directly by establishing corporate underwriting policy at a fully government owned and controlled mortgage funding agency. Such "regulations"- backed by trillions of dollars in purchasing power-are at least as likely to be effective as threats of sanctions from regulatory agencies, and could reinforce such agencies' efforts to maintain prudent underwriting and protect taxpayers.

If a state-owned enterprise proved to be loss-making over the long term and an unacceptable drain on taxpayer resources - and it would have to be very inefficient to rival the damage to public finance from private financial institutions' risk taking activities during the recent crisis - privatization would always remain an option. Freely ceding market share to for-profit competitors - as a number of advocates of privatization propose - is unlikely to yield much in the way of returns for taxpayers. However, selling exclusive regional mortgage securitization licenses or an exclusive national license and the GSEs' infrastructure to the highest bidder (and regulating underwriting and pricing at the private monopoly level thereby established) could be considered as an option that might better protect taxpayer interests while maintaining a stable, concentrated market structure.

Given the GSEs relatively strong record on whole loan purchases, dominant secondary market position, and current de facto ownership by the government, they could be reformed into a powerful, permanent vehicle for long-term stabilization of the mortgage market and taxpayer protection.

at 4-5 (2004); Port Authority of N.Y. \& N.J., Financial Statements And Appended Notes FOR THE YeAR ENDED DeCEMBER 31, 2011, at 6 (2012).

223. The Triborough Bridge and Tunnel Authority (TBTA) and its precursors constructed, operated, and maintained bridges and tunnels that connect the boroughs of New York City. The TBTA has long generated a surplus from toll revenue, which was used to fund construction of public beaches and parks and a convention center. After the TBTA was merged with the Metropolitan Transit Authority (MTA) in 1968, TBTA surplus was used to subsidize mass transit. The TBTA is a cofounder of E-ZPass, a wireless electronic toll collection system used in 14 states. See Sam Roberts, Reappraising a Landmark Bridge, and the Visionary Behind It, N.Y. TIMES, July 11, 2006, at B6; Welcome to MTA Bridges and Tunnels, Metro. Transit Auth., http://www.mta.info/bandt/html/btintro.html. 